\title{
VEGETATION TRENDS IN WHITEHORSE YUKON, 1984 TO 2009
}

\author{
By
}

\author{
Dexter J. Kotylak \\ Honours BSc, University of British Columbia, Kelowna, British Columbia, Canada 2013
}

\author{
A thesis presented to Ryerson University \\ in partial fulfillment of the requirements for the degree of \\ Master of Applied Science \\ in the Program of \\ Environmental Applied Science and Management
}

Toronto, Ontario, Canada, 2018

(C) Dexter J. Kotylak, 2018 


\section{Author's Declaration}

I hereby declare that I am the sole author of this thesis. This is a true copy of the thesis, including any required final revisions, as accepted by my examiners. I authorize Ryerson University to lend this thesis to other institutions or individuals for the purpose of scholarly research. I further authorize Ryerson University to reproduce this thesis by photocopying or by other means, in total or in part, at the request of other institutions or individuals for the purpose of scholarly research. I understand that my thesis may be made electronically available to the public. 


\begin{abstract}
VEGETATION TRENDS IN WHITEHORSE YUKON, 1984 TO 2009
\end{abstract}

\author{
Dexter J. Kotylak \\ Master of Applied Science, 2018 \\ Environment Applied Science and Management \\ Ryerson University
}

To assess temporal greenness trends at the landscape scale for Whitehorse, Yukon (417 $\mathrm{km}^{2}$ ), this study derived a Landsat normalized difference vegetation index (NDVI) time-series from 1984 to 2009. Using a greenest annual pixel approach, NDVI trend analysis revealed that $37 \%$ of studied area had significant greening $(\mathrm{p}<0.05)$ and that only $1 \%$ of the studied land area had significant browning. Yearly mean NDVI values declined in drought years and increased in years with greater precipitation. Greening pixels were most prevalent in white spruce (Picea glauca) and subalpine fir (Abies lasiocarpa) dominant forests, suggesting that increased amounts of precipitation and rising temperatures have benefited both species and associated shrub communities. Forests where trembling aspen (Populas tremuloides) are dominant displayed the least greening, which may be explained by the proliferation of aspen serpentine leaf miner (Phyllocnistis populiella), and drought related die-back on south-facing slopes that have become warmer across the study period. 


\section{Co-Authorship}

The following list provides the names and institutions of the people who contributed to the manuscript that is the basis for this thesis:

Kotylak, D.J. ${ }^{1}$, Millward, A.A. ${ }^{2}$. (2018). Vegetation Trends in Whitehorse Yukon, 1984 to 2009.

1 Dexter J. Kotylak: Candidate

2 Andrew A. Millward: Associate Professor, Department of Geography and Environmental Studies, Ryerson University. Principal Investigator, Ryerson University Urban Forest Research and Ecological Disturbance (UFRED) Group

Authorship of anticipated publication is as follows: Kotylak, D. J., and Millward, A. A.

Vegetation Trends in Whitehorse Yukon, 1984 to 2009. (To be submitted).

The candidate is the primary author of the thesis and manuscript. Author 2 is the candidate's supervisor who contributed to the experimental design development, provided guidance on analysis methods, and reviewed and edited the manuscript. 


\section{Acknowledgements}

First, I would like to acknowledge Dr. Andrew Millward for his guidance and support throughout the research and writing process. Dr. Millward inspired me to explore my own research questions and with his knowledge of remote sensing, provided invaluable contributions into the design and methodology of this work. Thank you to my defense committee members Dr. Stephanie Melles (Department of Chemistry and Biology) and Dr. David Atkinson (Department of Geography and Environmental Studies) for providing comments and insight into the thesis manuscript. I would also like to thank Dr. Michael Wulder (Natural Resources Canada, Canadian Forest Service) for his contributions to the methodology of this study.

I express gratitude to Ryerson University's Yeates School of Graduate Studies for financially supporting me with the Ryerson Graduate Fellowship and TA positions.

In the background, I owe many thanks to my parents Don and Roberta, and my brother Dustin for always believing in me. Most of all, I would like to thank my wife, Larissa, for the continued love and encouragement. I could not have done this without you. 


\section{Table of Contents}

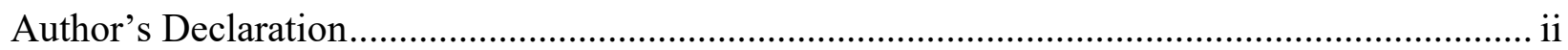

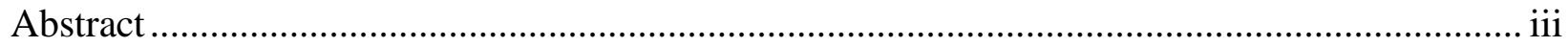

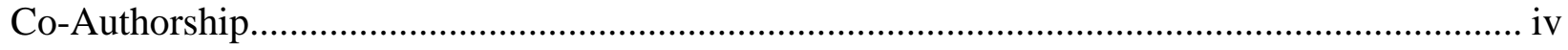

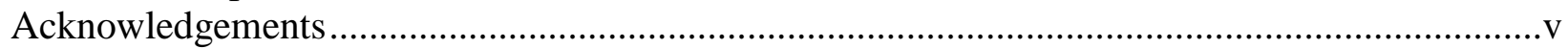

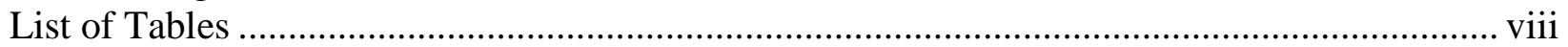

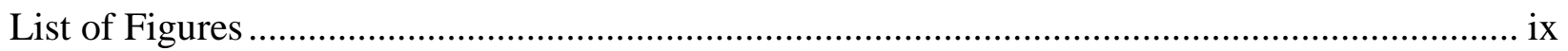

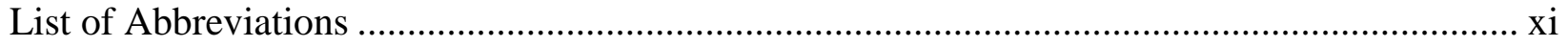

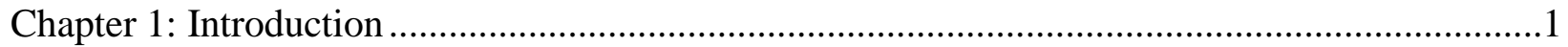

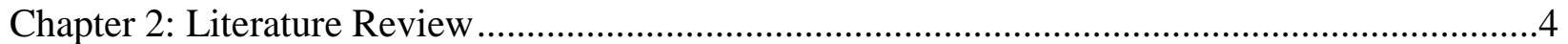

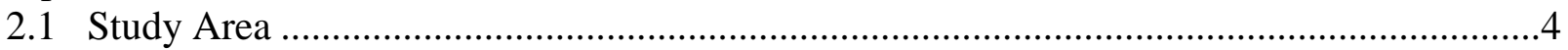

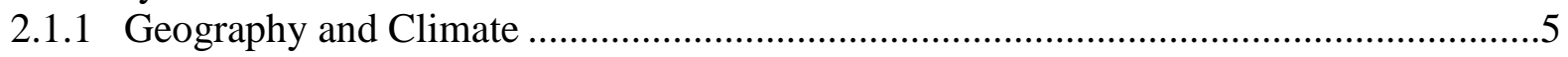

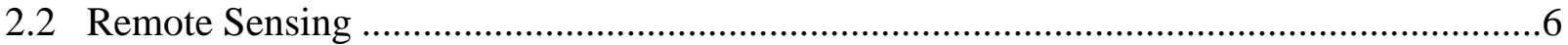

2.2.1 Early Remote Sensing ...................................................................................

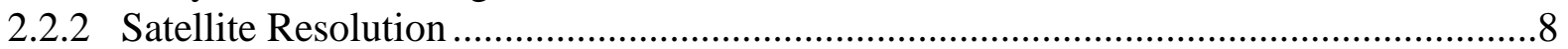

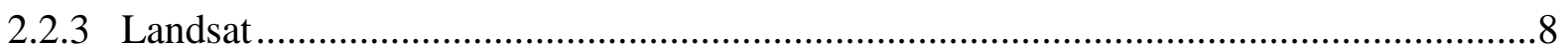

2.2.4 Vegetation Indices ............................................................................................11

2.2.4.1 Ratio Indices: Normalized Difference Vegetation Index (NDVI) .................11

2.2.4.2 Tasseled Cap Transformation ...................................................................13

2.2.4.3 Using Multiple Vegetation Indices (VI) .......................................................15

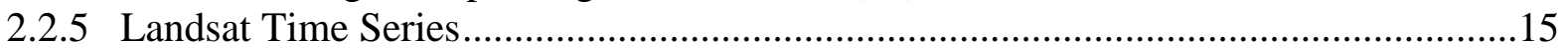

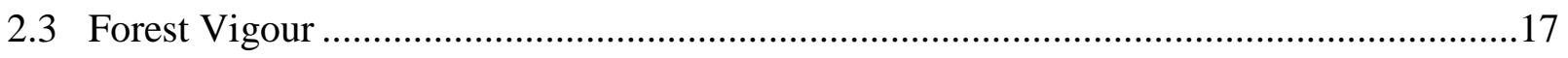

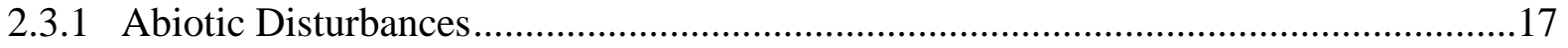

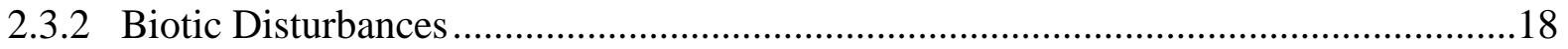

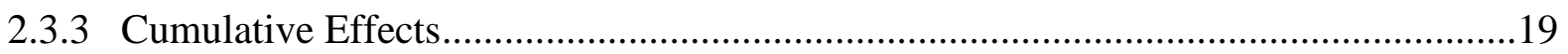

2.3.4 Regional Scale Forest Vigour …………….......................................................19

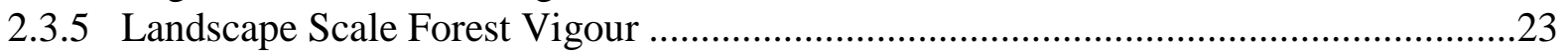

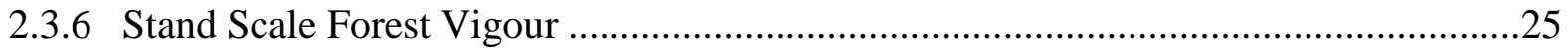

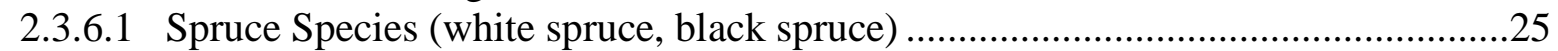

2.3.6.2 Deciduous Species (trembling aspen, balsam poplar) ……………………….......2

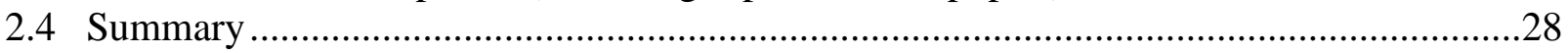

Chapter 3: Vegetation greenness trends in Whitehorse Yukon from 1984 to 2009 .....................29

3.1 Research Highlights ...............................................................................................29

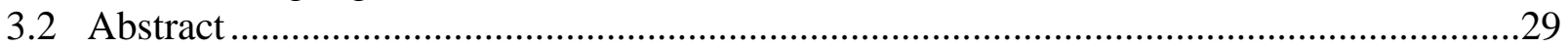

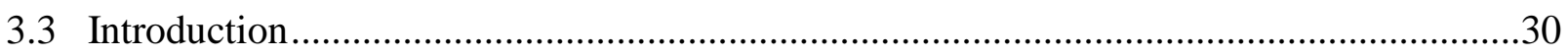

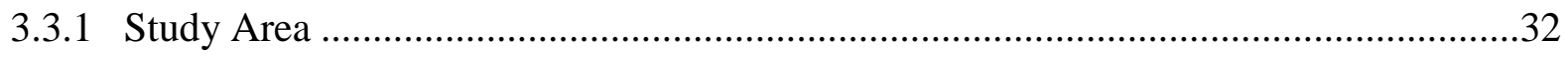

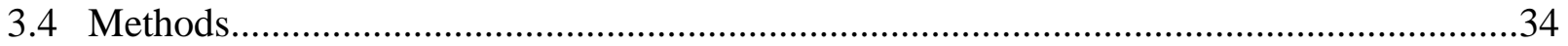

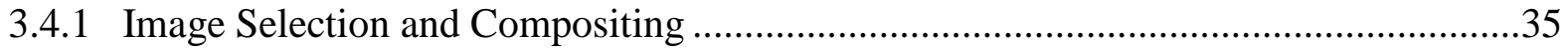

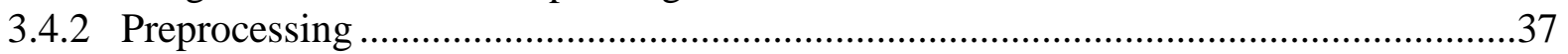

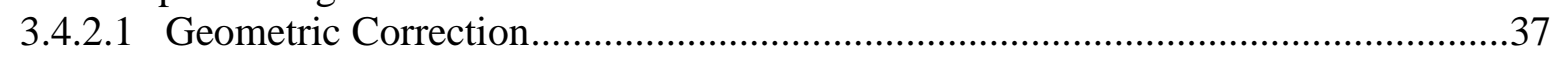

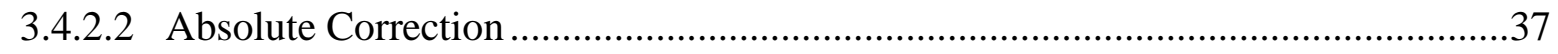

3.4.2.3 Relative Correction ......................................................................................38

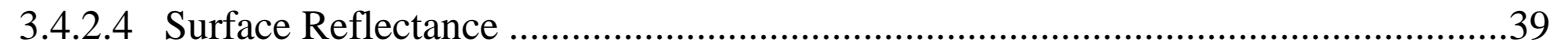

3.4.3 Preparation of Greenest Annual Image Composites ...................................................40

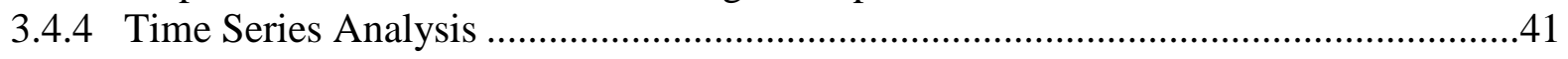




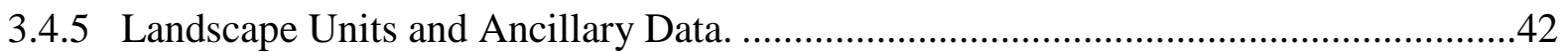

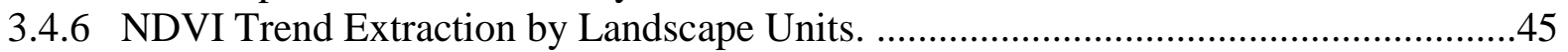

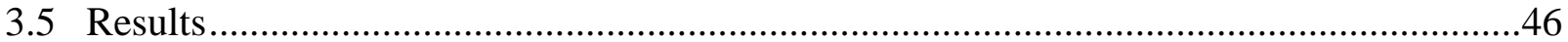

3.5.1 Greenest Annual Pixel Composites ..........................................................................46

3.5.2 Spatiotemporal Linear Trends for Whitehorse Study Area .........................................4

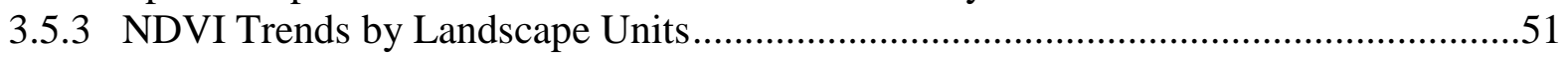

3.5.3.1 Pixel-wise NDVI Trends for Area Classes ……….............................................51

3.5.3.2 Linear Regression for Area Classes ..................................................................52

3.5.3.3 Pixel-wise NDVI Trends for Leading Species Classes...........................................55

3.5.3.4 Linear Regression for Leading Species Classes ....................................................56

3.5.3.5 Pixel-wise NDVI Trends for Management Strata …………………………......57

3.5.3.6 Linear Regression for Management Strata …………...........................................58

3.5.3.7 Pixel-wise NDVI Trends for Soil Moisture Regimes ............................................59

3.5.3.8 Linear Regression for Soil Moisture Regimes.................................................60

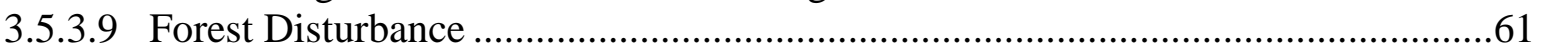

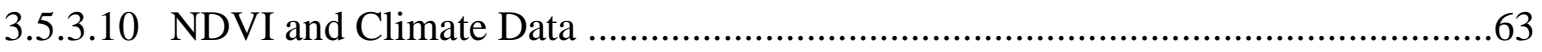

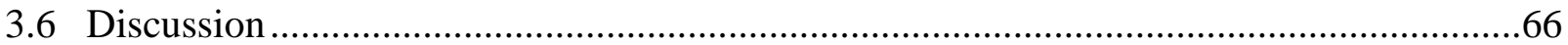

3.6.1 Regional NDVI Trends and the Influence of Climate .............................................68

3.6.2 Effects of Landscape Position on NDVI Trends ........................................................69

3.6.3 Effects of Aspect on NDVI Trends ...................................................................

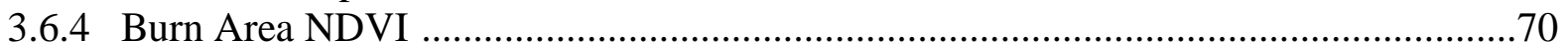

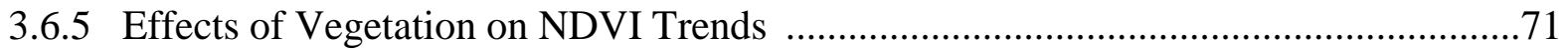

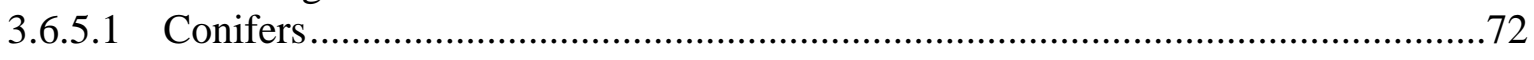

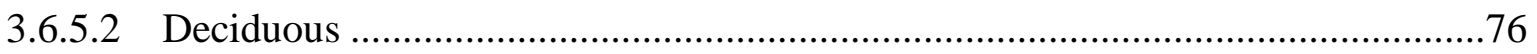

3.6.6 Effects of Soil Moisture Regime on NDVI Trends ..................................................78

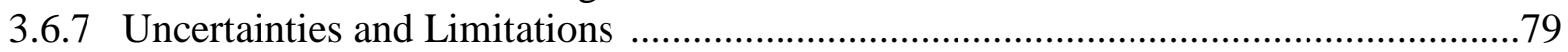

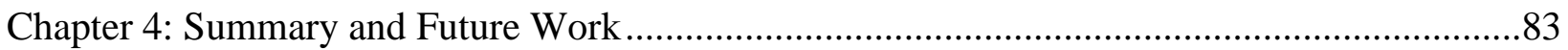

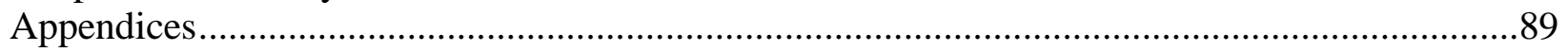

Appendix 1: Landscape position classes for Whitehorse, Yukon. ………………….................89

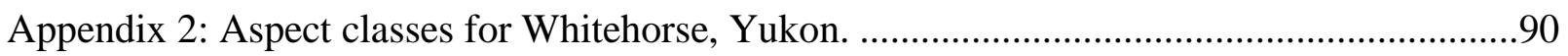

Appendix 3: Burn area classes for Whitehorse, Yukon..........................................................

Appendix 4: Leading species classes for Whitehorse, Yukon...................................................92

Appendix 5: Management strata for Whitehorse, Yukon........................................................93

Appendix 6: Soil moisture classes for Whitehorse, Yukon.......................................................94

Appendix 7: Landsat scenes used for greenest annual composites. ……………………..........95

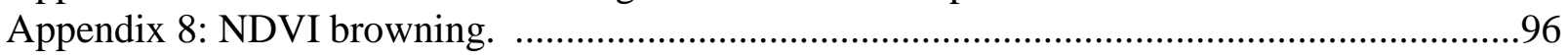

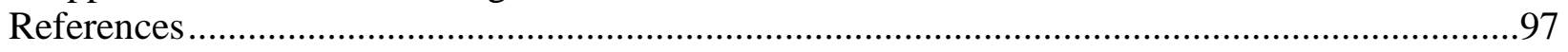




\section{List of Tables}

Table 2.1: Climate trends for Whitehorse, Yukon using non-parametric trend analysis. .6

Table 2.2: Landsat satellites and characteristics (Table source: http://landsat.usgs.gov).............10 Table 3.1: Climate trends for Whitehorse, Yukon using non-parametric trend analysis (Table after Hennessey and Striecker, 2011). .34

Table 3.2: Landscape unit area classes with associated descriptions. .....................................43

Table 3.3: Yukon government management strata. ........................................................4

Table 3.4: Soil moisture regime.

Table 3.5 Greenest annual composite scenes with satellite sensor used, proportion of study area available for analysis, and associated mean NDVI values.

Table 3.6: 1984 to 2009 linear regression results, by area class, for relationship between NDVI and year of image composite.

Table 3.7: 1984-2009 leading species description and linear regression findings for association with NDVI.

Table 3.8: 1984-2009 linear regression for NDVI within management strata. ..........................59

Table 3.9: 1984-2009 linear regression for NDVI according to soil moisture regime................61 Table 3.10: Aspen serpentine leaf miner damage area, and proportion of area affected according to leading species and management strata.

Table 3.11: Correlation matrix (Pearson's r) for leading species classes. All correlations are significant $(\mathrm{p}<0.05)$.

Table 4.1: Summary of NDVI trends across investigated landscape units from 1984 to 2009 for Whitehorse, Yukon (significance, $\mathrm{p}<0.05$ ). 


\section{List of Figures}

Figure 2.1: Yukon Territory with Whitehorse study area (magnification) Study area image from Landsat ETM scene.

Figure 2.2: NDVI calculation for healthy vegetation (left) and stressed vegetation (right).

Healthy vegetation absorbs incoming red light while reflecting infrared light. Stressed vegetation reflects more red light and less infrared light. (Diagram after: NASA, 2017).

Figure 2.3: Tasseled Cap Transformation (TCT): orthogonal transformation of multiple spectral

bands into three tasseled cap bands indicative of greenness, brightness and wetness..................14

Figure 3.1: Yukon Territory with Whitehorse study area (magnification) Study area image from

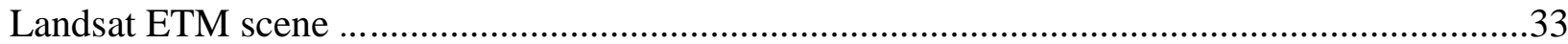

Figure 3.2: Diagram of data collection and processing approach showing the integration of

satellite date with local and regional environmental variables. ............................................35

Figure 3.3: Landsat levels of absolute radiometric correction (Figure after Young et al., 2017). 38

Figure 3.4: Box and whisker plots showing descriptive statistics for each annual NDVI

composite included in the time-series image stack for Whitehorse, Yukon.

Figure 3.5: Greening trends, as revealed using NDVI composite images, for Whitehorse, Yukon

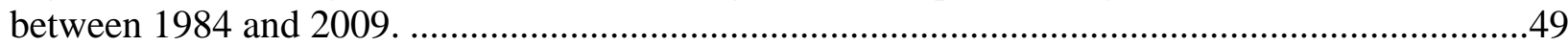

Figure 3.6: Significance of greening trends, for Whitehorse, Yukon between 1984 and 2009.....50

Figure 3.7: Proportion of pixels, within each area class, having significant NDVI trends.

Proportions were calculated for percentage of greening or browning pixels located in individual landscape units and percentage of greening or browning pixels located in individual landscape

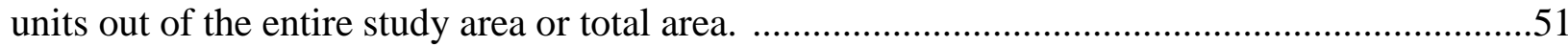

Figure 3.8: 1984-2009 NDVI trend within the Whitehorse study area...................................52

Figure 3.9: 1984-2009 NDVI trend within landscape position classes: subalpine, upland and

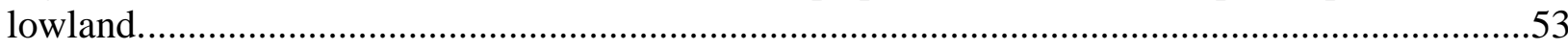

Figure 3.10: 1984-2009 NDVI trend associated with landscape aspect classes........................54

Figure 3.11: 1984-2009 NDVI trend within burn area classes. ...........................................55

Figure 3.12: Percentage of pixels with significant NDVI trends across leading species classes. Percentages were calculated for percentage of pixels by individual landscape units and by total

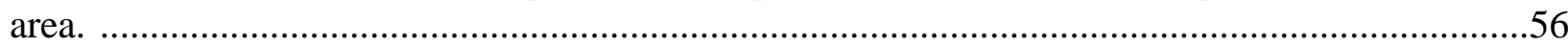

Figure 3.13: Percentage of pixels with significant NDVI trends across management strata. Percentages were calculated for percentage of pixels by individual landscape units and by total

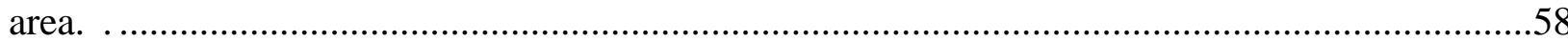

Figure 3.14: Percentage of pixels with significant NDVI trends across soil moisture regime. Percentages were calculated for percentage of pixels by individual landscape units and by total area.

Figure 3.15: Satellite images and air photos depicting aspen serpentine leaf miner damage (Yukon Government aerial overview survey polygons outlined in black). From left to right 1984 NDVI composite (a), 2009 NDVI composite (b), 2009 air photo (c), 2009 air photo with significant pixel browning overlay (d).

Figure 3.16: Cubic spline fitted through mean annual NDVI versus year for the Whitehorse study

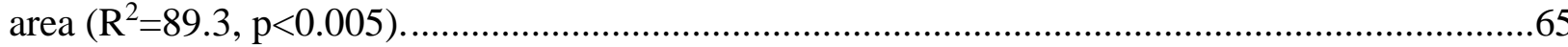

Figure 3.17: Whitehorse July mean temperature $\left(\mathrm{C}^{\circ}\right)$ and total May to August precipitation (mm), 1984-2009 (data from Whitehorse International Airport). 
Figure 3.18: Mean June-August temperature versus total precipitation from 1942-2009.Drought years in time series indicated by red dots. 


\section{List of Abbreviations}

AVHRR

API

BAP

DEM

ETM+

EVI

fAPAR

GIMMS

GEE

IDE

TM

LAI

LTS

LEDAPS

LIDAR

MODIS

NDVI

NIR

PIF

SWNIR

TCT
Advanced Very High Resolution Radiometer

Application Programming Interface

Best Available Pixel

Digital Elevation Model

Enhanced Thematic Mapper Plus

Enhanced Vegetation Index

Fraction of Absorbed Photosynthetically Active

Radiation

Global Inventory Modeling and Mapping Studies

Google Earth Engine

Interactive Development Environment

Thematic Mapper

Leaf Area Index

Landsat Time Series

Landsat Ecosystem Disturbance Adaptive Processing

Light Detection and Ranging

Moderate-resolution Imaging Spectroradiometer

Normalized Difference Vegetation Index

Near-Infrared

Pseudo Invariant Feature

Shortwave Near-Infrared

Tasseled Cap Transformation 
DI

USGS

VI
Disturbance Index

United States Geological Survey

Vegetation Index 


\section{Chapter 1: Introduction}

Over the past 60 years the Earth's surface has warmed by approximately $0.12^{\circ} \mathrm{C}$, per decade (Stocker et al., 2013). The boreal forests of northwest Canada and Alaska have experienced the most pronounced climate warming compared to other forest regions in North America (Trenberth et al., 2007). Climate change has already impacted the boreal forest. It has

been linked to changes in vegetation phenology and productivity (Beck and Goetz, 2011), as well as to an increase in the frequency and magnitude of wildfires (Flannigan et al., 2006), insect and disease attack (Kurz et al., 2008; Sturrock et al., 2011), and extreme weather events (drought, heavy rain, ice storms and heat damage) (Allen et al., 2010). Generally, these effects are expected to increase with anticipated climate change projections (Price et al., 2013). Disturbance regimes, such as wildfire and insect outbreaks, facilitate regeneration and regrowth of boreal ecosystems. However, evidence suggests that pervasive influences of climate change overwhelm the boreal forests' natural adaptive capacity to regenerate, negatively affecting overall forest health (Gauthier et al., 2014). In contrast, areas experiencing increased precipitation and temperatures are associated with increased productivity in central Canada (Slayback et al., 2003; Tucker et al., 2005) and the Arctic tundra (Myneni et al., 1997; Jia et al., 2003; Goetz et al., 2005). Satellite-derived measurements of forest vigour or vegetation 'greenness' can act as a metric for forest health (Pettorelli, 2013). Healthy forest stands are represented by more 'greenness' than stressed or disturbed forest stands. Given the spatial extent and remoteness of Canada's boreal forest, the application of remote sensing delivers a method to monitor and investigate temporal and spatial trends in boreal forest greenness because of influences from climate and more localized ecological disturbance. 
Whitehorse, Yukon has the highest human population within the territory and is predominantly covered by boreal forest. Being one of the largest populations north of $60^{\circ}$ in Canada, its population will be one of the first to experience high-latitude boreal forest changes. This study used remote sensing to map and investigate trends and influences of vegetation greenness in Whitehorse, Yukon from 1984 to 2009. The following research questions were investigated:

1. Does a significant vegetation browning or greening trend exist in Whitehorse, Yukon?

Research has yet to investigate boreal greening or browning trends in southern Yukon at the landscape level. Recently, Ju and Masek (2016) developed a Landsat time-series of Canada and Alaska from 1984 to 2012 . Results show that $29.4 \%$ and $2.9 \%$ of forested areas, unaffected by wildfire, displayed vegetation greening and browning, respectively. Significant trends exist in the Whitehorse area, although much of the results are not validated at the landscape level due to the large spatial extent of the Ju and Masek (2016) study. Hence, a correlation study, with local environmental factors, was used in the present study to understand change at the landscape scale.

\section{Can browning or greening trends be attributed to different vegetation classes, landscape} positions, or topographic classes?

Limited research exists on forest ecology using GIS or remote sensing at the landscape scale in Yukon. Instead, past research has focused on tree ring analysis at the site or stand scale. At the regional scale, climate-biomes or cliomes were developed based on climate data and different land classification systems as loosely bounded areas within which management and research are possible. For example, Rowland et al. (2016) used climate biomes to project a transition to boreal grasslands in southern Yukon. Cliomes differ from ecoregions because they are derived from climate data alone (Smith et al., 2004). Landscape scale studies are needed to investigate 
nuanced changes in vegetation communities (related to physical environmental variables) that occurred in the past and may continue in the future.

3. What are the major drivers impacting brownness and greenness on a landscape scale?

Natural disturbances and climate influences impact vegetation through complex interactions. Drought and insects are important to forest disturbance dynamics (Malmstrom and Raffa, 2000; Hogg et al., 2002; Hall et al., 2016). Meanwhile, climate change is linked to changes in boreal vegetation (Stocker et al., 2013). Greening or browning trends need to be attributed to specific disturbance agents or climate change to adequately create adaptation strategies. 


\section{Chapter 2. Literature Review}

Designing a remote sensing study involves a complex hierarchy of decisions based upon data availability, computational capacity, and analytical techniques as well as an in-depth knowledge of what is being researched. Accordingly, forest-focussed remote sensing research very broadly aims to: (1) test the applicability of different methodologies and data to answer spatial questions about the state of forests; and (2) relate findings by contributing to a broader understanding of forests and ecological processes outside of remote sensing. This review systematically analyzes academic literature, through a step-by-step discussion of research into boreal forest greening or browning at multiple scales, while also providing sufficient context for the use of remote sensing in forestry.

\subsection{Study Area}

The City of Whitehorse is the capital of Yukon Territory and the largest city in northern Canada with an area of $417 \mathrm{~km}^{2}$ (Figure 2.1). Conducting remote sensing research within the municipal boundary of Whitehorse is complemented by the existence of ancillary data, and local expertise, where these benefits are afforded by a comparatively high population density and the centre of municipal government. Unlike much of the boreal north that is managed by Federal and Territorial/Provincial governments, Whitehorse's municipal government provides additional capacity to manage forests on a much more detailed spatial scale. For example, the City of Whitehorse has enacted a Regional Parks Plan in which $30 \%$ of the total municipal area will be conserved based upon environmental, community and recreation values (City of Whitehorse, 2014). The Regional Parks Plan has set a decision-making strategy to ensure the parks stay "healthy, beautiful and accessible for years to come" (City of Whitehorse, 2014). 


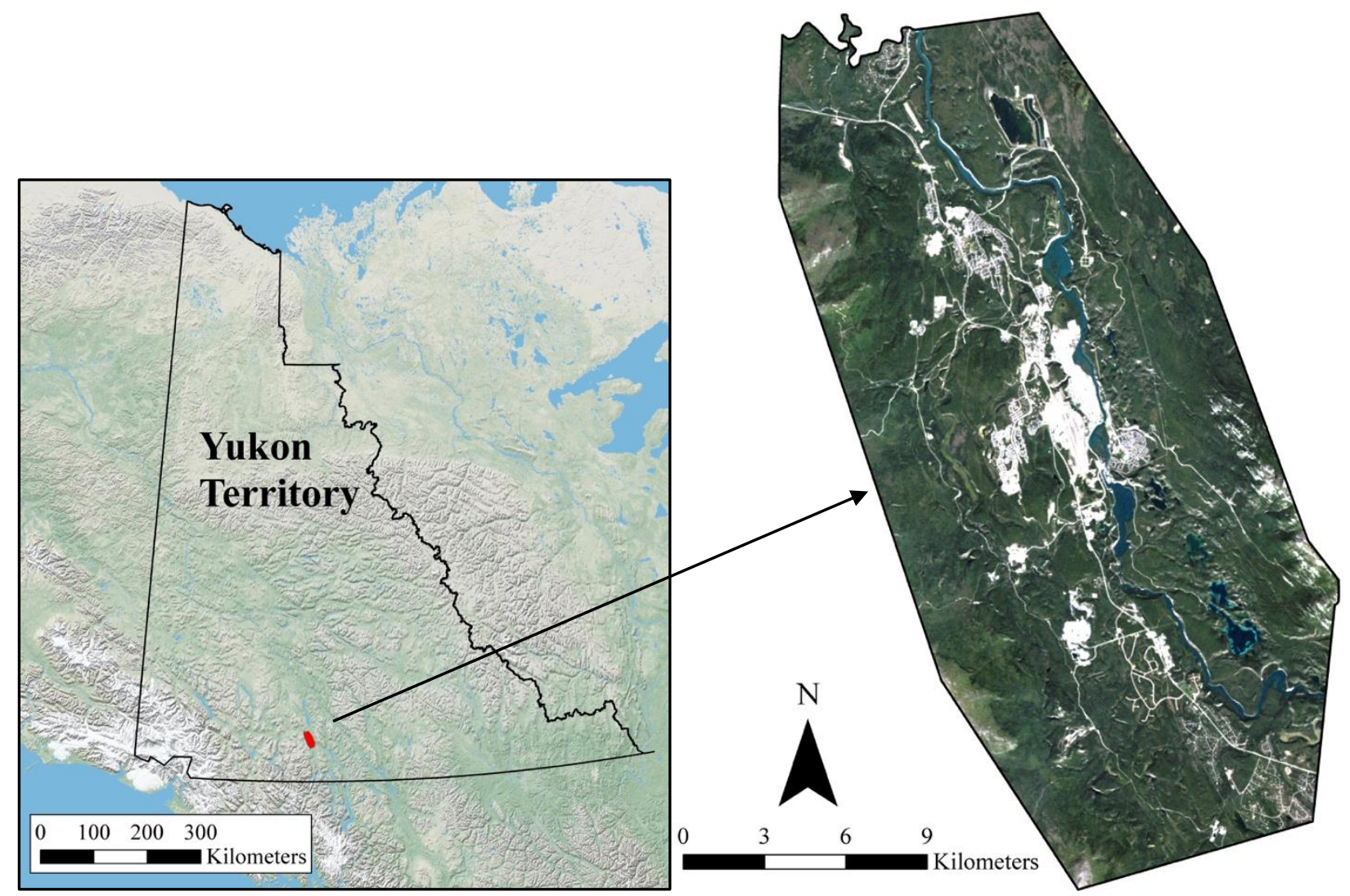

Figure 2.1: Yukon Territory with Whitehorse study area (magnification). Study area image from Landsat ETM scene.

\subsubsection{Geography and Climate}

Whitehorse is a part of the boreal cordillera and is characterized by rolling hills, broad valleys and dissected plateaus with topographic relief averaging from 500 to $1500 \mathrm{~m}$ above sea level (Smith et al., 2004). Coniferous and mixed woodland forests are dominant vegetation cover, resulting from the rain shadow effect and forest fire regime. Depending on site characteristics, dominant tree species include: lodgepole pine (Pinus contorta), white spruce (Picea glauca), trembling aspen (Populus tremuloides), subalpine fir (Abies lasiocarpa) and paper birch (Betula papyrifera) (Oswald and Brown, 1986). Other tree species include balsam poplar (Populus balsamifera) and black spruce (Picea mariana). Whitehorse was extensively glaciated 14,000 years ago (Hughes et al., 1969). Thus, glacial till is widespread throughout the region; surface material is course textured and has incorporated little organic matter since the last 
glaciation, making brunisols the dominant soil type (Davies et al., 1983). Whitehorse is in the sporadic discontinuous permafrost zone, where permafrost underlies less than one quarter of the landscape (Brown, 1976). Permafrost mainly occurs on north facing slopes and fine-textured lacustrine deposits.

The southern lakes region where Whitehorse is found has a cold continental climate with an average yearly temperature of 0 to $-2^{\circ} \mathrm{C}$ and average yearly precipitation of $200-325 \mathrm{~mm}$ (Smith et al., 2004). Since 1960, annual temperature has increased by $0.4^{\circ} \mathrm{C}$ per decade and precipitation has increased by $1.6 \mathrm{~mm}$ per decade (Hennessey and Striecker, 2011). Increases in precipitation has mostly occurred in the summer months while most warming has occurred in winter. Annual average flow of the Yukon river in Whitehorse has not changed despite accelerated melting glaciers in the upper Yukon basin. Climatic trends are provided in Table 2.1.

Table 2.1: Climatic trends for Whitehorse, Yukon using non-parametric trend analysis (Table after Hennessey and Striecker, 2011).

\begin{tabular}{llll}
\hline Climate Variable & $1961-1990$ & $2000-2009$ & Rate of Change \\
\hline Annual temperature & $-1.1 \pm 1.2$ & $0.0 \pm 0.9$ & $0.4^{\circ} \mathrm{C} /$ decade \\
Winter temperature & $-15.9 \pm 4.5$ & $-13.2 \pm 2.5$ & $0.9^{\circ} \mathrm{C} /$ decade \\
Annual precipitation $(\mathrm{mm})$ & $268 \pm 44$ & $276 \pm 46$ & $1.6 \mathrm{~mm} /$ decade \\
Summer precipitation $(\mathrm{mm})$ & $109 \pm 38$ & $121 \pm 33$ & $2.3 \mathrm{~mm} /$ decade \\
Annual average flow $\left(\mathrm{m}^{3} / \mathrm{s}\right)$ & $244 \pm 31$ & $239 \pm 30$ & $0 \mathrm{~m}^{3} / \mathrm{s}$ per decade \\
Frost-free days & $144 \pm 9$ & $149 \pm 8$ & 2 days per decade \\
\hline
\end{tabular}

\subsection{Remote Sensing}

Remote sensing is the acquisition of information about an object or target from a distance, where these data are usually collected by sensors mounted on a satellite or aircraft (NOAA, 2016). Today, satellite remote sensing provides a consistent and robust method to measure and monitor spatial and temporal attributes of forests (Huete, 2012). It has been commonly used for forest management as a method for land classification, forest vigour 
mapping, vegetation mapping, fire fuel mapping, water stress monitoring and insect infestation mapping (Forsythe and Wheate, 2003; Millward and Kraft, 2004; Wang et al., 2010).

\subsubsection{Early Remote Sensing}

Remote sensing has been actively applied to monitor the state of forests since the early $20^{\text {th }}$ century (Murtha, 1969). The earliest recorded application in Canada was described by Craig (1920) who mapped forest discoloration from spruce budworm defoliation during an aerial survey of northern Ontario. Much of the early forest inventory techniques in the 1920s and 1930s relied heavily on black and white photography (Murtha, 1972). In 1933, near-infrared sensitive film was demonstrated to unequivocally identify diseased parts of a leaf, otherwise scarcely visible to the unaided eye (Bawden, 1933). This was consistent with earlier European literature (Willstatter and Stoll, 1913) that suggested this potential. Colwell (1956) determined nearinfrared film was the most practical for insect and disease detection in forests. Over the next several decades, numerous other studies compared the applications and usefulness of falsecolour, colour and near-infrared sensitive films (Murtha, 1969).

Early glimpses of the Earth's surface resulted from meteorological satellites and manned spacecraft missions: Television and Infrared Satellite-1960 and Mercury Space Mission-1961 (Lillesand et al., 2015). In the 1960s, USGS director, William Pecora, witnessed how aerial

remote sensing had vastly expanded knowledge of Earth's resources and anticipated a time when Earth observation satellites would be routinely used to monitor physical and biological conditions on the Earth's surface (Pecora, 1967). Though, not until well into the Landsat satellite program (beginning in 1972 and continuing to the present) was satellite imagery frequently applied in forestry studies. 


\subsubsection{Satellite Resolution}

A basic knowledge of resolution is fundamental to understanding practical and conceptual qualities of remotely-sensed data. In remote sensing, resolution is the ability of a system to capture and display spatial, temporal, spectral and radiometric information (Campbell, 2007). Spatial resolution refers to individual pixel size, where: coarse resolution systems such as Advanced Very High Resolution Radiometer (AVHRR) and Moderate-resolution Imaging Spectroradiometer (MODIS) have a pixel spatial resolution of $250 \mathrm{~m}$ a side, medium resolution systems such as Landsat have a pixel spatial resolution of $30 \mathrm{~m}$ a side, and fine spatial resolution systems such as light detection and ranging (LIDAR) have a pixel spatial resolution of up to 30 $\mathrm{cm}$ a side. Temporal resolution refers to the revisit time of a satellite or sensor to the same location on the Earth's surface (e.g., Landsat 7 has a temporal resolution of 16 days). Spectral resolution is the ability of a sensor to define wavelength intervals within the electromagnetic spectrum. For example, hyperspectral imagery can delineate 200 or more divisions, whereas multispectral imagery (Landsat sensors) separate spectral information into several bands, only. It is important to note, that much of the electromagnetic spectrum is outside of what is considered visible light. Patterns and processes on the Earth's surface that are not visible to the unaided eye can be revealed by interpreting multi- or hyperspectral imagery. Radiometric resolution is the ability to discriminate different levels of brightness or energy referred to as bits (e.g., with 8-bit data, a pixel value can be scaled to 256 grey levels).

\subsubsection{Landsat}

Landsat 1 was the first earth observation civilian satellite launched in 1972. However, aerial film photography continued to be the optimal choice for forest monitoring (Gimbarrevsky, 1984). In the years following the launch of Landsat 1, scientists were successful in using satellite 
imagery to classify broad vegetation types (Nielsen, 1974), forest growth stages (Lee, 1974), insect infestations (Beaubien and Jobin, 1974), and storm damage (Moore, 1974). Given limited computing power at the time, early Landsat studies concerning forests largely relied on qualitative (visual) interpretations of imagery (Beaubien, 1986). Each Landsat mission built on the subsequent one, with mission objectives becoming sequentially more detailed. Since 1972, the Landsat program has launched six more satellites (Table 2.2). Landsat Thematic Mapper (TM) and Enhanced Thematic Mapper Plus (ETM+) have identical band designations and resolution facilitating cross sensor calibration. Imagery from these two satellites will be used in this study. 
Table 2.2: Landsat satellites and characteristics (Table source: http://landsat.usgs.gov).

\begin{tabular}{|c|c|c|c|c|c|c|}
\hline Satellite & Bands & $\begin{array}{l}\text { Spectral } \\
\text { Resolution }(\mu \mathrm{m})\end{array}$ & $\begin{array}{l}\text { Spatial } \\
\text { Resolution (m) }\end{array}$ & $\begin{array}{l}\text { Radiometric } \\
\text { Resolution }\end{array}$ & $\begin{array}{l}\text { Temporal } \\
\text { Resolution }\end{array}$ & $\begin{array}{l}\text { Acquisition } \\
\text { Years }\end{array}$ \\
\hline Landsat 1-3 & & & & 6 bits & 16-18 days & $1972-2001$ \\
\hline Multispectral & Band 1 & $0.5-0.6$ (green) & 60 & & & \\
\hline Scanner & Band 2 & $0.6-0.7$ (red) & 60 & & & \\
\hline (MSS) & $\begin{array}{l}\text { Band } 3 \\
\text { Band } 4\end{array}$ & $\begin{array}{l}0.7-0.8 \text { (NIR) } \\
0.8-1.1 \text { (NIR) }\end{array}$ & $\begin{array}{l}60 \\
60\end{array}$ & & & \\
\hline $\begin{array}{l}\text { Landsat 4-5 } \\
\text { Thematic } \\
\text { Mapper } \\
\text { (TM) }\end{array}$ & $\begin{array}{l}\text { Band 1 } \\
\text { Band } 2 \\
\text { Band } 3 \\
\text { Band } 4 \\
\text { Band 5 } \\
\text { Band 6 } \\
\text { Band } 7\end{array}$ & $\begin{array}{l}0.45-0.52 \text { (blue) } \\
0.52-0.60 \text { (green) } \\
0.63-0.69 \text { (red) } \\
0.76-0.90 \text { (NIR) } \\
1.55-1.75 \text { (SWNIR) } \\
10.40-12.50 \text { (thermal) } \\
2.08-2.35 \text { (SWNIR) }\end{array}$ & $\begin{array}{c}30 \\
30 \\
30 \\
30 \\
30 \\
120 \\
30\end{array}$ & 8 bits & 16 days & 1984-2012 \\
\hline $\begin{array}{l}\text { Landsat } 7 \\
\text { Enhanced Thematic } \\
\text { Mapper Plus } \\
\text { (ETM+) }\end{array}$ & $\begin{array}{l}\text { Band } 1 \\
\text { Band } 2 \\
\text { Band } 3 \\
\text { Band } 4 \\
\text { Band } 5 \\
\text { Band 6 } \\
\text { Band } 7 \\
\text { Band } 8\end{array}$ & $\begin{array}{l}0.45-0.52 \text { (blue) } \\
0.52-0.60 \text { (green) } \\
0.63-0.69 \text { (red) } \\
0.76-0.90 \text { (NIR) } \\
1.55-1.75 \text { (NIR) } \\
10.40-12.50 \text { (thermal) } \\
2.08-2.35 \text { (mid-NIR) } \\
0.52-0.90 \text { (panchromatic) }\end{array}$ & $\begin{array}{l}30 \\
30 \\
30 \\
30 \\
30 \\
60 \\
30 \\
15\end{array}$ & 8 bits & 16 days & 1999-ongoing \\
\hline $\begin{array}{l}\text { Landsat } 8 \\
\text { Operational Land } \\
\text { Imager } \\
\text { (OLI) }\end{array}$ & $\begin{array}{l}\text { Band } 1 \\
\text { Band } 2 \\
\text { Band 3 } \\
\text { Band } 4 \\
\text { Band 5 } \\
\text { Band 6 } \\
\text { Band 7 } \\
\text { Band 8 } \\
\text { Band 9 } \\
\text { Band 10 } \\
\text { Band 11 }\end{array}$ & $\begin{array}{l}0.43-0.45 \text { (aerosol) } \\
0.45-0.51 \text { (blue) } \\
0.53-0.59 \text { (green) } \\
0.64-0.67 \text { (red) } \\
0.85-0.88 \text { (NIR) } \\
0.85-0.88 \text { (SWNIR) } \\
2.11-2.29 \text { (SWNIR) } \\
0.50-0.68 \text { (panchromatic) } \\
1.36-1.38 \text { (cirrus) } \\
10.60-11.19 \text { (longwave) } \\
11.50-12.51 \text { (longwave) }\end{array}$ & $\begin{array}{l}30 \\
30 \\
30 \\
30 \\
30 \\
30 \\
30 \\
15 \\
30 \\
100 \\
100\end{array}$ & 12 bits & 16 days & 2013-ongoing \\
\hline
\end{tabular}

The Landsat series of satellites is optimal for forestry studies for three reasons (Banskota et al., 2014). First, Landsat has a large historical archive spanning over 40 years (Goward et al., 2006). Second, Landsat has a medium spatial resolution (pixels $15-30 \mathrm{~m}$ a side) and temporal repeat frequency of 16 days that permits the incremental detection of changes on the Earth's surface over a relatively short time span (Wulder et al., 2008a). Third, an open data policy in 2008, offering data free-of-charge, and ever-increasing computational power is making satellite 
remotely sensed data increasingly accessible (Wulder et al., 2012). Moreover, Townshend and Justice (1988) describe the Landsat series of satellites as ideal for capturing and characterizing forest details from natural and anthropogenic disturbances.

\subsubsection{Vegetation Indices}

Spectral indices, spectral variables or vegetation indices, hereafter referred to as VIs, are combinations of spectral bands that are added, divided or multiplied to highlight specific attributes (Huete, 2012; Banskota et al., 2014). In the present research, VIs were used to extract information about green foliage, forest structure and moisture status by relating pixel values to a forest characteristic (see Wang et al., 2010). VIs are often used as preprocessed data for regression and other data analysis in bi-temporal change detection or time-series analysis.

Multiple VIs exist and some have been used for over 30 years (Huete et al., 2013).

\subsubsection{Ratio Indices: Normalized Difference Vegetation Index (NDVI)}

Ratio indices use two spectral bands in a ratio to contrast an absorbing feature with a nonabsorbing reference feature (Huete et al., 2013). The first VI was a simple ratio of near-infrared and red bands (Birth and McVey, 1968). However, the simple ratio was strongly affected by soil reflectance in regions of low-biomass. Thus, Rouse et al. (1973) developed a modification of the simple ratio, that reduced sensitivity to soil reflectance, known as the normalized difference vegetation index or NDVI (as shown in equation 1). Tucker (1979) confirmed a significantly reduced sensitivity to soil reflectance in NDVI by comparing red and near-infrared vegetation reflectance across handheld spectrometers and satellite imagery. Today, NDVI continues to be the most commonly used VI (Kasischke et al., 2004). 
The equation for NDVI is:

$$
\text { NDVI }=\frac{\text { near }- \text { infrared }- \text { red }}{\text { near-infrared }+ \text { red }}
$$

NDVI is effective at identifying vegetation vigour, and can be a proxy for live biomass presence, because plant pigments absorb most red light with chlorophyll and reflect most near-infrared light with mesophyll tissue (Lillesand et al., 2014) (Figure 2.2).
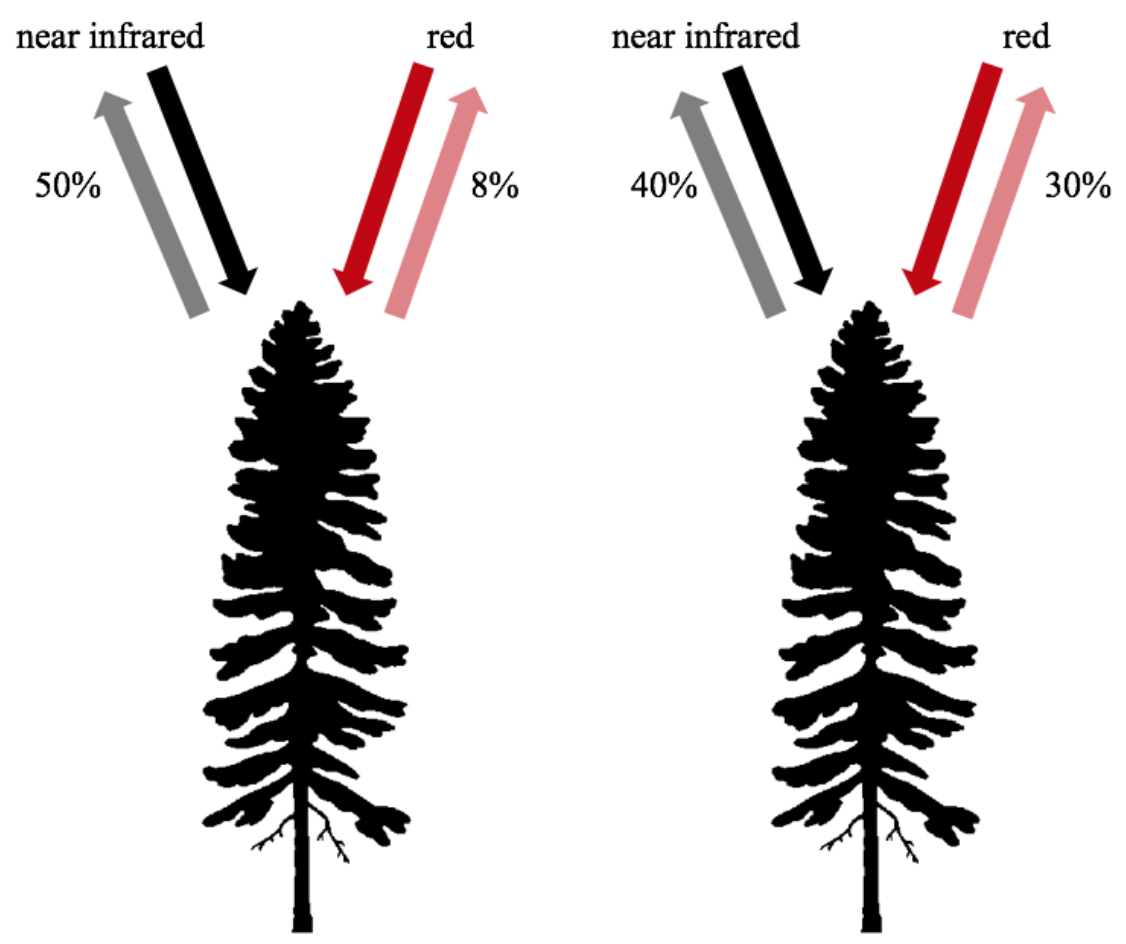

$$
\text { NDVI }=\frac{(0.50-0.08)}{(0.50+0.08)}=0.72
$$$$
\text { NDVI }=\frac{(0.40-0.30)}{(0.40+0.30)}=0.14
$$

Figure 2.2: NDVI calculation for healthy vegetation (left) and stressed vegetation (right). Healthy vegetation absorbs incoming red light while reflecting infrared light. Stressed vegetation reflects more red light and less infrared light. (Diagram after: NASA, 2017)

NDVI values range from +1.0 to -1.0 . Green leaves of deciduous trees, and conifer needles, absorb visible light (especially in the red portion of the electromagnetic spectrum) and, therefore, have high NDVI values. In contrast, bare ground, snow and concrete have lower NDVI values, sometimes close to zero (Neigh et al., 2008). Water has NDVI values that are often negative. NDVI has proven successful in measuring vegetation vigour and density, although it is 
somewhat impacted by atmospheric and soil influences (Schroeder et al., 2011). McManus et al. (2012) measured an increase in NDVI in the boreal-tundra ecotone in northern Quebec indicating increases in peak growing season leaf area. NDVI has also been useful in measuring drought (Wang et al., 2010; Zhang et al., 2013). For example, Nemani and Running (1989) estimated drought and evapotranspiration using a bi-variate regression between land surface temperature and NDVI. Furthermore, effects of drought or foliar moisture have been regularly monitored by the US Forest service to assess fire danger (Burgan et al., 1996). Moreover, NDVI has been used successfully in aboveground biomass estimation in both boreal forests (Dong et al., 2003) and tundra environments (Epstein et al., 2012). Laidler et al. (2008) used field plots, Landsat and IKONOS data to map percent vegetation cover in tundra environments. Jia et al. (2003) quantified changes in biomass resulting from NDVI trends in Alaska. Jia et al. (2003) and Epstein et al. (2012) found a logarithmic relationship between NDVI and biomass. Biomass estimation with remote sensing techniques becomes more challenging with increasing forest stand complexity and varying environmental conditions (Lu, 2006).

\subsubsection{Tasseled Cap Transformation}

Data transformations are less affected by atmospheric effects and sometimes applied because of high variation between satellite-derived spectral indices and on-the-ground measurements (Huete et al., 2012). Tasseled cap transformation (TCT), a data transformation technique, is the reduction of reflectance bands (usually applied to Landsat data) to three orthogonal bands referred to as brightness, greenness and wetness (Kauth, 1976). The TCT is visualized in Figure 2.3. 


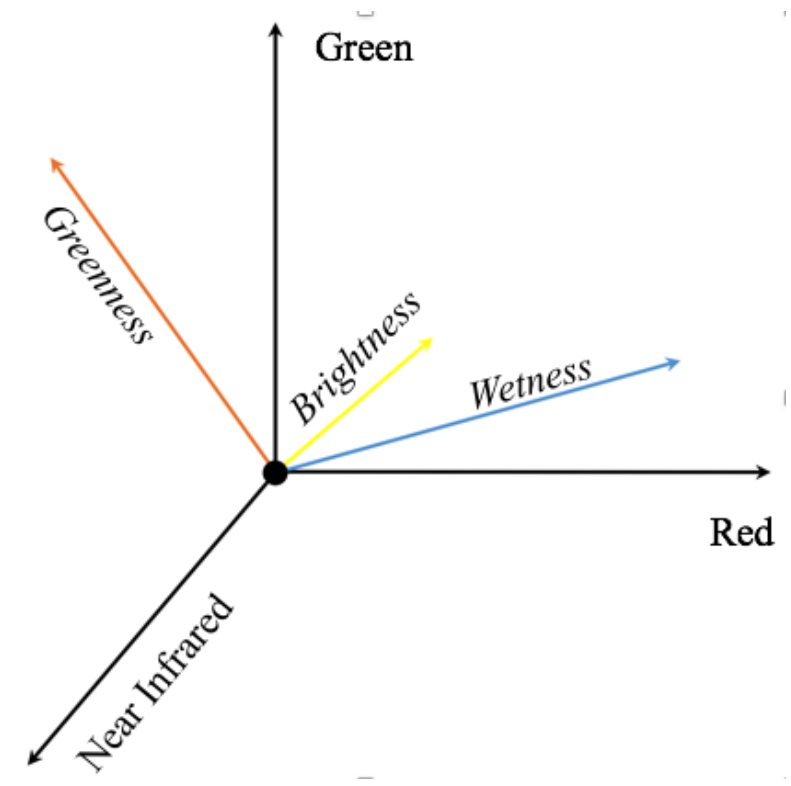

Figure 2.3: Tasseled Cap Transformation (TCT): orthogonal transformation of multiple spectral bands into three tasseled cap bands indicative of greenness, brightness and wetness.

Brightness, the weighted sum of all six reflective bands, is associated with soil characteristics, such as soil texture and moisture (Crist et al., 1986). Furthermore, TCT brightness has demonstrated high sensitivity to forest disturbances including drought and insect infestations (Hais et al., 2009). Greenness displays the contrast between all visible bands and near-infrared bands, placing emphasis on the blue band (Crist and Cicone, 1984). Thus, it correlates well with plant adsorption of visible light and reflectance of near infrared light and has been used to measure canopy cover, leaf area index and fresh biomass (Wang et al., 2010). The third TCT output, wetness, contrasts the sum of visible and near-infrared bands with the sum of longer infrared bands and displays plant and soil moisture characteristics (Crist and Cicone, 1984).

The disturbance index (DI) is a combination of all tasseled cap transformations (Healy et al., 2005). The equation for DI is:

$$
\text { DI = Brightness }-(\text { Greenness }+ \text { Wetness })
$$


DI assumes that disturbed forest has high brightness and low greenness and wetness values compared to undisturbed forests. DI has been shown to correlate well with forest disturbance in boreal Russia (Healey et al., 2005). Moreover, DI is particularly useful in quantifying insect infestations (Hall et al., 2016). Derose et al. (2011) mapped spruce bark beetle mortality in Utah using four Landsat images and DI. Overall accuracy ranged from 59\% to $71 \%$ when compared to tree cores extracted from 131 sites. Additionally, Hais et al. (2009) accurately differentiated bark beetle and clear-cut disturbances using DI in central Europe.

\subsubsection{Using Multiple Vegetation Indices (VI)}

Using multiple VIs allows for enhanced characterization of forest attributes and limits background interference from soil and atmospheric reflectance (Huete et al., 2013). For example, Hart and Veblen (2015) characterized spruce bark beetle attack in Colorado, with an overall accuracy greater than $88 \%$, by using DI and NDVI in image classification. Spruce bark beetle mortality was identified by combining high DI values and low NDVI values as input to image classification. In a meta-analysis of Landsat imagery, Masek et al. (2008) found disturbance rates of 2-3\% per year from 1990-2000 in Canada and the USA. They classified disturbance using Landsat surface reflectance data as well as both NDVI and DI. Specifically, NDVI was used to distinguish forested areas, while DI was used to distinguish insect, wildfire and clear-cut disturbances.

\subsubsection{Landsat Time Series}

Landsat Time Series (LTS) is a method by which a stack of Landsat images is used to gather information about how a single pixel within the stack of images changes overtime (Kennedy et al., 2007). Therefore, trends can be established by isolating specific spectral qualities and using robust statistical methods, such as regression; trends can be related to 
continuous and discontinuous changes in forest attributes in both positive and negative directions (Kennedy et al., 2014). LTS methods provide a more detailed understanding of the complexity of forest disturbance and dynamics than comparing two discrete points in time, i.e., bi-temporal change methods (Cohen et al., 2010; Wulder et al., 2012). Until recently, many studies relied upon the bi-temporal change approach that uses differences between two images to detect change (Coppin et al., 2004). This method successfully identifies changes in state, but is limited in its ability to establish trends.

LTS is much more robust and comprehensive for most forest change applications. However, interpreting trends requires careful deliberation given a large spatial and temporal extent; as well as it can be challenging to isolate, and follow, specific forest attributes (Banskota et al., 2014). Errors found in the analysis of LTS using VIs that use the near-infrared and red bands such as NDVI (Sulla-Menashe et al., 2016) were credited to several factors: subtle variance in the near-infrared band in Landsat TM 5; differences in viewing geometry between eastern and western portions of Landsat scenes; and modest differences in red-band reflectance over dark surfaces between Landsat TM 5 and Landsat ETM+ 7. Sulla-Menashe et al. (2016) emphasize the importance of data collection and investigation of other VIs not derived from infrared and near-infrared bands-such as the use of TCT.

Use of VIs and LTS in forest health studies is ubiquitous (Jones and Vaughn, 2010; Huete et al., 2012) Furthermore, LTS is rapidly becoming the choice method for forest change analysis (Banskota et al., 2014). For example, Hermosilla et al. (2015) analyzed spectral trends using a breakpoint algorithm in LTS at the regional level for Saskatchewan to successfully detect forest changes (92.2\% overall accuracy) attributed to abiotic, biotic and human disturbances. They distinguish stand-replacing disturbance (insect infestation, disease and drought) from non- 
stand replacing disturbances (urbanization, transportation infrastructure, and timber harvesting). Moreover, Pickell et al. (2015) examined the performance of different indices, including NDVI and TCT, on boreal forest recovery trends in LTS. NDVI and TCT greenness were related to early stage forest regeneration characterized by an abundance of deciduous shrubs or leafy vegetation. Moreover, TCT wetness and brightness can provide further details about increases in vegetation structure and complexity (Frazier et al., 2015).

\subsection{Forest Vigour}

The concept that vegetation communities respond to climate has existed since the early $19^{\text {th }}$ century (Clements, 1936). Remote sensing has identified changes in NDVI in boreal and Arctic regions because of a changing climate (Goetz et al., 2005). In the present study, forest vigour will be defined using NDVI as a surrogate of photosynthetic activity and green leafy biomass or greenness. Therefore, forest vigour can be impacted by various disturbances.

Disturbances can be broadly classified into stand replacing and non-stand-replacing disturbances (Hermosilla et al., 2015). Stand replacing disturbances eliminate a forest stand completely (e.g., wildfire, urbanization and tree harvesting). This research focuses on non-stand replacing disturbances. Non-stand replacing disturbances are more gradual changes to forest health, and can be organized into abiotic and biotic disturbances.

\subsubsection{Abiotic Disturbances}

Climate impacts forest directly through precipitation and temperature and indirectly through the effects of disturbances (Price et al., 2013). Abiotic influences include subtle changes to precipitation and temperature regimes, wildfires and extreme weather events (drought, heavy precipitation, ice storms and wind storms) (Myren, 1994). Drought is the most detrimental abiotic disturbance to forest health and poses a significant threat to boreal ecosystem functions, 
particularly in dry climatic regions (Hogg and Bernier, 2005; Allen et al., 2010). Although annual precipitation is generally expected to increase in the Canadian boreal forest, this must be balanced against increased evaporative demand driven by higher temperatures, as well as more frequent heavy precipitation events and droughts (Price et al., 2013). The aggregate effects can result in moisture deficits for plants that occupy dry sites on south-facing slopes or in large rain shadows. For example, trembling aspen die-back due to drought stress has been identified as a major forest health concern and is becoming more common in Yukon (Yukon Energy, Mines and Resources, Forest Management Branch, 2014). Also, drought can weaken tree defenses thus facilitating the onset of insect or disease infestation (Anderegg et al., 2015).

Gradually increasing temperature has detrimental impacts on the boreal forest. For example, regional decline of permafrost and deepening of the soil active layer are likely to increase drainage altering soil water storage and water availability for plants (Bunn et al., 2007). Regional river discharge in the Arctic and Subarctic display varying results; generally decreasing in North America and increasing in Eurasia (Peterson et al., 2006). This has likely caused widespread decreases in plant available moisture (Bunn et al., 2007). Moreover, the response of individual plants to increased temperatures is complex (Kramer and Kozlowski, 1979). In critical high temperatures, plant respiration increases and photosynthesis decreases. Declines in spruce tree growth in Alaska and northwestern Canada may be due to temperature-induced drought, stress caused by increased evapotranspiration demands (Barber et al., 2000; Lloyd and Fastie, 2002).

\subsubsection{Biotic Disturbances}

Forest insect pests can be categorized as bark beetles and defoliators (Anderegg et al., 2015). Bark beetles are strongly influenced by climate in various ways. For example, larval 
growth and development quickens in favourable warmer temperatures and moderation of winter temperatures can increase winter survivorship (Bentz et al., 2010). Bark beetles induce tree mortality by inhibiting the flow of nutrients as larval feeding and growth of fungal associates occurs in tree phloem tubes. Spruce beetles (Dendroctonus rufipennis) are the most damaging pest to mature spruce forests in Yukon and western North America (Berg et al., 2006).

Defoliators damage trees by feeding on leafy tissue and reducing net primary production.

Defoliators are also influenced by climate. Phenological processes (larval emergence) must be synchronized with physiological events of the host tree, such as bud burst, to enable peak defoliator survivorship (Van Asch and Visser, 2007).

\subsubsection{Cumulative Effects}

Disturbance regimes in the boreal forest are complex and interconnected. For example, between 1990 and 2013 southwest Yukon experienced a spruce bark beetle (infestation that produced over 400,000 ha of white spruce mortality (Yukon Energy, Mines and Resources, Forest Management Branch, 2009). Host tree defenses were initially weakened by a multi-year regional drought that allowed spruce bark beetle populations to exceed endemic levels and start attacking healthy trees. Large contiguous areas of weakened or damage trees create favorable habitat for the spruce beetle allowing populations to exponentially increase (Berg et al., 2006). Subsequently, numerous spruce beetles can overcome the defenses of even healthy trees. Additionally, the unprecedented outbreak contributed to a greatly increased fire hazard by increasing fuel load (dead, dry trees) (Garbutt et al., 2006).

\subsubsection{Regional Scale Forest Vigour}

The first investigations into boreal forest vigour occurred at large regional scales. In Landsat remote sensing studies regional scale generally refers to large swaths of land; countries, 
biomes and states or provinces. Increased photosynthetic activity of vegetation in the northern high-latitudes has been associated with warmer temperatures and longer growing seasons (Keeling et al., 1996). This phenomenon—greening—was first investigated with remotely sensed data and the derivation of NDVI by D'Arrigo et al. (1987), who postulated that seasonal increases in $\mathrm{CO}_{2}$ amplitudes were the result of northern latitude greening. Their study utilized NDVI from course spatial resolution AVHRR satellite imagery (pixels: $250 \mathrm{~m}$ a side) to model atmosphere-vegetation $\mathrm{CO}_{2}$ exchange. Building on this study, Myneni et al. (1997) found similar results by using the Global Inventory Modeling and Mapping Studies (GIMMS) NDVI data set from the AVHRR satellite to investigate regional NDVI trends throughout the northern hemisphere. Increasing NDVI trends were prominent in northwestern Canada and Alaska from 1981 to 1991. In a study comparing NDVI trends in Eurasia and North America, Zhou et al. (2001) first mentioned declining NDVI trends — browning — in the boreal forests of Alaska and northwest Canada. Research suggests that this browning was a result of wide-spread temperature-induced drought (Barber et al., 2000).

High-latitude NDVI trends are inconsistent in time or space (Goetz et al., 2005). GIMMS North American NDVI trends per land cover, temperature, and wildfire maps revealed that increased photosynthetic activity from warming and lengthened growing seasons only accounted for $7 \%$ of greening occurring mostly in tundra. Furthermore, some coniferous forested areas unaffected by fire in northwestern Canada and Alaska experienced browning, a decline in photosynthetic activity. Therefore, it can be stated that deciduous herbaceous vegetation in tundra areas and coniferous vegetation in forested areas are not consistent in their responses to environmental change (Reich et al., 2004). This was confirmed by research focused on interior Alaska that showed no significant trends between declining NDVI and temperature or 
precipitation at the regional scale (Verbyla, 2008). However, further analysis included meteorological and MODIS data to conclude that net primary productivity is generally increasing in tundra regions and decreasing in the boreal forests of North America and Eurasia (Bunn and Goetz, 2006). Moreover, that potential benefits from increases in growing season length could be offset by a positive trend in vapour pressure deficit resulting in moisture stress for many plants. Thus, NDVI trends are largely dependant on plant species and site specific environmental conditions.

In contrast, Alcaraz-Segura et al. (2010) argued that browning trends can be attributed to errors in the GIMMS-NDVI dataset. More specifically that the GIMMS-NDVI dataset did not capture post-wildfire forest regeneration. Studies validating browning trends were summarized by Verbyla (2011). Boreal browning was found to be similar across other satellite sensors, including MODIS (Beck and Goetz, 2011) and Landsat (Parent and Vebyla, 2010). Furthermore, declining NDVI trends were consistent with tree-ring studies (D'Arrigo et al., 2004; McGuire et al., 2010; Beck et al., 2011; Berner et al., 2011). Though there is some disagreement due to data related errors and spatial variability in trends, the weight of evidence supports that browning trends exist in some coniferous areas of the boreal forest dependent upon site-specific enivironmental variables.

In a circumpolar tree-ring study, evidence suggests that a negative relationship between warmer temperatures and tree growth occurs more frequently on warmer sites from direct temperature stress (Lloyd and Bunn, 2007). Additional studies comparing tree ring data sets and NDVI show summer temperature to be more influential than the length of growing season on boreal forest vigour (Kaufmann et al., 2004). More recently, a comparable browning trend in the enhanced vegetation index (EVI), which is less affected by atmospheric influences, was found in 
interior Alaska (Potter, 2014). The overall regional scale boreal browning trend can be attributed to increased drought stress and attack from insects and disease (Barber et al., 2000; Malmstrom and Raffa 2000; Verbyla, 2011).

Wylie et al. (2008) developed a method to monitor ecological change that distinguishes between climate influences and natural disturbances. Their study integrated topographic, meteorological and GIMMS-NDVI data to assess ecosystem performance in Yukon River Basin, Alaska. Underperforming (browning areas) were associated with recent fires or insect infestation, while over-preforming (greening areas) were associated with older fire regeneration areas with large deciduous components. A latter study utilized similar methods, replacing GIMMS NDVI with MODIS-NDVI, to establish baseline conditions and subsequently model future ecosystem performance throughout the Yukon River Basin in Canada and Alaska (Wylie et al., 2014). Results suggest that deciduous components have higher ecosystem performance and that by 2070 changes in disturbance regimes will lead to an increased deciduous component throughout the Yukon River Basin.

At the regional scale, investigations into boreal forest vigour most frequently use course spatial resolution satellites such as MODIS and AVHRR (pixel: $250 \mathrm{~m}$ a side) (Bunn et al., 2007). This was most likely because of limited computing power early-on and easily accessible and standardized NDVI datasets (GIMMS). More research into the mechanisms that drive gradual disturbance at multiple scales (e.g., insect infestation, drought, and responses to shifts in climate) is required to improve our understanding of forest vulnerability and resilience (Sharik et al., 2010). Also, disturbance needs to be studied at scales refelective of management areas, so results can be applied to land-use and forest management plans (Ogden and Innes, 2008). 


\subsubsection{Landscape Scale Forest Vigour}

Remotely sensed data, and associated analytical approaches, are very useful in measuring landscape level forest vigour. Numerous studies compare vegetation indices to detect different disturbances and characterize forest decline and recovery (Wang et al., 2010; Hall et al., 2016). Landscape scale refers to "spatially explicit patterns of landscape mosaics and interactions among their elements, primarily at the scale of kilometers" (Wiens et al., 1993, p. 369).

Investigation into boreal greening and browning at smaller landscape scales provides a more detailed understanding of climatic and ecological drivers. To validate NDVI greening observed in satellite imagery, encroachment of deciduous shrubs at forest-tundra ecotones was documented with repeat aerial photography from 1949 to 2000 in northern Alaska (Sturm et al., 2001). Changes in forest productivity in Alaska are consistent with a biome shift (Beck et al., 2011). Drought-induced browning of interior forests and tundra-forest ecotone greening were established by correlating GIMMS-NDVI data with tree-ring data at the landscape level. The Beck et al. (2011) study concluded that ecological responses were not homogenous and future extents of the boreal biome will be defined by the rate of climate change and habitat availability.

Excluding wildfire, the most detrimental disturbances to boreal forests are insect infestations and drought (Price et al., 2013). Over the last 20 years there have been large increases in climate-driven bark beetle activity in British Columbia, Yukon and Alaska (Carrol et

al., 2003; Berg et al., 2006). Although many regional remote sensing studies in the boreal north deduce insect activity to be an important driver of browning, landscape extent studies often overlook insect or bark beetle outbreaks (Malmstrom and Raffa, 2000). Most of the beetle outbreak research has monitored mountain pine beetle outbreaks in $\mathrm{BC}$ or in the northwest United States (Franklin et al., 2003; Senf et al., 2015). Moreover, climate data is rarely 
incorporated into boreal vigour studies. Verbyla (2015) suggests that regional drought was the largest controller of peak summer NDVI between 2000 and 2014. Using precipitation and temperature data from 26 climate stations between the Brooks and Alaska Range in interior Alaska, his research reported a decline in peak NDVI across all sites that experienced regional drought. However, NDVI trends were not correlated to yearly site specific moisture indices formed with temperatures and precipitation data. This was related to a lag in the vegetation response, by one to two years, to precipitation and temperature (Barber et al., 2000; Juday et al., 2014; Walker and Johnstone, 2014).

In a research forest near Fairbanks Alaska, Baird et al. (2012) examine decline in forest vigour according to different landscape positions, topographic classes and vegetation categories. This was study used $30 \mathrm{~m}$ spatial resolution Landsat images from 1986 to 2009. A decline in forest vigour or NDVI was consistent across classes and landscape positions. This was attributed to change in regional climate gradients as opposed to site specific features. Additionally, deciduous stands had consistently higher NDVI values, and the only positive NDVI trends were on recently burned sites. Similarly, Walker and Johnstone (2014) found a negative relationship between temperature and black spruce tree growth across microclimates indicative of regional drought stress. Furthermore, a regional scale investigation of NDVI according to vegetation classes in the boreal forests of Siberia showed highest NDVI decline in spruce dominated forests and highest NDVI increase in deciduous dominated forests (Miles and Esau, 2016).

At finer scales, Esau et al. (2016) analyzed trends in NDVI associated with rapid urbanization on coarse spatial resolution MODIS images (pixels: $250 \mathrm{~m}$ a side) from 28 small cities in West Siberia. They found large reductions in NDVI values in newly developed areas and an overall browning trend in forests surrounding cities within the boreal ecosystem. Furthermore, 
urban areas displayed the most rapid post-disturbance greening. However, it is unclear how these authors discriminated between natural and human disturbances. Natural disturbances were malgamated into human disturbances because natural disturbances were minimal compared with urbanization and intensive oil and gas development. Complex results from multiple studies at the landscape level increasingly demonstrate the heterogeneity of disturbance and climatic influences on forest vigour.

\subsubsection{Stand Scale Forest Vigour}

It is challenging to differentiate disturbance types and climatic influences at the landscape level without knowledge of ecology at the stand and individual tree scale (Price et al., 2013). Research at this scale uses empirical methods. Research site-specific to Yukon predominantly examined tree-ring and species inventory metrics (Hogg and Wein, 2005; Berg et al., 2006; Griesbauer and Green, 2012; Conway and Danby, 2014; Paudel et al., 2015).

\subsubsection{Spruce Species (white spruce, black spruce)}

Research on Yukon spruce stands focused on insect infestations and temperature-growth relationships. Spruce bark beetle is the most damaging forest pest in Yukon (Garbutt et al., 2006). Tree ring analysis revealed that several stands in southwest Yukon displayed rare occurrences of stand-thinning spruce bark beetle infestation over the last 250 years because fire and cold temperatures have strongly regulated spruce beetle populations in the past (Berg et al., 2006). However, large scale spruce bark beetle outbreaks have become more common, mostly attributable to a changing climate (Garbutt et al., 2006).

Barber et al. (2000) found a strong and consistent negative correlation between annual radial growth and increasing temperatures from 1906 to 1998 for white spruce across Alaska. Also, temperature-induced drought stress disproportionately affected the most vigorously 
growing trees, thus revealing that climate warming may limit carbon uptake by trees in northern latitudes. Spruce stands at the wettest sites are least affected by warming temperatures (Lolyd and Fastie, 2002). Work by D'Arrigo et al. (2004) describes a summer temperature threshold for white spruce radial growth decline near Dawson City, Yukon. Temperatures have exceeded optimum physiological conditions since the 1960s resulting in growth decline. Sites in other parts of Yukon similarly demonstrate a negative relationship between warmer temperatures and spruce growth, although drought was found to be the dominant limiting factor (Miyamoto et al., 2010). In the same study, spruce trees at high elevation sites (cooler temperatures) displayed positive-growth relationships with warmer temperatures because they are already at the altitudinal edge of their range and any increase in growing season length is conducive to growth.

More recently, high-elevation white spruce has displayed greater sensitivity to precipitation and a lessening of increased-growth responses to temperature (Griesbauer and Green, 2012). The white spruce climate-growth relationship is complex (possibly opposite) depending on environmental conditions. Youngblut and Luckman (2008) reconstructed June/July temperatures dating back to $1648 \mathrm{AD}$ in southwest Yukon. These authors found that decline in tree growth was not correlated to warming in the $20^{\text {th }}$ century. Furthermore, Griesbauer and Green (2012) determined that drought (reduced rainfall) is the dominant growth-limiting factor in southern Yukon, whereas snowfall and temperature are more influential in southern and northern regions. No negative correlation between temperature and growth in southern Yukon has been established, but the relationship between temperature and drought is complex and interconnected. A similar complexity between climate and spruce growth exists in the mountainous terrain of Alaska (Juday et al., 2015). Temperature-induced drought has been the dominant growth limiter throughout most stand scale studies in southern Yukon. 


\subsubsection{Deciduous Species (trembling aspen, balsam poplar)}

Deciduous trees are becoming more prominent than coniferous species after forest disturbance events in Yukon. Near Whitehorse, previously burned (1958) mixed-wood valleys show a disproportional regeneration of trembling aspen compared to white spruce, resulting in uneven-aged aspen-grassland-forest closely resembling the aspen-parkland along the northern edge of Canadian prairies (Hogg and Wein, 2005). Furthermore, tree ring analyses revealed both trembling aspen and white spruce growth were strongly influenced by the amount of precipitation, and duration of drought. Thus, a warmer and drier climate may be creating a decrease in forest cover. More frequent droughts may contribute to aspen-dieback as seen in aspen-parkland in Alberta and small Yukon stands (Hogg et al., 2002; Yukon Energy, Mines and Resources, Forest Management Branch, 2015). A post-burn study north of Whitehorse revealed an increased prevalence of trembling aspen on warmer sites (lowland and south-facing slopes) previously dominated by white spruce (Johnstone et al., 2010). Similarly, trembling aspen and balsam poplar proliferated on warm sites and were found to occupy more sites after the large spruce bark beetle disturbance in southwest Yukon (Paudel et al., 2015).

There is recent dendrochronological evidence of the advance of aspen ecotones into grasslands in southwestern Yukon (Conway and Danby, 2014). Using repeat-coverage aerial photography and a time-series of satellite imagery, Conway (2012) illustrates increased grassland fragmentation by trembling aspen forest in the Kluane region. Unlike the southern boreal forest experiencing massive aspen die-back (Michaelian et al., 2011), areas in the northern boreal forest may be experiencing an increase in aspen recruitment. Aspen and spruce have been shown to respond inversely to temperature and precipitation; aspen preferring warmer and drier sites, while spruce preferring cooler and wetter sites (Drobyshev et al., 2013). Generally, there is an 
increase in trembling aspen on sites formally occupied by spruce species after disturbances. However, under certain circumstances, changing site specific variables have promoted aspen range expansion into grasslands or drought-related mortality on dry sites (aspen die back). More research is needed to explain the drivers of trembling aspen recruitment and die-back.

\subsection{Summary}

Interactions between climate or forest disturbance and vegetation greening or browning are very complex and spatially heterogeneous across northern landscapes (Price et al., 2013; Ju and Masek, 2016). Climate influences can produce opposing results at the landscape scale in the same tree species due to unique site characteristics at finer scales (Johnstone et al., 2010; Griesbauer and Green, 2012). Furthermore, areas in the boreal forest are experiencing die-back or accelerated recruitment of specific species because of drought and disturbance regimes (Michaelian et al., 2011; Paudel et al., 2015). In summary, literature investigating forest ecology in the boreal forests of Yukon point to shifting tree species and ecotones coupled with altered disturbance regimes. Given the accelerated rate of climate change and its predicted impacts on the boreal forest (Stocker et al., 2013), it is now more important than ever to begin to understand ecological changes necessary for adaptation and management at appropriate scales (Gauthier et al., 2014). The use of time-series remotely sensed data, in the form of NDVI, is a robust method to gain insights into ecological trends in Yukon at the landscape scale. 


\section{Chapter 3: Vegetation Trends in Whitehorse Yukon, 1984 to 2009}

\subsection{Research Highlights}

- A prevailing greening trend exists in Whitehorse, Yukon.

- Overall precipitation and temperature influence yearly mean NDVI values in Whitehorse, Yukon. Annual mean NDVI increased in years of increased precipitation and decreased in years of drought.

- White spruce and subalpine fir forests displayed the most greening suggesting that both species and associated vegetation cover benefited from increased temperature and precipitation in Whitehorse, Yukon. Additionally, more greening pixels were found in subalpine white spruce indicative of an early-stage biome shift.

- Land cover with large trembling aspen components showed no trend and the most browning. This is likely a result of a widespread aspen serpentine leaf miner outbreak coinciding with the time series as well as drought induced stress on dry southerly sites.

\subsection{Abstract}

To assess temporal greenness trends at the landscape scale for the municipality of Whitehorse, Yukon $\left(417 \mathrm{~km}^{2}\right)$, this study derived a Landsat normalized difference vegetation index (NDVI) time-series based on annual data acquired for summer months, 1984 to 2009. Using a greenest annual pixel approach, NDVI trend analysis of the study area revealed that $37 \%$ of studied land area had significant greening (positive trend in vegetation growth trajectory) $(\mathrm{p}<0.05)$ and that only $1 \%$ of the studied land area had a significant browning (negative trend in vegetation growth trajectory). Yearly mean NDVI values declined in drought years and increased in years with greater amounts of precipitation. Greening pixels were most prevalent in white spruce (Picea glauca) and subalpine fir (Abies lasiocarpa) dominant forests, suggesting that 
increased amounts of precipitation and rising temperatures have benefited both species and associated understory shrub communities. Forests where trembling aspen (Populas tremuloides) are dominant displayed the least greening, which may be explained by the proliferation of aspen serpentine leaf miner (Phyllocnistis populiella) across the land area studied, and drought related die-back on south-facing slopes that have become warmer across the 25 -year study period.

\subsection{Introduction}

Over the last century, boreal forests of northwest Canada and Alaska experienced the most pronounced climate warming compared to other forest regions in North America (Trenberth et al., 2007). Climate change has already impacted the boreal forest; it has been linked to changes in vegetation phenology and productivity (Myneni et al., 1997; Beck and Goetz, 2011), as well as to an increase in the frequency and magnitude of wildfires (Flannigan et al., 2006), insect and disease attack (Kurz et al., 2008; Sturrock et al., 2011) and extreme weather eventsdrought, heavy rain, ice storms and heat damage (Allen et al., 2010). These phenomena are expected to increase under future projections of changes in climate (Price et al., 2013; Gauthier et al., 2014). Forest response to climate change has been spatially heterogeneous across the Subarctic and Arctic regions. Alaska and part of Yukon have experienced regional 'browning' or a decrease in productivity (Lloyd and Fastie, 2002; Berner et al., 2011) because of drought related dieback (Barber et al., 2000). Whereas increased temperature and precipitation has resulted in 'greening' or an increase in productivity in other parts of Canada and Alaska's Subarctic and Arctic (Keeling et al., 1996; Sturm et al., 2001; Tape et al., 2006).

Application of satellite remote sensing has been invaluable to the identification and quantification of ecological change, at various temporal and spatial scales (Kerr and Ostrovsky, 2003). Satellite-derived measurements of vegetation vigour or 'greenness' can act as a proxy for 
forest health and productivity (Pettorelli, 2013). Coarse spatial resolution vegetation greenness studies have used Advanced Very High-Resolution Radiometer (AVHRR) satellite data to monitor changes in greenness at the continental and global scales, and have provided quantitative evidence of widespread increases to vegetation productivity, with some more modest decreases, in Arctic and Subarctic regions (D'Arrigo et al., 1987; Goetz et al., 2005; Bunn et al., 2007; Lloyd and Bunn, 2007; Verbyla, 2008). Medium spatial resolution Landsat satellite data has been used to monitor landscape and regional scale greenness trends at tundra sites (Fraser et al., 2014), forest tundra ecotones (Oltof et al., 2008; McManus et al., 2012) and across Canada and Alaska (Ju and Masek, 2016). Ancillary data such as tree rings, climate data, vegetation inventories, topography and soil characteristics have also been used as a complement to remote sensing data to further explore the nuances of forest change (Kaufmann et al., 2008; Coops and Wulder, 2010; Beck et al., 2011; Berner et al., 2011; Baird et al., 2012; Verbyla 2015). Most vegetation studies have occurred at the forest stand level in southwest Yukon focusing on forest regeneration after disturbance (Hogg and Wein, 2005; Paudel et al., 2015), and on tree growth response to temperature and precipitation (Griesbauer and Green, 2012; Miyamoto et al., 2012). This study used Landsat satellite data together with Yukon government forest health reports and vegetation inventories to investigate greenness trends in Whitehorse, Yukon from 1984 to 2009. Correlation of greenness trends with local environmental factors is an important area of future research (Ju and Masek, 2016). The objectives of this study were to: (1) determine if a regional greening or browning trend exists in Whitehorse, Yukon by using a Landsat normalized differenced vegetation index (NDVI) time series; (2) determine if trends can be attributed to different vegetation, topographic, and soil moisture regime classes; and, (3) investigate how climate influences or disturbance regimes are impacting forest dynamics. 


\subsubsection{Study Area}

The City of Whitehorse is the capital of Yukon Territory and the largest city in northern Canada with an area of $417 \mathrm{~km}^{2}$ (Figure 3.1) Whitehorse is a part of the boreal cordillera characterized by rolling hills, broad valleys and dissected plateaus with topographic relief ranging from 500 to $1500 \mathrm{~m}$ above sea level (Smith et al., 2004). Coniferous and mixed woodland forests are dominant vegetation cover, resulting from the rain shadow effect and forest fire regime. Depending on site characteristics dominant tree species include: lodgepole pine (Pinus contorta), white spruce (Picea glauca), trembling aspen (Populus tremuloides), subalpine fir (Abies lasiocarpa) and paper birch (Betula papyrifera) (Oswald and Brown, 1986). Other tree species include balsam poplar (Populus balsamifera) and black spruce (Picea mariana). Tree species exist in homogenous stands or in contiguous groups depending on environmental characteristics. Whitehorse was extensively glaciated 14,000 years ago (Hughes et al., 1969). Thus, glacial till is widespread throughout the region; surface material is course textured and has incorporated little organic matter since the last glaciation resulting in brunisols being the dominant soil type (Davies et al., 1983). Whitehorse is in the sporadic discontinuous permafrost zone, where permafrost underlies less than one quarter of the landscape (Brown, 1976). Permafrost mainly occurs on north facing slopes and fine-textured lacustrine deposits. 


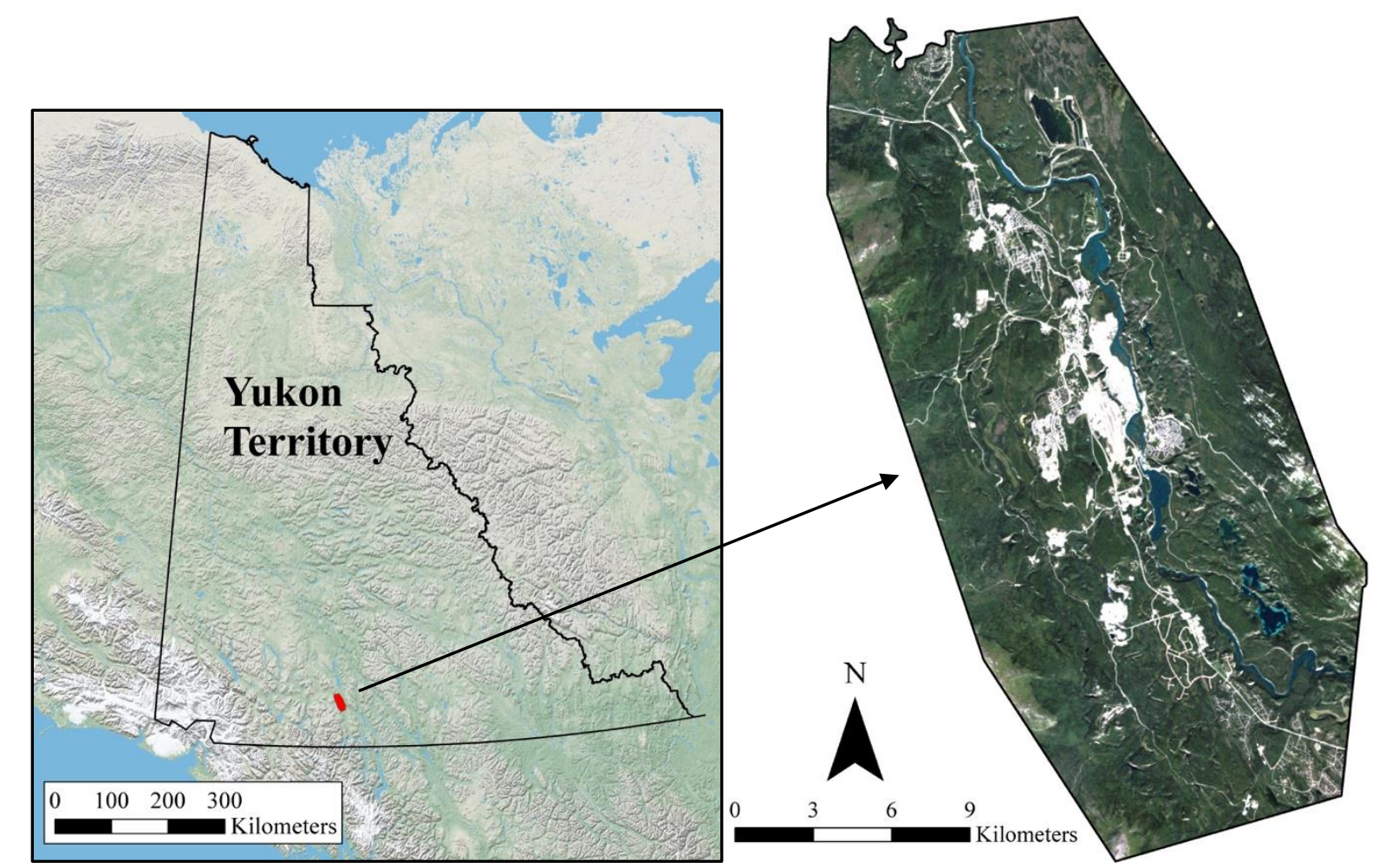

Figure 3.1: Yukon Territory with Whitehorse study area (magnification). Study area image from Landsat ETM scene.

The southern lakes region where Whitehorse is found has a cold continental climate with an average annual temperature of between 0 and $-2^{\circ} \mathrm{C}$, and annual average precipitation of between 200-325 mm (Smith et al., 2004). Since 1960, annual temperature has increased by $0.4^{\circ} \mathrm{C}$ per decade and precipitation has increased by $1.6 \mathrm{~mm}$ per decade (Hennessey and Striecker, 2011). Increases in precipitation have mostly occurred in the summer months while most warming has occurred in winter. Annual average flow of the Yukon river in Whitehorse has not changed despite accelerated melting glaciers in the upper Yukon basin due to increased plant usage and evapotranspiration (Hennessey and Striecker, 2011). Climatic trends are shown in Table 3.1. 
Table 3.1: Climatic trends for Whitehorse, Yukon using non-parametric trend analysis (Table after Hennessey and Striecker, 2011).

\begin{tabular}{llll}
\hline Climate Variable & $1961-1990$ & $2000-2009$ & Rate of Change \\
\hline Annual temperature & $-1.1 \pm 1.2$ & $0.0 \pm 0.9$ & $0.4^{\circ} \mathrm{C} /$ decade \\
Winter temperature & $-15.9 \pm 4.5$ & $-13.2 \pm 2.5$ & $0.9^{\circ} \mathrm{C} /$ decade \\
Annual precipitation $(\mathrm{mm})$ & $268 \pm 44$ & $276 \pm 46$ & $1.6 \mathrm{~mm} /$ decade \\
Summer precipitation $(\mathrm{mm})$ & $109 \pm 38$ & $121 \pm 33$ & $2.3 \mathrm{~mm} /$ decade \\
Annual average flow $\left(\mathrm{m}^{3} / \mathrm{s}\right)$ & $244 \pm 31$ & $239 \pm 30$ & $0 \mathrm{~m}^{3} / \mathrm{s} \mathrm{per} \mathrm{decade}$ \\
Frost-free days & $144 \pm 9$ & $149 \pm 8$ & 2 days per decade \\
\hline
\end{tabular}

\subsection{Methods}

This study builds on conceptual approaches common in NDVI greenness studies using simple linear regression, splines and ancillary data to measure trends in vegetation dynamics. Specifically, it combines approaches of Ju and Masek (2016) who evaluate linear NDVI trends across North America and Baird et al. (2012) who related NDVI trends to landscape units in a research forest near Fairbanks, Alaska. The image compositing using greenest annual pixel approach, was applied to pre-processed Landsat Ecosystem Disturbance Adaptive Processing System (LEDAPS) data. These methods are novel because they allow vegetation greening or browning trends to be spatially and temporally correlated to environmental variables at the landscape and local scale by combining the use of pre-existing geographic data with satellite derived indices. The organizational approach for this study is shown in Figure 3.2. 


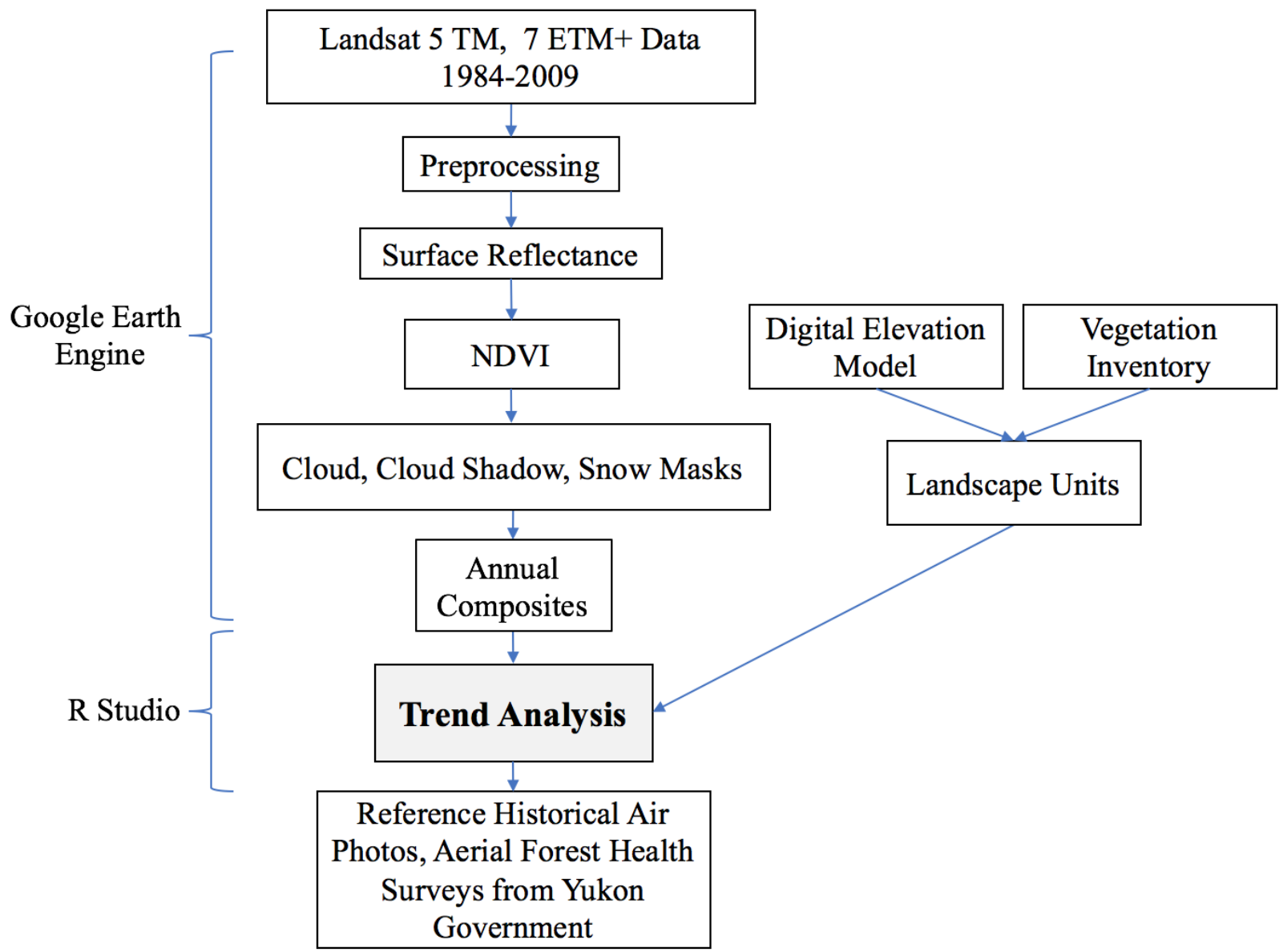

Figure 3.2: Diagram of data collection and processing approach showing the integration of satellite date with local and regional environmental variables.

\subsubsection{Image Selection and Compositing}

Satellite images were acquired from Landsat TM and ETM+ through the USGS Landsat archive via the Google Earth Engine (GEE). GEE is a cloud-based platform allowing free-ofcharge access to petabytes of geospatial data and high-performance computing resources (Gorelick et al. 2016). It includes an internet application programming interface (API) as well as an interactive development environment (IDE). Users have access to geospatial datasets including numerous variations of the Landsat archive (e.g., data processed at different levels, indices such as NDVI). Users also have the option to upload their own data or to download GEE data in common formats to be analyzed in other applications. 
For this research, images must be acquired during leaf-on because spectral signatures of deciduous trees during leaf-off periods are easily confused with disturbed forest (Huang, 2011) and, moreover, because fully leafed-out deciduous canopy is necessary for assessing subtle interannual variability in vegetation greenness. For each World Reference System (WRS) satellite row and path, regional vegetation phenology, including leaf-on period and peak gross primary production, can be derived using MODIS and AVHRR measurements (Schwartz et al., 2002). Images must be free of obstructions caused by shadow and cloud/haze.

Creating image composites is a relatively new remote sensing method of improving image quality (Helmer et al., 2010; Potapov et al., 2012). Composites are created by selecting and merging optimal pixels obtained from several intra-annual images whose acquisition date is close to the desired image selection date. There are different approaches to creating image composites. The best available pixel approach (BAP) represents a paradigm shift in remote sensing as it is not reliant on a single scene-based analysis. Instead, BAP weights individual pixels based on sensor, day of year, distance to cloud/cloud shadow and atmosphere opacity (White et al., 2014). Pixels with the highest weight can then be used for input to the creation of annual leaf-on composites.

In the present study, the greenest annual pixel approach was used (Roy et al., 2010). Greenest annual pixel is a method by which images are composited by selecting individual pixels with the highest NDVI values and having temporal correspondence with a specific phenology range. The phenology time window of June 20 to August 31, that correlates with the deciduous canopy leaf-on period, for Whitehorse, Yukon was used in this study. 


\subsubsection{Preprocessing}

Remote sensing measurements can include substantial errors if not corrected properly (Kerr and Ovstrosky, 2003). Sequential corrections can be categorized into the following geometric, absolute and relative.

\subsubsection{Geometric Correction}

Geometric correction is the component of image processing that includes georeferencing and orthorectifying. Georeferencing refers to image alignment to a geographic location. Orthorectifying is a correction for relief and view direction on individual pixels; it adjusts the spatial and spectral characteristics of each pixel so that it is visualized from nadir. Data from the Landsat archives are orthorectified with minimum $30 \mathrm{~m}$ accuracy depending on ground control points and the best available digital elevation models (Loveland and Dwyer, 2012). Landsat Level-1 products are terrain-corrected and suitable for use as delivered by the USGS (USGS, 2016). Detailed methods are discussed in Toutin (2004).

\subsubsection{Absolute Correction}

Absolute radiometric correction or absolute correction are the preprocessing steps that correct for sensor, solar, atmospheric and topographic effects (Lillesand et al., 2015). Absolute correction attempts to make images comparable across space, time or sensors. Absolute correction can be further categorized from less to more processing in the order of: digital number, at-sensor radiance, top-of atmosphere reflectance and surface reflectance. Each consecutive step increases processing and attempts to decrease unwanted artifacts within images (Figure 3.3). A further step in absolute correction is topographic correction that accounts for illumination effects from slope, aspect and elevation. Band ratios, such as NDVI, are known to supress topographic influences (Holben and Justice, 1981; Colby, 1991; Hale and Rock, 2003). 
There are more complicated methods to suppress topographic influences that require additional data such as DEMs (Vanonckelen et al. 2013). A topographic correction method, if applied, must be carefully selected for the needs of a study. In many cases, such as non-topographically complex regions topographic correction is not required. Furthermore, topographic correction is not common in Landsat time-series applications (Banskota et al. 2014). Moreover, a pixel-based compositing approach has been shown to diminish the need for topographic correction in change detection studies (Chance et al., 2016). To account for topographic effect, the present study investigated topographic landscape units and stratified variables where possible.

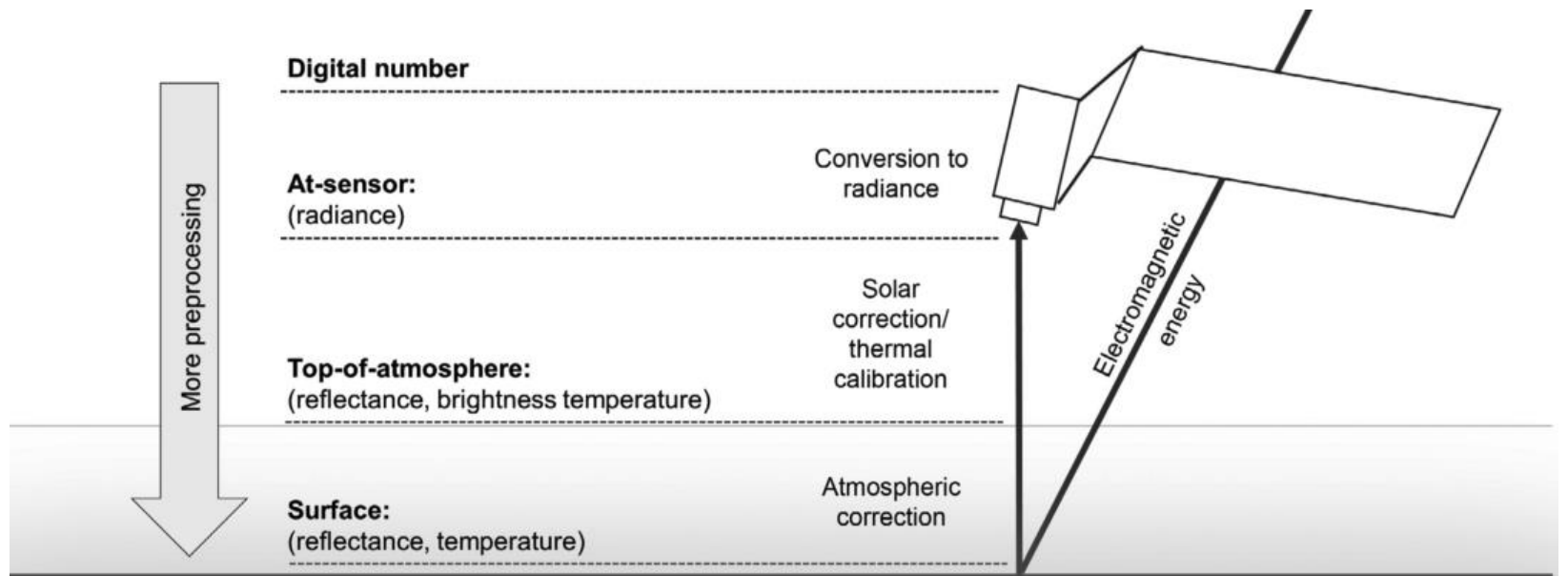

Figure 3.3: Landsat levels of absolute radiometric correction (Figure after Young et al., 2017).

\subsubsection{Relative Correction}

Relative correction is the most aggressive correction technique and can be applied to any one of the levels of preprocessing. It is used to obtain consistent values throughout a time-series by matching all images to a reference image by bringing individual bands to the same radiometric scales. Relative correction can be organized into two overarching methods, histogram matching and pseudo-invariant features. Histogram matching equalizes all pixels from overlapping regions. It is not recommended for Landsat data and is usually used to correct 
images acquired under similar atmospheric and solar conditions (Young et al. 2017). Pseudo invariant features (PIF) are land cover targets of expected 'no-change' in spectral characteristics across overlapping areas in a multi-temporal image stack. A relationship between reference image PIF pixels and image-to-be-corrected PIF pixels is calculated and then applied to all pixels in the image-to-be-corrected (Song et al., 2001). The most common method to establish a relationship between PIFs is simple linear regression. Many manual and automated methods have been proposed for PIF selection (Hall et al., 1991; Schott et al., 1988). PIF correction has been applied to radiance and top-of-atmosphere corrections for LTS (Baird et al., 2012; Li et al., 2014), however, it is seldom applied to surface reflectance data and may introduce additional potential error (Young et al. 2017).

\subsubsection{Surface Reflectance}

Ultimately, the best method must be robust, transparent, consistent throughout all images and requiring minimal user interaction (Bansksota et al., 2014). Historically, preprocessing of LTS images involved different combinations of corrections (Schroeder et al., 2006). Landsat Ecosystem Disturbance Adaptive Processing System (LEDAPS) offers pre-preprocessed images that are atmospherically corrected and converted into surface reflectance data (Masek et al., 2006). Available preprocessed imagery, and the fact that the USGS is openly sharing the LEDAPS code, is stimulating use among researchers (Banskota et al., 2014). LEDAPS estimates and corrects for atmosphere optical thickness using the dark dense vegetation method (Kaufman et al., 1997) and a combination of other ancillary sources including TOMS (Total Ozone Mapping Spectrometer), column water vapor data, digital topography and surface pressure data (Ganguly et al., 2012). 
As with some of the most contemporary vegetation greening and browning research in northern Canada and Alaska (see Ju and Masek, 2016), the present study opted to use preprocessed LEDAPS surface reflectance data because it is arguably the most standardized Landsat data set available ultimately making the study more robust, replicable and comparable to up-to-date research. Yet another advantage of the LEDAPS preprocessed data is that it includes cloud, water and snow masks for each individual image. In the current study, these masks were used to ensure that NDVI trends and disturbances were not artifacts of clouds, snow or water. Additionally, masks for human and wildfire disturbance were created and applied by using Yukon Government land cover data (Yukon Energy, Mines and Resources, Forest Management Branch, 2013). NDVI was chosen as the proxy for greenness and forest vigour because of its extensive history in past forest studies, in particular in boreal and Arctic regions (Verbyla, 2011; Pettorelli, 2013), as well as for its inherent value in suppressing unwanted topographic effects. NDVI images were calculated from Landsat pre-collection surface reflectance data within Google Earth Engine.

\subsubsection{Preparation of Greenest Annual Image Composites}

Using GEE, all Landsat surface reflectance L1T1 pre-collection scenes from 1984 to 2012 were selected on the basis that each image had less than $80 \%$ cloud cover and was acquired between June 20 and August 24 each year. This intra-annual time window corresponds to a time when northwestern boreal forests are phenologically similar in seasonal peak NDVI. Cloud, cloud shadow and snow masks were applied to each image using the USGS provided CF-mask algorithm. To generate yearly cloud-free images the greenest annual pixel method whereby pixels with the highest NDVI value within the seasonal range were selected as inputs for the composite images (Roy et al., 2010). Between two and nine Landsat images were included from 
each year to create the greenest annual composites, where 1991 and 1986 had the least and most independent Landsat scene contributions, respectively. Landsat 7 ETM+ NDVI images were standardized to correspond with Landsat 5 TM NDVI brightness values using a scale factor of 0.964 (Ju and Masek, 2016). Two additional precautions were used to avoid unwanted pixels representing cloud, cloud shadow, bare ground, water and snow-covered areas. First, all pixels with an NDVI value less than 0.3 were excluded from analysis. Typically, the NDVI range for vegetation is 0.4 to 0.8 . Second, polygons generated from the Yukon Government vegetation inventory were used to remove non-vegetated or disturbed areas from the analysis.

\subsubsection{Time Series Analysis}

Preprocessed images were opened in R Studio (ver. 3.4.1) ( R Core Team, 2015) where the Raster Package was used to analyze spatial and temporal trends in NDVI (Hijmans et al., 2016). Trajectory-based change detection was used to investigate vegetation change. Trajectorybase change detection analyzes temporal patterns in a single pixel throughout an image stack. This method's advantage is that trends and gradual changes (nuances) can be identified and documented, as opposed to bimodal image differencing and image post-classification that use a binary change or no change-approach (Coppin et al., 2004; Banskota et al., 2014). Moreover, in bi-temporal change detection, spectral variances caused by geometric misregistration, variability in illumination (shadows and reflectance), and issues surrounding phenology and the image selection date require manual user designation (Lu et al., 2004). Bi-temporal change detection, and interpretation of change, over large areas is arduous, time consuming, and can be prone to error.

Sulla-Menashe et al. (2016) warn of subtle spectral variability in TM and ETM+ sensors, especially in the red and near-infrared bands, that may lead to spurious NDVI time-series results. 
However, numerous studies have used both sensors conjunctively without issue (Parent and Verbyla 2010; Baird et al., 2012). Ju and Masek (2016) provide a method for cross-sensor calibration by examining overlapping regions and establishing a relationship via ordinary least squares regression. The result is a multiplication factor of 1.03723 that can be applied to Landsat 5 TM images to standardize NDVI reflectance values to those of Landsat 7 ETM+ images. This method was implemented on the time-series image stack used in the present research.

Manual trajectory-based change detection, and curve fitting (linear and spline regression), was applied to the time-series image stack across the 25-year period, 1984 to 2009 . Although less sophisticated than automated change detection algorithms such as Vegetation Change Tracker (Huang et al., 2010) and Landtrendr (Kennedy et al., 2010), manual approaches require a more intimate knowledge of the study area and are more flexible allowing researchers to specify the analytical procedure independently for individual study sites. Linear regression is a common method to investigate NDVI trends (Baird et al., 2012; Ju and Masek, 2016; Vogelmann et al., 2016). In the present study, Linear regression was performed on the timeseries image stack stratified by different landscape units. To examine the effect of annual climate variability, a cubic spline regression was applied to yearly mean NDVI values for the study area. The spline fitting approach is advantageous because it is not constrained by a prescribed shape rather it can be fitted more precisely to the data (Bradley et al., 2007). Curve fitting has been used with time-series analyses to document and measure both fire and insect disturbance (Goetz et al., 2006; Goodwin et al., 2010).

\subsubsection{Landscape Units and Ancillary Data}

The use of ancillary data to complement analyses with multispectral imagery is a welltested method and has been implemented since the 1970s (Hoffer et al., 1975; Hutchison, 1982; 
Kasischke et al., 2004). More recently, it has proven invaluable in interpreting time-series remotely sensed data and assessing gradual change (Voglemann et al., 2012; 2015). In the current study, trends in NDVI were attributed to specific landscape units that will be developed from vegetation inventory data and digital elevation models (Yukon Government, 2016). Landscape units consist of vegetation classes, landscape positions and topographic classes. Vegetation and management strata classes were determined by the Yukon Government's vegetation inventory data (Yukon Energy, Mines and Resources, Forest Management Branch, 2013). Aspect units and landscape positions were derived from a digital elevation model.

Moreover, white spruce (the most abundant forest tree in the Whitehorse study area) was stratified by landscape position. Locations of statistically significant vegetation change arising from the time-series analysis were compared to historical aerial photographs, and forest health surveys (Yukon Energy, Mines and Resources, Forest Management Branch, 2009), to facilitate explanation of change revealed in the time-series approach.

Whitehorse study area, landscape and burn area classes were provided by the Yukon Government vegetation survey (Table 3.2). Aspect classes were constructed using a 5 m DEM.

Table 3.2: Landscape unit area classes with associated descriptions.

\begin{tabular}{|l|l|}
\hline Name & Description \\
\hline $\begin{array}{r}\text { Whitehorse Study } \\
\text { Landscape } \\
\text { Lowlands } \\
\text { Uplands } \\
\text { Subalpine }\end{array}$ & $\begin{array}{l}\text { Pelow 665 m at Yukon River valley bottom. } \\
\text { Mid-elevations not affected by surface water or water. } \\
\text { Forests adjacent to alpine areas characterized by sparse tree cover and the presence } \\
\text { of subalpine fir. }\end{array}$ \\
\hline $\begin{array}{r}\text { Aspect } \\
\text { North-facing }\end{array}$ & $\begin{array}{l}315^{\circ} \text { to } 45^{\circ} \\
135^{\circ} \text { to } 225^{\circ} \\
\text { No aspect }\end{array}$ \\
Less than 5\% gradient. \\
\hline $\begin{array}{r}\text { Burn Areas } \\
1958 \text { and }\end{array}$ & Burn areas from Yukon Government vegetation inventory. \\
\hline
\end{tabular}


Leading species classes were extracted from the Yukon Government vegetation inventory. Leading species were characterized by species that occupied over $60 \%$ of overall tree abundance. Leading species classed consisted of birch, balsam poplar, trembling aspen, lodge pole pine and white spruce. All deciduous trees were grouped into a single species class to evaluate the overall trend occurring in broadleaved trees. Conifers were not grouped together because together they comprised of over $90 \%$ of the study area. Conifer response dictates the overall trend of the study area. Leading species polygons may not always represent homogenous and contiguous forest stands. This challenge was addressed by using management strata classes that identify groupings of tree species to further disseminate forest stand structure.

\section{Management strata were derived from the Yukon Government vegetation inventory}

(Table 3.3).

Table 3.3: Yukon Government management strata.

\begin{tabular}{|c|c|}
\hline Strata Name & Description \\
\hline Spruce & $\begin{array}{l}\text { Spruce and fir stands where the combined spruce and fir component exceeds } 80 \% \\
\text { based on crown closure. }\end{array}$ \\
\hline Lodgepole Pine & Lodgepole pine stands where the pine component exceeds $80 \%$. \\
\hline Deciduous & Aspen, balsam poplar and white birch stands where these exceed $80 \%$. \\
\hline Spruce/Pine & Spruce leading stands where the secondary species is lodgepole pine. \\
\hline Spruce/Deciduous & $\begin{array}{l}\text { Spruce leading stands where the secondary species is aspen, balsam poplar or } \\
\text { birch. }\end{array}$ \\
\hline Spruce/Deciduous & Lodgepole pine leading stands where the secondary species is spruce or fir. \\
\hline Pine/Deciduous & $\begin{array}{l}\text { Lodgepole pine leading stands where the secondary species is aspen, balsam } \\
\text { poplar or white birch. }\end{array}$ \\
\hline Pine/Spruce & Lodgepole pine leading stands where the secondary species is spruce or fir. \\
\hline Pine/Deciduous & $\begin{array}{l}\text { Lodgepole pine leading stands where the secondary species is aspen, balsam } \\
\text { poplar or white birch. }\end{array}$ \\
\hline Deciduous/Spruce & $\begin{array}{l}\text { Aspen, balsam poplar or birch leading stands where the secondary species is } \\
\text { spruce or fir. }\end{array}$ \\
\hline Deciduous/Pine & $\begin{array}{l}\text { Aspen, balsam poplar or birch leading stands where the secondary species is } \\
\text { lodgepole pine. }\end{array}$ \\
\hline Fix & Fir stands where the fir component exceeds $80 \%$. \\
\hline Fir Mix & Fir stands where the secondary species in spruce or pine. \\
\hline
\end{tabular}


Soil moisture regime classes were derived from the Yukon Government vegetation

inventory (Table 3.4).

Table 3.4: Soil moisture classes.

\begin{tabular}{|c|c|c|}
\hline Class & Description & Effective Soil Texture \\
\hline Dry & $\begin{array}{l}\text { Majority of soil is coarse fragments. Water removed extremely rapidly } \\
\text { in relation to supply. Soil is moist for a negligible period following } \\
\text { precipitation. }\end{array}$ & $\begin{array}{l}\text { Gravel, cobbles, stones, } \\
\text { boulders }\end{array}$ \\
\hline $\begin{array}{l}\text { Moderately } \\
\text { Dry }\end{array}$ & $\begin{array}{l}\text { Water removed very rapidly in relation to supply. Soil is moist for brief } \\
\text { periods following precipitation. }\end{array}$ & $\begin{array}{l}\text { Very coarse sands, coarse } \\
\text { sand, loamy coarse sand, } \\
\text { and silty coarse sand }\end{array}$ \\
\hline $\begin{array}{l}\text { Moderately } \\
\text { Fresh }\end{array}$ & $\begin{array}{l}\text { Water removed rapidly in relation to supply. Soil is moist for short } \\
\text { periods following precipitation. }\end{array}$ & $\begin{array}{l}\text { Medium sand, loamy sand } \\
\text { to sandy loam }\end{array}$ \\
\hline Fresh & $\begin{array}{l}\text { Water removed readily in relation to supply. Water available for } \\
\text { moderately short periods following precipitation. }\end{array}$ & $\begin{array}{l}\text { Sandy loam to very fine } \\
\text { sands }\end{array}$ \\
\hline Very Fresh & $\begin{array}{l}\text { Water removed somewhat slowly in relation to supply. Soil may } \\
\text { remain moist for significant but sometimes short periods of the year. }\end{array}$ & $\begin{array}{l}\text { Silty loams to sandy } \\
\text { clayey loams and clays }\end{array}$ \\
\hline $\begin{array}{l}\text { Moderately } \\
\text { Moist }\end{array}$ & $\begin{array}{l}\text { Water removed slowly enough to keep the soil wet for a significant } \\
\text { part of the growing season. Some temporary seepage. Must have } \\
\text { mottling above } 50 \mathrm{~cm} \text {. }\end{array}$ & $\begin{array}{l}\text { Variable depending on } \\
\text { seepage }\end{array}$ \\
\hline Moist & $\begin{array}{l}\text { Water removed slowly enough to keep the soil wet for substantial parts } \\
\text { of the growing season; seepage common. }\end{array}$ & $\begin{array}{l}\text { Must have mottling } \\
\text { variable depending on } \\
\text { seepage }\end{array}$ \\
\hline Very Moist & $\begin{array}{l}\text { Water removed slowly enough to keep the soil wet for most of the } \\
\text { growing season. Permanent seepage and mottling present possibly } \\
\text { weak gleying. }\end{array}$ & $\begin{array}{l}\text { Variable depending on } \\
\text { seepage }\end{array}$ \\
\hline $\begin{array}{l}\text { Moderately } \\
\text { Wet }\end{array}$ & $\begin{array}{l}\text { Water removed slowly enough to keep the soil wet for most of the } \\
\text { growing season. Permanent seepage and mottling present gleying in } \\
\text { mineral soils. }\end{array}$ & $\begin{array}{l}\text { Variable depending on } \\
\text { seepage }\end{array}$ \\
\hline Wet & $\begin{array}{l}\text { Water removed slowly enough to keep the water table at or near the } \\
\text { surface for most of the year, gleying mineral and permanent seepage } \\
\text { near the surface. Permanent seepage less than } 30 \mathrm{~cm} \text { below the surface. }\end{array}$ & $\begin{array}{l}\text { Organic and gleyed } \\
\text { mineral soils }\end{array}$ \\
\hline Very Wet & $\begin{array}{l}\text { Water removed so slowly that the water table is at or above the soil } \\
\text { surface all year. Saturated to surface all year. }\end{array}$ & $\begin{array}{l}\text { Organic and gleyed } \\
\text { mineral soils }\end{array}$ \\
\hline
\end{tabular}

\subsubsection{NDVI Trend Extraction by Landscape Units}

NDVI image composites were uploaded into R (ver. 3.4.1) (R Core Team, 2015) where a raster time series image stack was created. Pixels were stratified by landscape units (polygons) obtained from the Yukon Government (Yukon Energy, Mines and Resources, Forest

Management Branch., 2013). Mean NDVI values were extracted from each landscape unit and 
used as inputs into simple linear regression models with year as the dependent variable and mean NDVI as the independent variable. Fire impacted forest as well as anthropogenic disturbances including urban areas, timber harvesting areas, power line corridors, roads, mine tailings, seismic testing and generic clearings were excluded from descriptive statistical summary and omitted from subsequent regression analyses. Distributions of NDVI yearly mean values by each polygon were inspected using: graphical plots, descriptive statistics, kurtosis, skewness, z-scores and the Shapiro-Wilk test.

\subsection{Results}

\subsubsection{Greenest Annual Pixel Composites}

Greenest annual composites scenes used in this study are shown in Table 3.5; annual mean NDVI values, as well as the percentage of unusable pixels were calculated by extracting study area polygons. Greenest annual image composites were determined to be suitable for timeseries analysis; the distribution of pixel values fall within the first and third quantiles of each other (Figure 3.4). These descriptive statistics describing image composites are consistent with literature and recommendations from the USGS (Masek et al., 2006; Banskota et al., 2014; Young et al., 2017), who indicate that surface reflectance data do not require further relative normalization. Additionally, compositing ensures that the greenest available pixel within the phenology window is used for analysis (Roy et al., 2010). 
Table 3.5: Greenest annual composite scenes with satellite sensor used, proportion of study area available for analysis, and associated mean NDVI values.

\begin{tabular}{|c|c|c|c|}
\hline Year & $\begin{array}{l}\text { Satellite and } \\
\text { Sensor }\end{array}$ & $\begin{array}{l}\text { Percentage of } \\
\text { Unusable Pixels }\end{array}$ & $\begin{array}{l}\text { Study Area Mean } \\
\text { NDVI }\end{array}$ \\
\hline 1984 & Landsat 5-TM & 0.3 & 0.662 \\
\hline 1985 & Landsat 5-TM & 3.0 & 0.654 \\
\hline 1986 & Landsat 5-TM & 0.2 & 0.649 \\
\hline 1987 & Landsat 5-TM & 0.3 & 0.682 \\
\hline 1990 & Landsat 5-TM & 0.2 & 0.644 \\
\hline 1991 & Landsat 5-TM & 0.7 & 0.648 \\
\hline 1994 & Landsat 5-TM & 0.2 & 0.689 \\
\hline 1995 & Landsat 5-TM & 0.1 & 0.697 \\
\hline 1996 & Landsat 7-ETM & 3.7 & 0.675 \\
\hline 1997 & Landsat 7-ETM & 0.2 & 0.688 \\
\hline 1998 & Landsat 5-TM & 0.3 & 0.656 \\
\hline 1999 & Landsat 5-TM & 0.3 & 0.686 \\
\hline 2000 & Landsat 5-TM & 0.3 & 0.687 \\
\hline 2001 & Landsat 5-TM & 0.2 & 0.722 \\
\hline 2003 & Landsat 5-TM & 1.0 & 0.674 \\
\hline 2005 & Landsat 5-TM & 0.2 & 0.676 \\
\hline 2007 & Landsat 5-TM & 0.2 & 0.699 \\
\hline 2009 & Landsat 5-TM & 0.4 & 0.688 \\
\hline
\end{tabular}

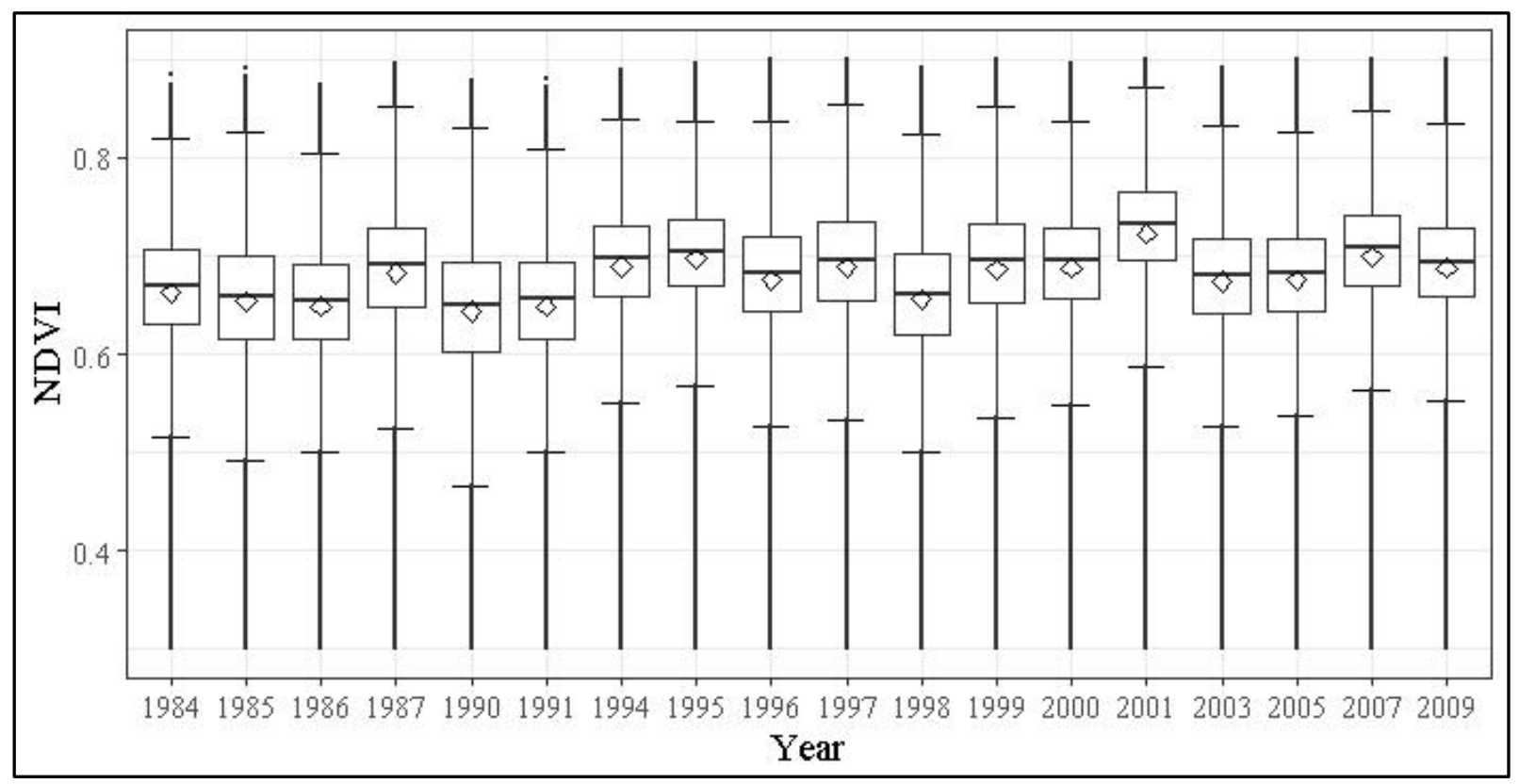

Figure 3.4: Box and whisker plots showing descriptive statistics for each annual NDVI composite included in the time-series image stack for Whitehorse, Yukon. 


\subsubsection{Spatiotemporal Linear Trends in Vegetation Greenness for Whitehorse Study Area}

Pixel-wise time-series trend analysis was used to investigate the presence of a linear trend in changes to vegetation greenness from 1984 to 2009; associated significance maps were created (Figures 3.5 and 3.6). Visual inspection of these pixel trends shows that prominent browning trends are spatially associated with urban and industrial development. The upper-left corner of each figure's map displays the highest concentration of browning pixels not associated with development. Significant greening pixels (increases in vegetation vigour as captured by NDVI) are much more prevalent across the study area, most of which occur in forests that do not

have a history of disturbance. Overall, the average greening trend was determined to be between 0.002 and 0.003 NDVI units per year. 


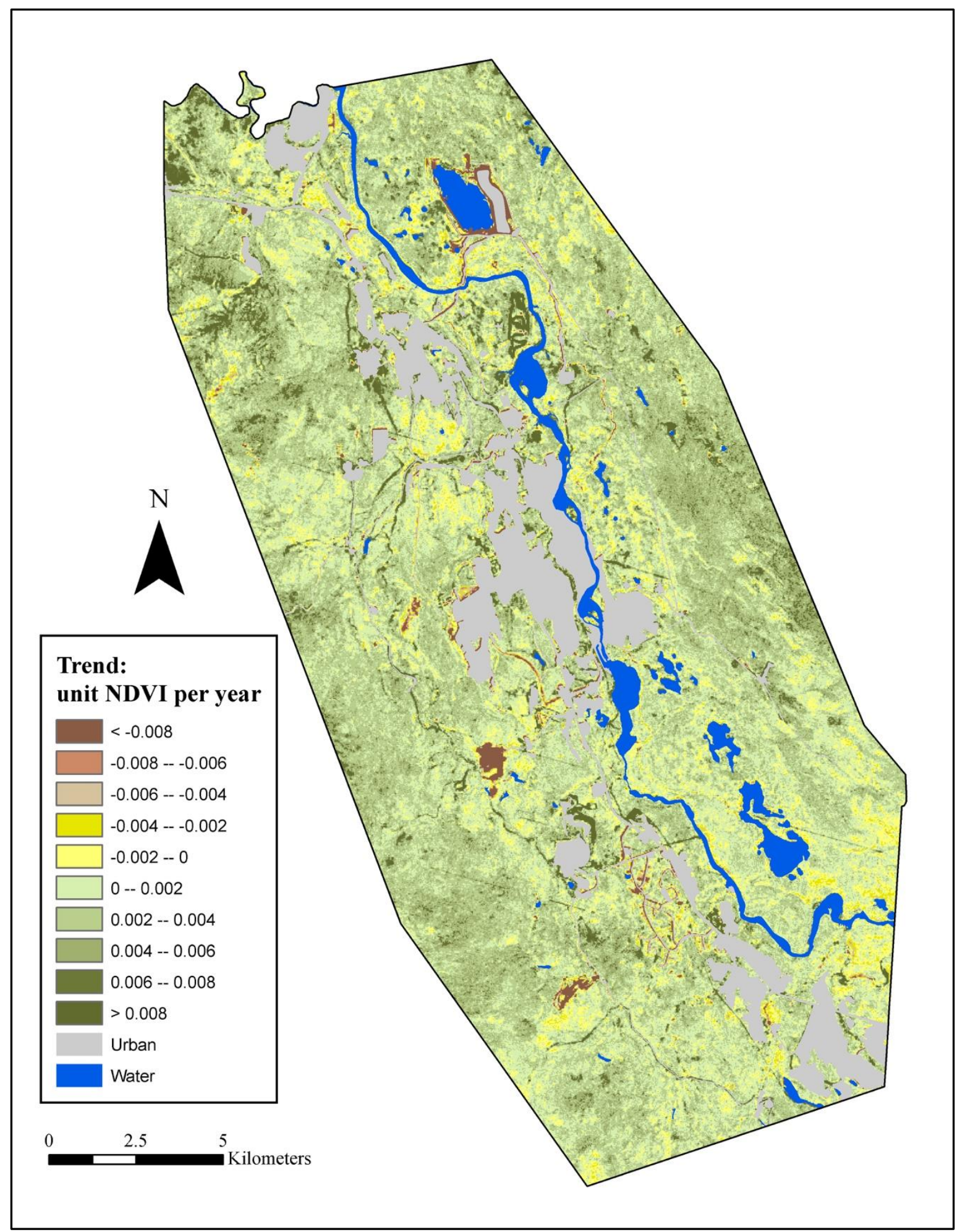

Figure 3.5: Greening trends, as revealed using NDVI composite images, for Whitehorse, Yukon between 1984 and 2009. 


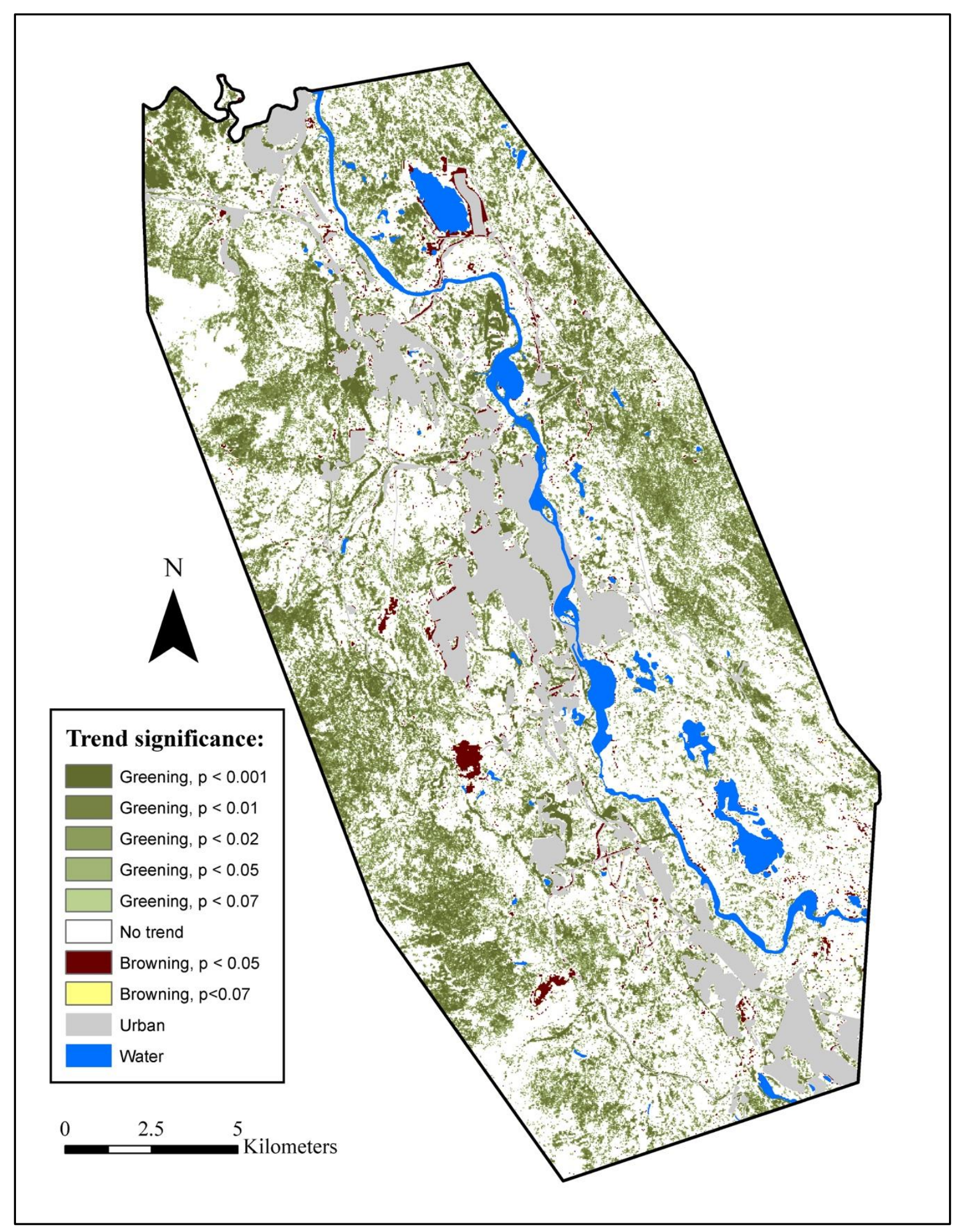

Figure 3.6: Significance of greening trends, for Whitehorse, Yukon between 1984 and 2009. 


\subsubsection{NDVI Trends by Landscape Units}

\subsubsection{Pixel-wise NDVI Trends for Area Classes}

Significant greening pixels were prevalent across area classes (Figure 3.7). $37 \%$ of the study area experienced greening. Conversely, $1 \%$ of the study area experienced browning. The most greening by landscape units occurred in subalpine, north-facing slope and 1958 burn classes. Substantial greening (28\%) and browning (1\%) also occurred in uplands areas, which comprised of a large portion of the study area. The most notable browning occurred in lowlands, south-facing slopes.

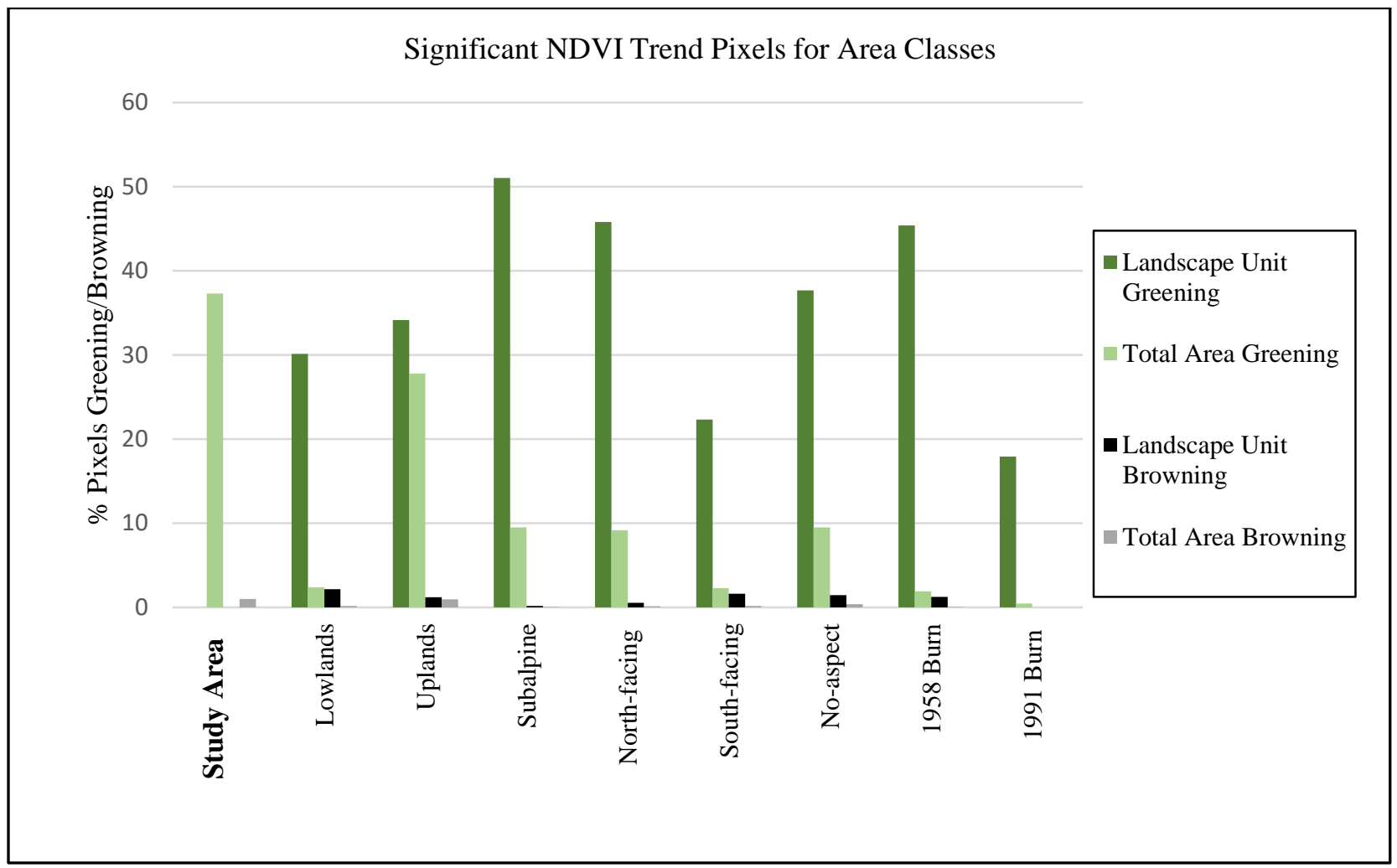

Figure 3.7: Proportion of pixels, within each area class, having significant NDVI trends. Proportions were calculated for percentage of greening or browning pixels located in individual landscape units and percentage of greening or browning pixels located in individual landscape units out of the entire study area or total area. 


\subsubsection{Linear Regression for Area Classes}

Significant positive NDVI trends were widespread among area classes (Table 3.6). The entire Whitehorse study area showed a significant overall greening trend (Figure 3.8).

Table 3.6: 1984 to 2009 linear regression results, by area class, for relationship between NDVI and year of image composite.

\begin{tabular}{llllrll}
\hline Area & Hectares & Pixel Count & Mean & $\mathrm{r}^{2}$ & Slope & $p$ value \\
\hline Whitehorse Study Area & 28833 & 320251 & 0.68 & 0.34 & 0.002 & $0.012^{*}$ \\
Lowlands & 2319 & 25817 & 0.65 & 0.21 & 0.001 & $0.053^{*}$ \\
Uplands & 21295 & 235193 & 0.67 & 0.29 & 0.002 & $0.002^{*}$ \\
Subalpine & 5270 & 58598 & 0.70 & 0.46 & 0.002 & $0.002^{* *}$ \\
North-facing Slopes & 5783 & 64321 & 0.69 & 0.42 & 0.002 & $0.004^{* *}$ \\
South-facing Slopes & 2947 & 32810 & 0.67 & 0.19 & 0.001 & 0.074 \\
No-aspect & 7285 & 81055 & 0.66 & 0.30 & 0.002 & $0.019^{*}$ \\
1958 Burn & 1215 & 13479 & 0.67 & 0.44 & 0.002 & $0.003^{* *}$ \\
1991 Burn (84-09) & 729 & 8105 & 0.66 & 0.05 & 0.001 & 0.370 \\
1991 Burn (91-09) & 729 & 8105 & 0.65 & 0.76 & 0.008 & $0.000^{* * *}$ \\
\hline
\end{tabular}

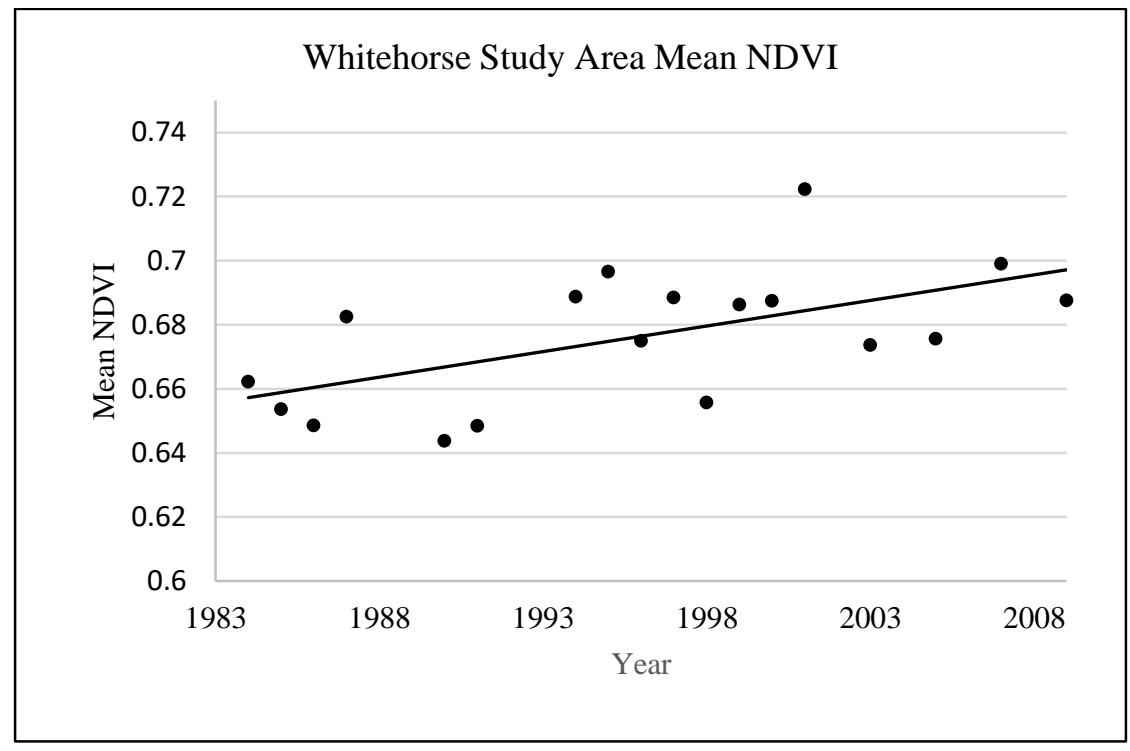

Figure 3.8: 1984-2009 NDVI trend across the Whitehorse study area.

\section{Landscape Positions}

Both uplands and subalpine landscape positions exhibited significant greening trends.

The lowland landscape position had a weak significant greening trend. Mean NDVI values from lowest to highest were lowlands to uplands to subalpine (Figure 3.9). The subalpine and upland 
positions had higher NDVI values most likely due to the increased presence of broad-leaved vegetation. The subalpine landscape position is characterized by a thin canopy and thick understory shrubs. More deciduous stands are present in upland positions relative to lowland positions.

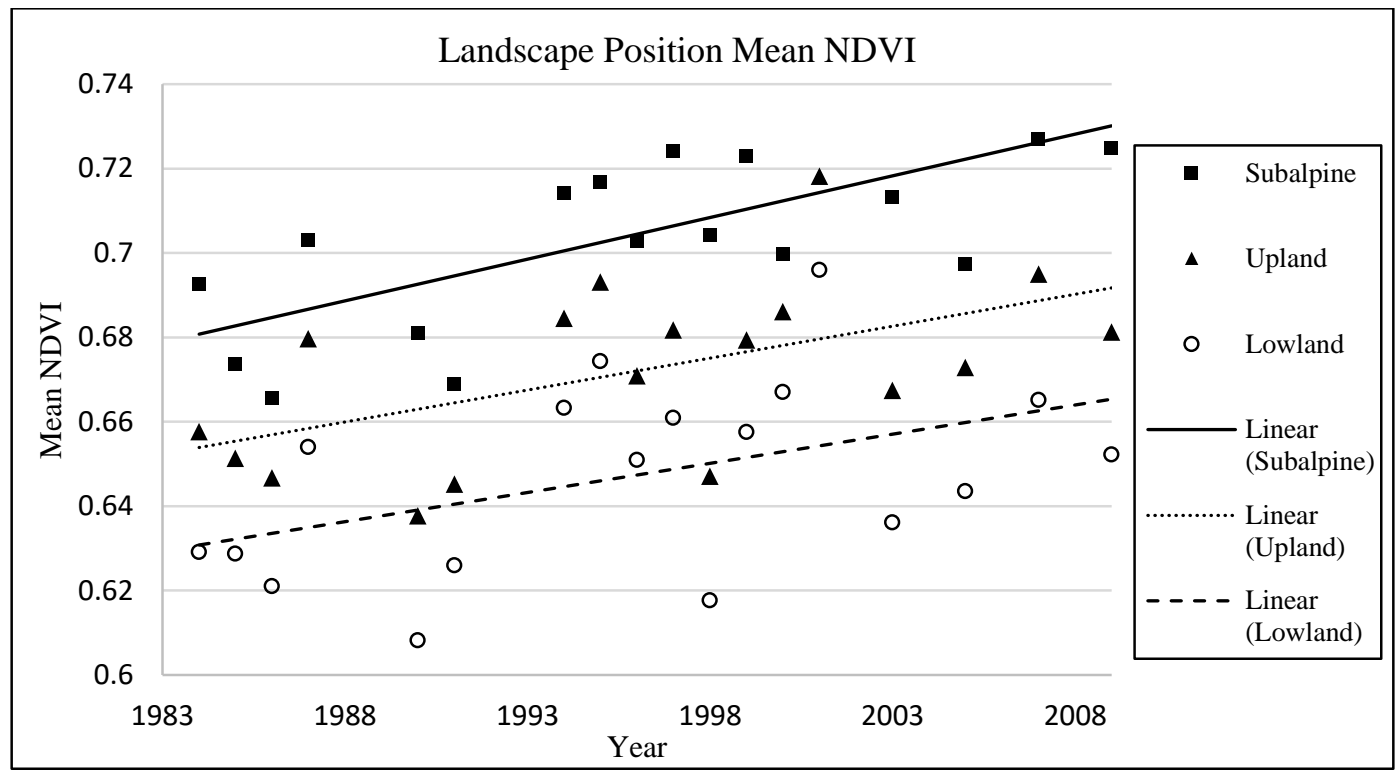

Figure 3.9: 1984-2009 NDVI trend within landscape position classes: subalpine, upland and lowland.

\section{Aspect Positions}

North-facing slopes, and slopes without aspect, revealed significant greening. No trend was found on south-facing slopes. Greatest to smallest mean NDVI values were north-facing, south-facing, and slopes without aspect, respectively (Figure 3.10). 


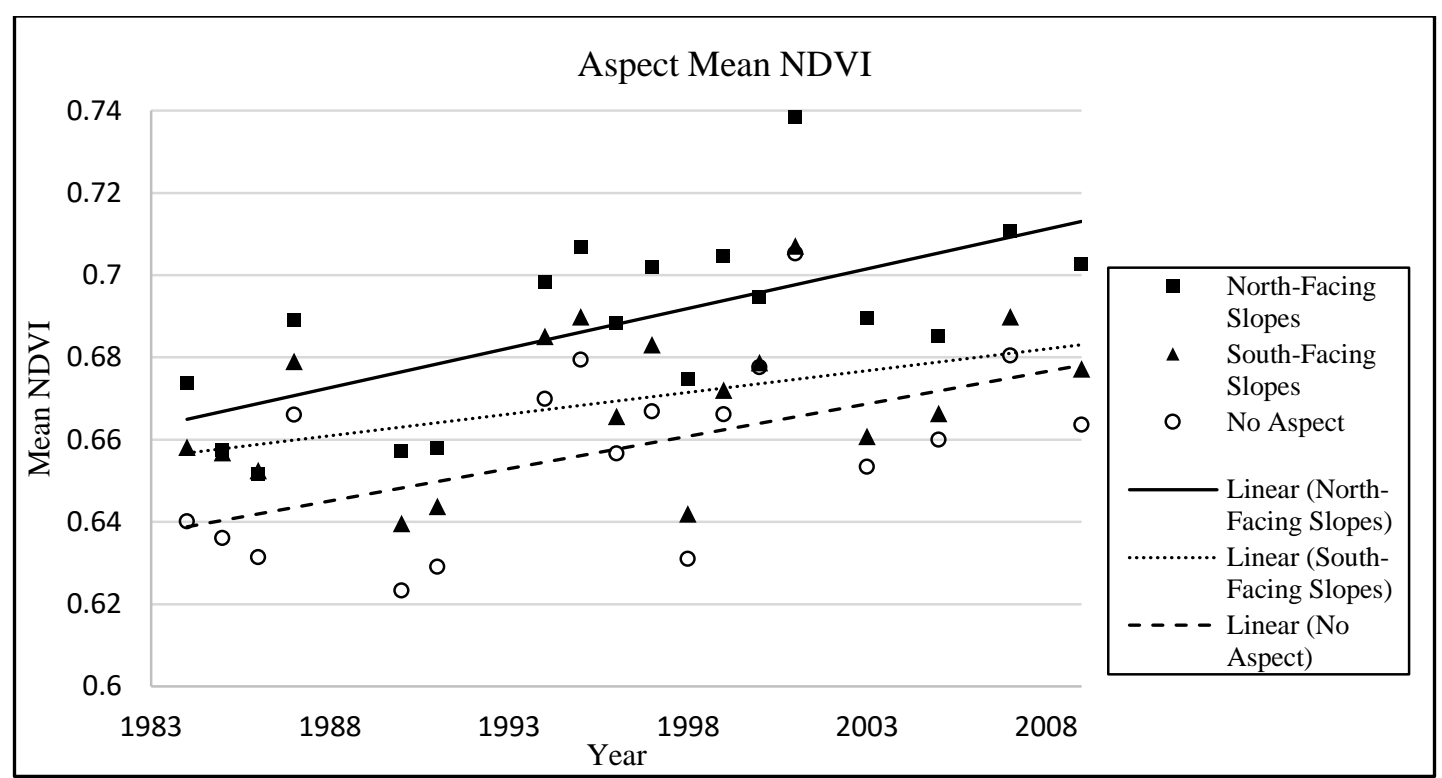

Figure 3.10: 1984-2009 NDVI trend associated with landscape aspect classes.

\section{Burn Areas}

Burn area polygons were investigated individually. The 1958 burn area displayed consistent recovery as evidenced by significant greening trends from 1984 to 2009 . When examining post burn NDVI values, the 1991 burn recovery had the steepest slope (0.008 NDVI units per year) and the highest $\mathrm{R}^{2}(0.76)$ of any landscape unit class investigated. Pre-burn values are consistent with greening trends in other landscape units (Figure 3.11). 


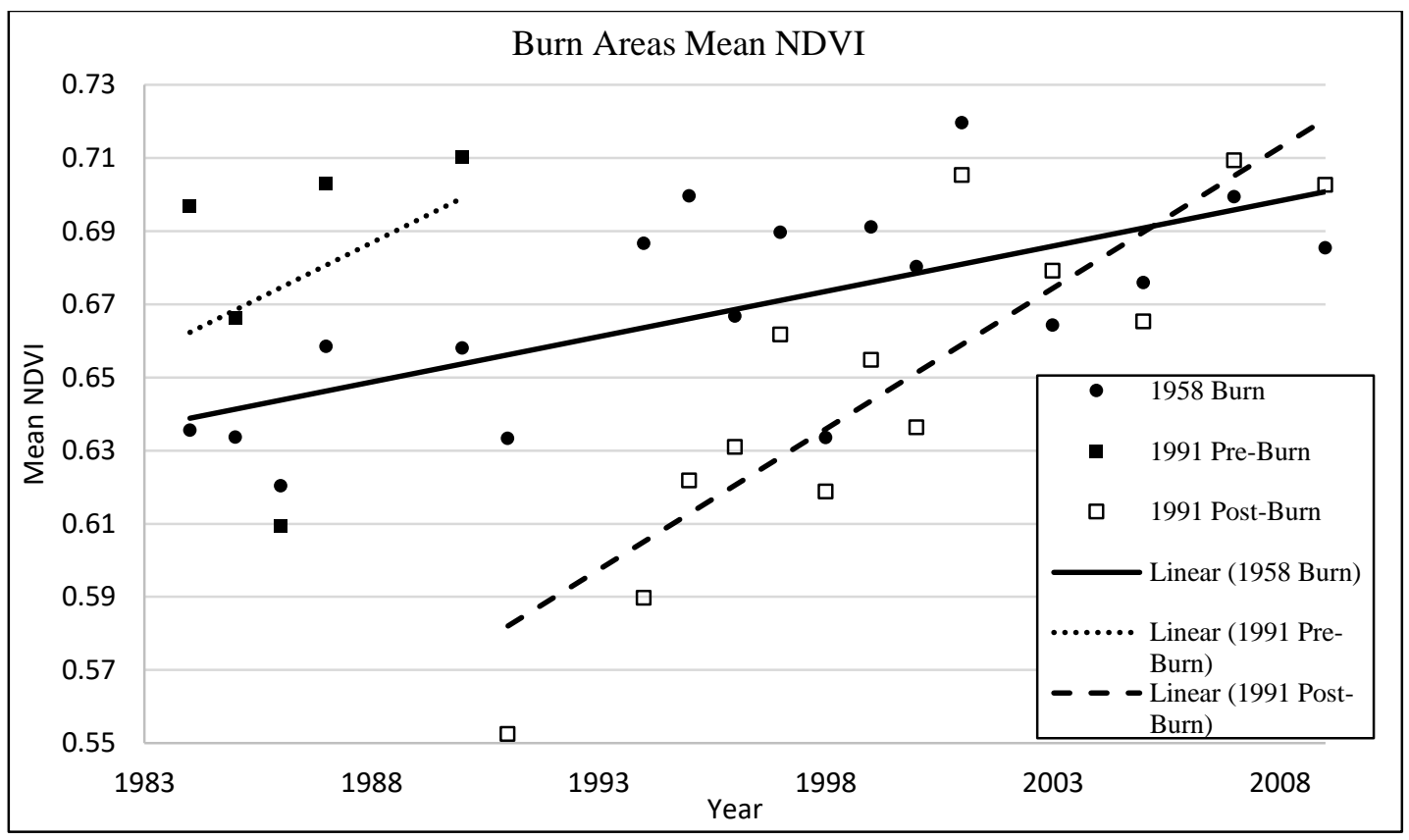

Figure 3.11: 1984-2009 NDVI trend within burn area classes.

\subsubsection{Pixel-wise NDVI Trends for Leading Species Classes}

Significant greening trends were found in all leading species classes; as well, several leading species displayed some browning (Figure 3.12). The deciduous tree grouping showed both greening and browning trends. When further sorted into species, balsam poplar and birch revealed a majority of greening pixels; $70 \%$ and 56\%, respectively. Trembling aspen showed the least greening (21\%) and most browning (4\%) per species class and all other landscape units. Lodgepole pine pixels showed moderate greening trends (33\%). Subalpine fir had extensive greening $(48 \%)$. White spruce, the most abundant and spatially extensive tree within the study area, displayed both greening and browning trends. When further stratified by landscape position, it was found that most browning trends occurred mostly in lowland white spruce (2\%) and upland white spruce (1\%) dominant areas. In contrast, a large percentage of upland white spruce experienced greening (54\%). 


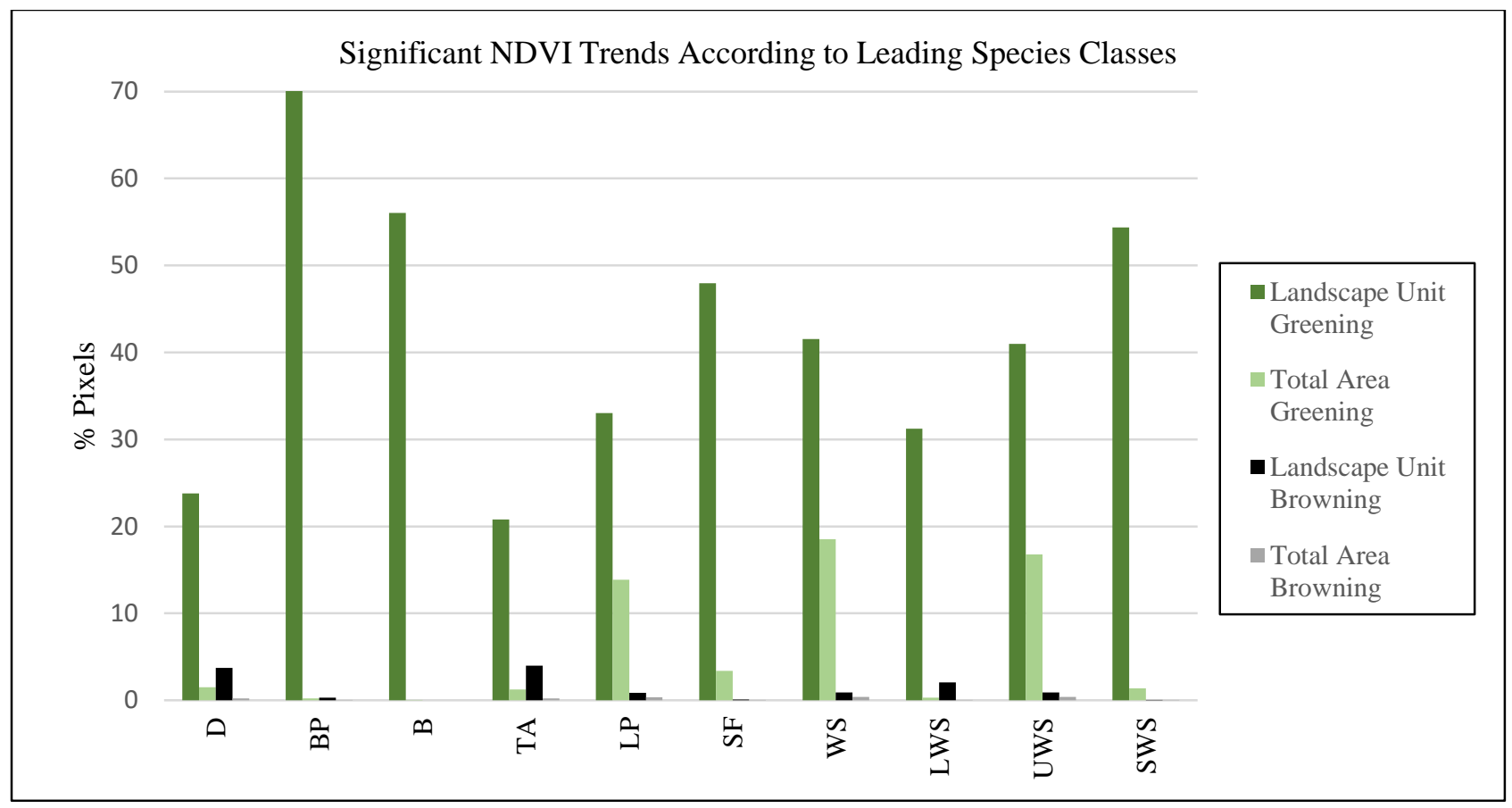

Figure 3.12: Percentage of pixels with significant NDVI trends across leading species classes. Percentages were calculated for individual landscape units, and by total area. Codes for leading species classes are: $\mathrm{D}=$ deciduous, $\mathrm{BP}=$ balsam poplar, $\mathrm{B}=$ birch, $\mathrm{TA}=$ trembling aspen, $\mathrm{LP}=$ lodgepole pine, $\mathrm{SF}=$ subalpine fir, $\mathrm{WS}$ $=$ white spruce, $\mathrm{LWS}=$ lowland white spruce, $\mathrm{UWS}=$ upland white spruce, $\mathrm{SWS}=$ subalpine white spruce.

\subsubsection{Linear Regression for Leading Species Classes}

Within the Whitehorse study area balsam poplar, birch, lodgepole pine, subalpine fir and white spruce had similar increasing trends in NDVI (Table 3.7). Trembling aspen experienced no significant trend. Similarly, the deciduous species classes consisting of an amalgamation of broad-leaved species classes (balsam poplar, birch and trembling aspen) had no specific trend, due to the disproportionate influence of trembling aspen. Additionally, white spruce was further stratified by landscape position. Upland and subalpine white spruce had a strong greening trend, while no significant trend was found in lowland white spruce. 
Table 3.7: 1984-2009 leading species description and linear regression findings for association with NDVI.

\begin{tabular}{lllllll}
\hline Leading Species & Hectares & Pixel Count & Mean & $\mathrm{r}^{2}$ & Slope & $p$ value \\
\hline Deciduous & 1836 & 20390 & 0.71 & 0.10 & 0.001 & 0.196 \\
Balsam Poplar & 85 & 952 & 0.73 & 0.48 & 0.002 & $0.001^{* * *}$ \\
Birch & 33 & 370 & 0.71 & 0.48 & 0.002 & $0.001^{* * *}$ \\
Trembling Aspen & 1717 & 19081 & 0.70 & 0.07 & 0.001 & 0.272 \\
Lodgepole Pine & 12117 & 134603 & 0.66 & 0.28 & 0.002 & $0.023^{*}$ \\
Subalpine Fir & 2035 & 22618 & 0.71 & 0.39 & 0.002 & $0.005^{* *}$ \\
White Spruce & 12845 & 142619 & 0.68 & 0.39 & 0.002 & $0.006^{* *}$ \\
Lowland White Spruce & 294 & 3263 & 0.65 & 0.20 & 0.001 & 0.062 \\
Upland White Spruce & 11810 & 131283 & 0.67 & 0.38 & 0.002 & $0.006^{* *}$ \\
Subalpine White Spruce & 740 & 8251 & 0.71 & 0.41 & 0.002 & $0.004^{* *}$ \\
\hline
\end{tabular}

\subsubsection{Pixel-wise NDVI Trends for Management Strata}

Greening and browning trends occurred across management strata (Figure 3.13). Spruce $(48 \%)$ and fir mix $(51 \%)$ had the greatest number of significant greening pixels. Management strata with deciduous components all exhibited sizeable browning compared to other strata: deciduous (5\%), deciduous/pine (3\%), deciduous/spruce (3\%), pine/deciduous (1\%) and spruce/deciduous (2\%). This may have been influenced by the most prolific deciduous tree in the study area, trembling aspen. 


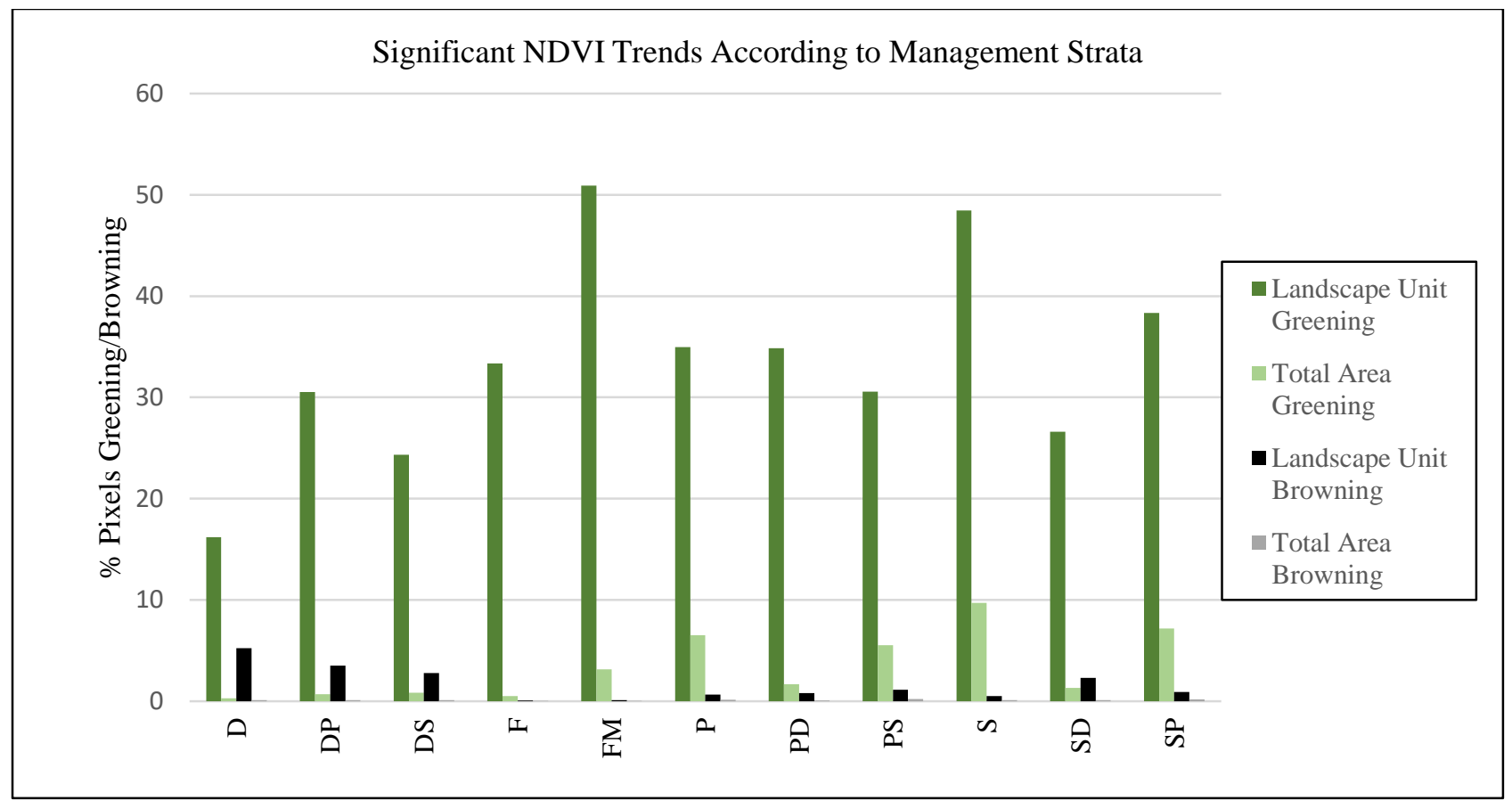

Figure 3.13: Percentage of pixels with significant NDVI trends across management strata. Percentages were calculated for percentage of pixels by individual landscape units and by total area. Codes for management strata are: $\mathrm{D}=$ deciduous, $\mathrm{DP}=$ deciduous/pine, $\mathrm{DS}=$ deciduous/spruce, $\mathrm{F}=$ fir, $\mathrm{FM}=$ fir mix, $\mathrm{P}=$ pine, $\mathrm{PD}=$ pine/deciduous, $\mathrm{PS}=$ pine/spruce, $\mathrm{S}=$ spruce, $\mathrm{SD}=$ spruce deciduous and $\mathrm{SP}=$ spruce pine.

\subsubsection{Linear Regression for Management Strata}

All classes without a deciduous component had significant positive greening trends

(Table 3.8). Deciduous management strata were strongly influenced by the abundance of trembling aspen, which is the most frequently occurring broadleaf tree species in the study area. Management strata with strong deciduous component displayed a higher mean NDVI. Spruce $\left(\mathrm{r}^{2}\right.$ $=0.45)$, Fix Mix $\left(r^{2}=0.42\right)$, and Spruce Pine $\left(r^{2}=0.36\right)$ had the strongest correlations. 
Table 3.8: 1984-2009 linear regression for NDVI within management strata.

\begin{tabular}{lllllll}
\hline Strata Name & Hectares & Pixel Count & Mean & $\mathbf{r}^{\mathbf{2}}$ & Slope & $\boldsymbol{p}$ value \\
\hline Deciduous & 471 & 5234 & 0.72 & 0.03 & 0.000 & 0.484 \\
Deciduous Pine & 628 & 6969 & 0.72 & 0.16 & 0.001 & 0.103 \\
Deciduous Spruce & 984 & 10968 & 0.70 & 0.13 & 0.001 & 0.147 \\
Fir & 439 & 4883 & 0.68 & 0.26 & 0.002 & $0.031^{*}$ \\
Fir Mix & 1783 & 19801 & 0.72 & 0.42 & 0.002 & $0.004^{* *}$ \\
Pine & 5376 & 59718 & 0.66 & 0.31 & 0.002 & $0.017^{*}$ \\
Pine Deciduous & 1377 & 15268 & 0.67 & 0.28 & 0.002 & $0.024^{*}$ \\
Pine Spruce & 5204 & 57833 & 0.67 & 0.25 & 0.001 & $0.034^{*}$ \\
Spruce & 5775 & 64153 & 0.68 & 0.45 & 0.002 & $0.002^{* *}$ \\
Spruce Deciduous & 1392 & 15464 & 0.66 & 0.18 & 0.001 & 0.076 \\
Spruce Pine & 5403 & 59952 & 0.67 & 0.36 & 0.002 & $0.009^{* *}$ \\
\hline
\end{tabular}

\subsubsection{Pixel-wise NDVI Trends for Soil Moisture Regimes}

Greening trends were found in all soil moisture regime classes and browning trends were dispersed sporadically across dry to very wet areas (Figure 3.14). Moderately dry to very fresh areas constituted the largest part of the study area. Dry soils had the least number of greening pixels (20\%) and the most browning pixels (2\%). Moist (50\%), very moist (60\%) and moderately wet $(55 \%)$ areas displayed sizable quantities of greening pixels by landscape unit. These are soils that are not saturated but can retain moisture after rainfall. 


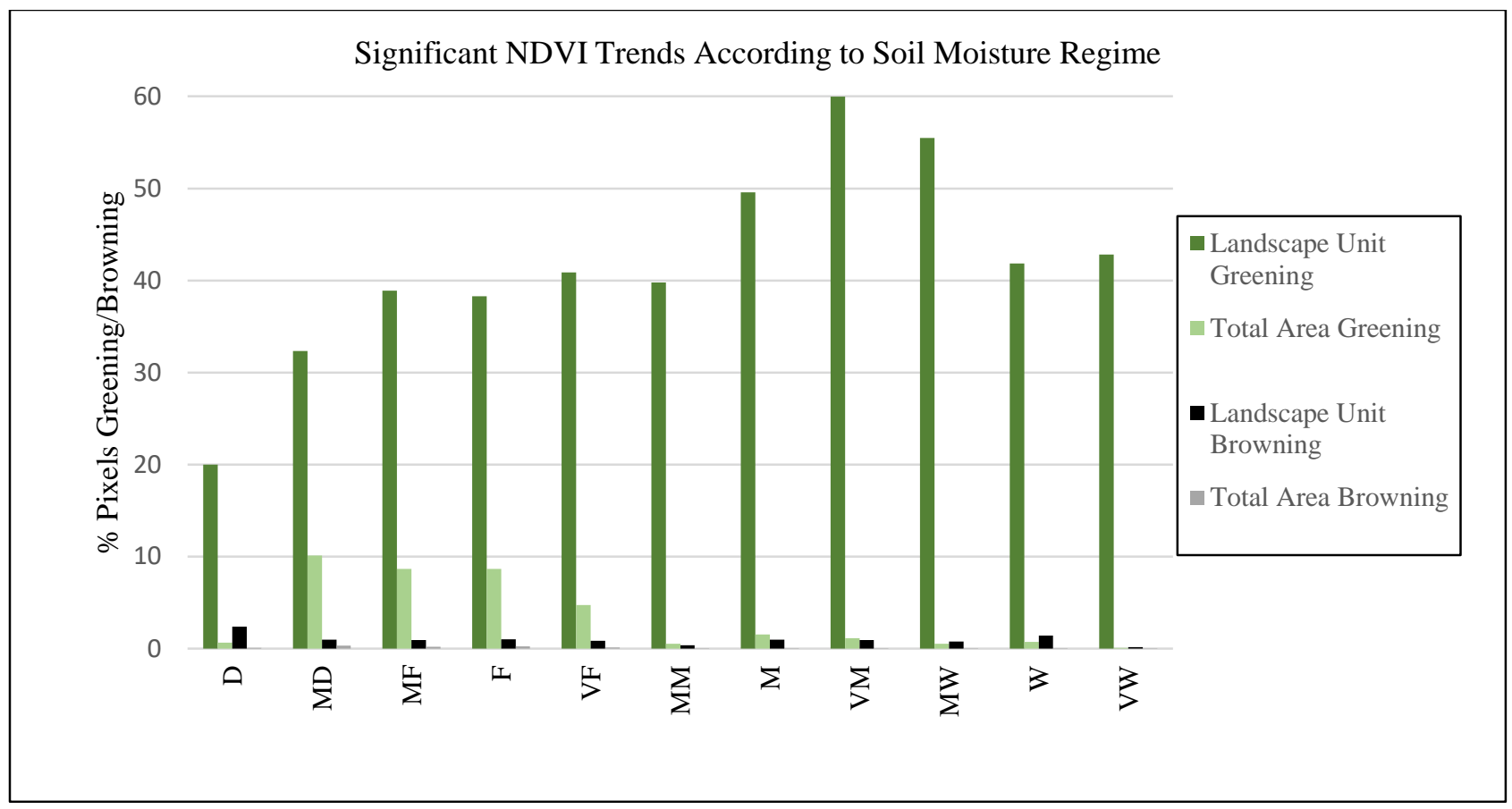

Figure 3.14: Percentage of pixels with significant NDVI trends across soil moisture regimes. Percentages were calculated for percentage of pixels by individual landscape units and by total area. Codes for soil moisture regime are: $\mathrm{D}=$ dry, $\mathrm{MD}=$ moderately dry, $\mathrm{MF}=$ moderately fresh, $\mathrm{F}=$ fresh, $\mathrm{VF}=$ very fresh, $\mathrm{MM}=$ moderately moist, $\mathrm{M}=$ moist, $\mathrm{VM}=$ very moist, $\mathrm{MW}=$ moderately wet, $\mathrm{W}=$ wet and $\mathrm{VW}=$ very wet.

\subsubsection{Linear Regression for Soil Moisture Regimes}

Soil moisture regime was the best predictor of mean NDVI among landscape units (Table

3.9). The dry class had the only non-significant greening trend. This points to the importance of available soil moisture for plant growth.

Table 3.9: 1984-2009 linear regression for NDVI according to soil moisture regime

\begin{tabular}{lllllll}
\hline \multicolumn{1}{c}{ Soil Moisture Regime } & Hectares & Pixel Count & Mean & $\mathrm{r}^{2}$ & Slope & $p$ value \\
\hline Dry & 902 & 10022 & 0.62 & 0.16 & 0.001 & 0.097 \\
Moderately Dry & 9026 & 100247 & 0.67 & 0.28 & 0.001 & $0.024^{*}$ \\
Moderately Fresh & 6433 & 71440 & 0.68 & 0.35 & 0.002 & $0.010^{* *}$ \\
Fresh & 6510 & 72331 & 0.69 & 0.35 & 0.002 & $0.009^{* *}$ \\
Very Fresh & 3324 & 36893 & 0.68 & 0.34 & 0.002 & $0.010^{* *}$ \\
Moderately Moist & 384 & 4251 & 0.68 & 0.33 & 0.002 & $0.013^{*}$ \\
Moist & 890 & 9872 & 0.69 & 0.42 & 0.002 & $0.004^{* *}$ \\
Very Moist & 3324 & 6097 & 0.68 & 0.48 & 0.002 & $0.001^{* * *}$ \\
Moderately Wet & 263 & 2939 & 0.67 & 0.48 & 0.002 & $0.001^{* * *}$ \\
Wet & 501 & 5552 & 0.64 & 0.37 & 0.002 & $0.008^{* *}$ \\
Very Wet & 54 & 607 & 0.60 & 0.48 & 0.003 & $0.002^{* *}$ \\
\hline
\end{tabular}


Very moist to very wet classes occurred exclusively in upland white spruce areas. Dry soils were dominantly occupied by trembling aspen and pine.

\subsubsection{Forest Disturbance}

The only forest health disturbance abiotic or biotic to make up over $1 \%$ of the study area from the 2009 aerial overview health survey was the aspen serpentine leaf miner-a defoliator of aspen trees. It was most prevalent in deciduous classes covering up to $20 \%$ of the class area

(Table 3.10). Widespread aspen serpentine leaf miner attacks began in the 1990s (Yukon Energy, Mines and Resources, Forest Management Branch, 2009). Forest health reports state it is now rare to find unaffected aspen stands across much of the Yukon.

Gradual biotic disturbances are difficult to detect using remotely sensed data, especially at a spatial resolution of $30 \mathrm{~m}$ a side (Landsat) and even more so when the pest does not result in tree mortality. This is the case for the aspen serpentine leaf miner. The forest overview health survey represents what can be seen with the human eye from a low-flying aircraft. It is probable that it only captured severe disturbances and many remained undetected. Aspen serpentine leaf miner damage is difficult to distinguish in 1984 and 2009 NDVI composites, and in 2009 high spatial resolution aerial photos (Figure 3.15). No defoliation occurred in the 1984 composite, while 2009 had an abundance of aspen leaf miner attacks recorded in the forest health survey.

Defoliation was better detected by comparing Landsat NDVI composites than by examining the single natural colour higher resolution air photo.

Gradual detection of forest disturbance is patchy at best when using bimodal detection techniques. Using an approach that overlaid pixels with significant browning trends on at 2009 air photo, it was shown that browning did occur within the aspen serpentine leaf miner 
disturbance polygons. Still, considerable discrepancy existed between the aerial overview surveys and this study's time series analysis.

Table 3.10: Aspen serpentine leaf miner damage area, and proportion of area affected according to leading species and management strata.

\begin{tabular}{lll}
\hline Polygon Class & Area (ha) & Area affected (\%) \\
\hline Leading Species & & \\
Lodgepole Pine & 768 & 6 \\
Subalpine Fir & 15 & 1 \\
Trembling Aspen & 333 & 19 \\
White Spruce & 539 & 4 \\
\hline Strata & & \\
Deciduous & 98 & 21 \\
Deciduous/Pine & 128 & 20 \\
Deciduous/Spruce & 190 & 19 \\
Pine/Deciduous & 134 & 10 \\
Pine/Spruce & 377 & 7 \\
\hline
\end{tabular}



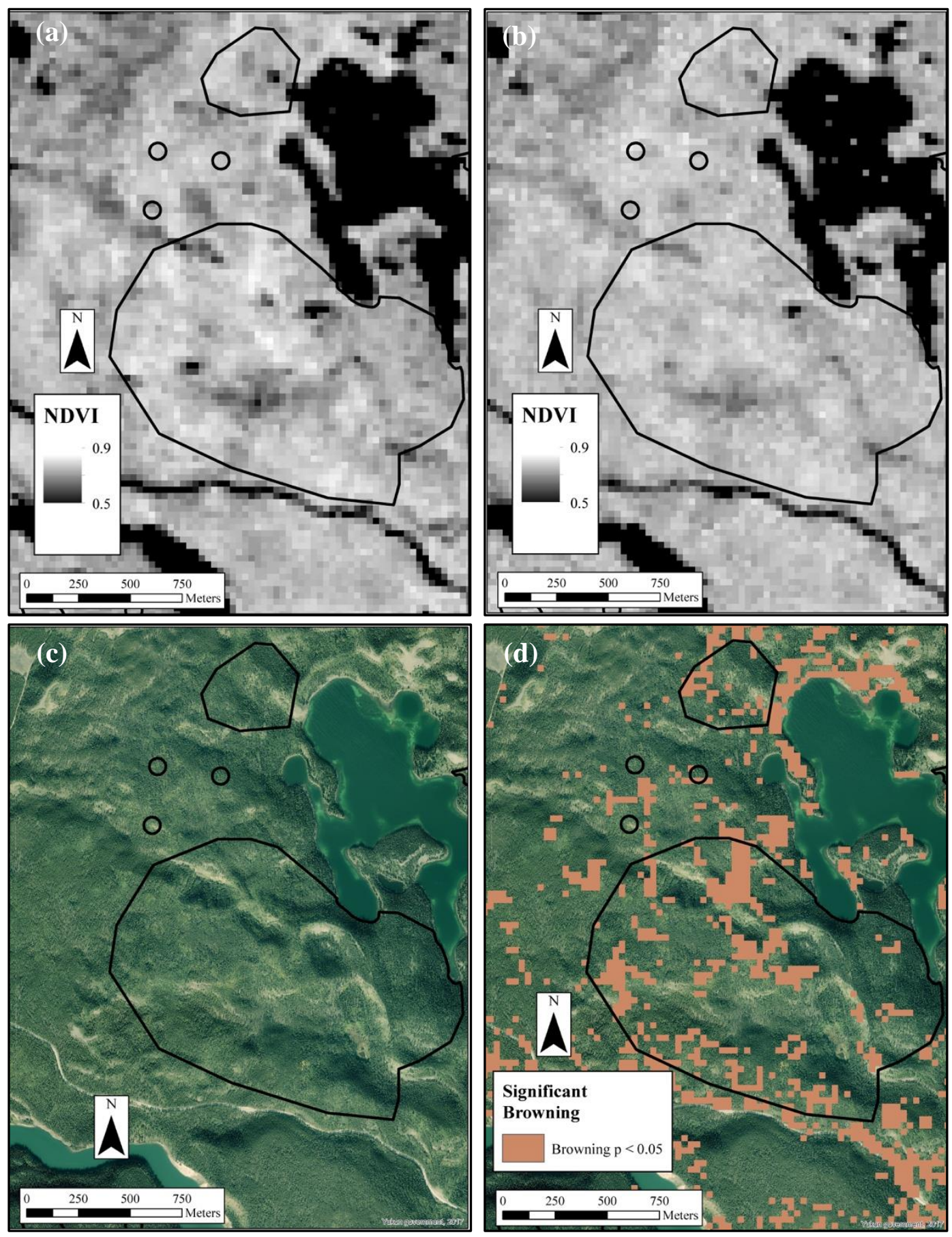

Figure 3.15: Satellite images and air photos depicting aspen serpentine leaf miner damage (Yukon Government aerial overview survey polygons outlined in black). From left to right 1984 NDVI composite (a), 2009 NDVI composite (b), 2009 air photo (c), 2009 air photo with significant pixel browning overlay(d).

\subsubsection{NDVI and Climate Data}

Mean NDVI in all leading species classes reacted similarly to inter-annual climate variability (Table 3.11). Trembling aspen and balsam poplar $(\mathrm{r}=0.54)$ along with trembling 
aspen and subalpine fir $(r=0.58)$ had the lowest correlations. The highest correlations were with White spruce and birch $(r=0.96)$ and white spruce and lodgepole pine $(r=0.95)$.

Table 3.11: Correlation matrix (Pearson's r) for leading species classes. All correlations are significant $(\mathrm{p}<0.05)$.

\begin{tabular}{|c|c|c|c|c|c|c|c|c|c|}
\hline & Balsam & & Trembling & Lodgepole & Subalpine & White & $\begin{array}{l}\text { Lowland } \\
\text { White }\end{array}$ & $\begin{array}{l}\text { Upland } \\
\text { White }\end{array}$ & $\begin{array}{l}\text { Subalpine } \\
\text { White }\end{array}$ \\
\hline Deciduous & Poplar & Birch & Aspen & Pine & Fir & Spruce & Spruce & Spruce & Spruce \\
\hline Deciduous & 0.67 & 0.83 & 0.82 & 0.94 & 0.74 & 0.90 & 0.95 & 0.91 & 0.63 \\
\hline Balsam Poplar & 1.00 & 0.81 & 0.54 & 0.72 & 0.92 & 0.87 & 0.77 & 0.86 & 0.89 \\
\hline Birch & & 1.00 & 0.69 & 0.93 & 0.87 & 0.96 & 0.88 & 0.96 & 0.79 \\
\hline Trembling Aspen & & & 1.00 & 0.77 & 0.58 & 0.77 & 0.74 & 0.77 & 0.60 \\
\hline Lodgepole Pine & & & & 1.00 & 0.81 & 0.95 & 0.95 & 0.96 & 0.70 \\
\hline Subalpine Fir & & & & & 1.00 & 0.91 & 0.84 & 0.91 & 0.90 \\
\hline White Spruce & & & & & & 1.00 & 0.96 & 1.00 & 0.83 \\
\hline Lowland White Spruce & & & & & & & 1.00 & 0.96 & 0.69 \\
\hline Upland White Spruce & & & & & & & & 1.00 & 0.81 \\
\hline Subalpine White & & & & & & & & & \\
\hline Spruce & & & & & & & & & 1.00 \\
\hline
\end{tabular}

A cubic spline was used to investigate the presence of a non-linear relationship between the study area mean annual NDVI and year (Figure 3.16). Knots were selected by referencing climate graphs matching oscillations in NDVI to oscillations in temperature and precipitation (Figure 3.17). Mean annual NDVI values were significantly, and non-linearly, associated with climate $\left(r^{2}=0.89, p<0.005\right)$. Three periods of drought are evident in both the climate graph and the spline graph; 1992, 1998 and 2004. All three periods were historical droughts over the last 67 years. These years are represented as red dots in Figure 3.18. Each year had low precipitation with average to high mean temperatures. 2004 had the highest recorded mean July temperature. 


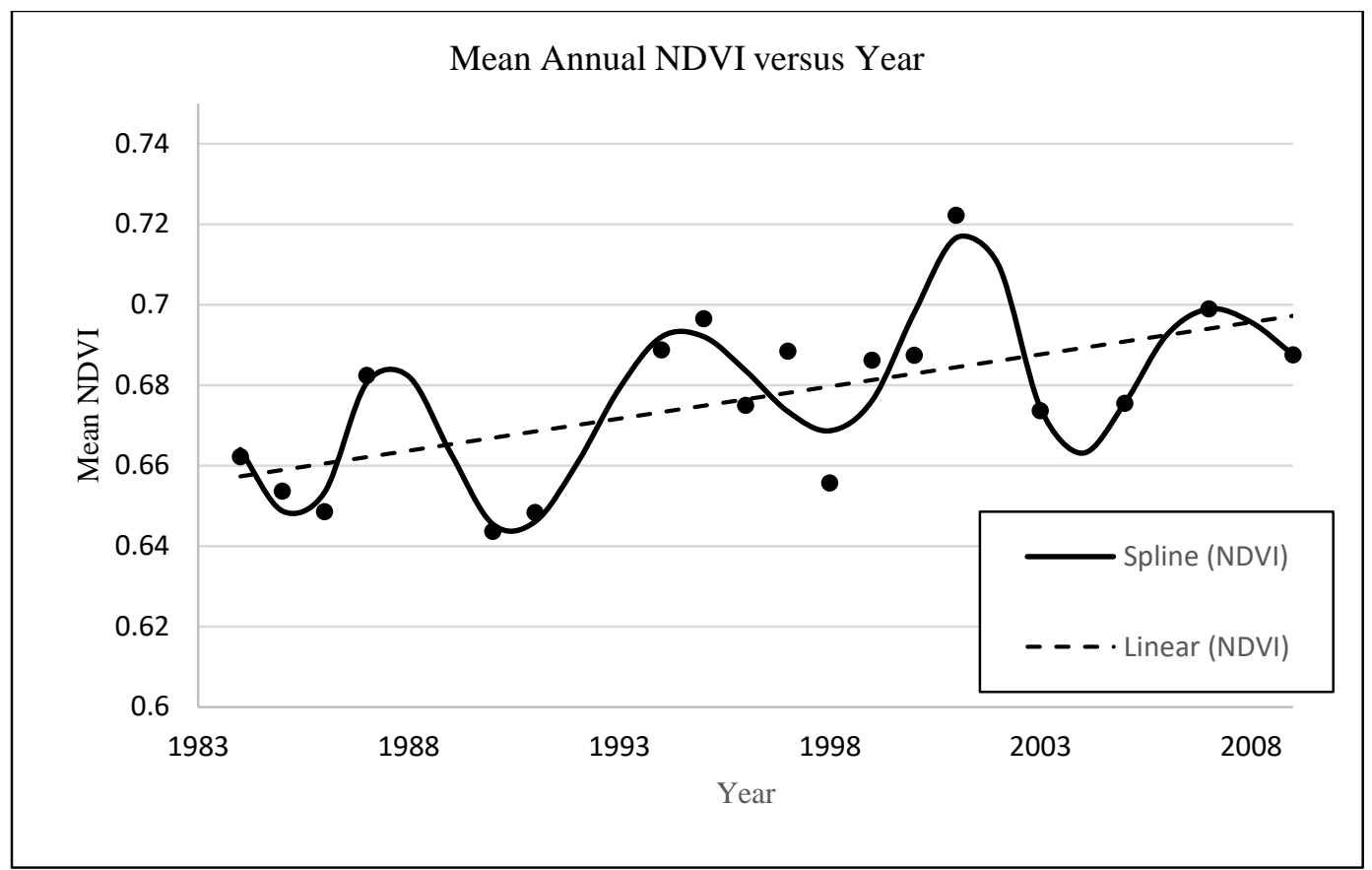

Figure 3.16: Cubic spline fitted through mean annual NDVI versus year for the Whitehorse study area $\left(\mathrm{R}^{2}=89.3, \mathrm{p}<0.005\right.$, F-statistic $=7.415$ on 9 and 8 degrees of freedom $)$.

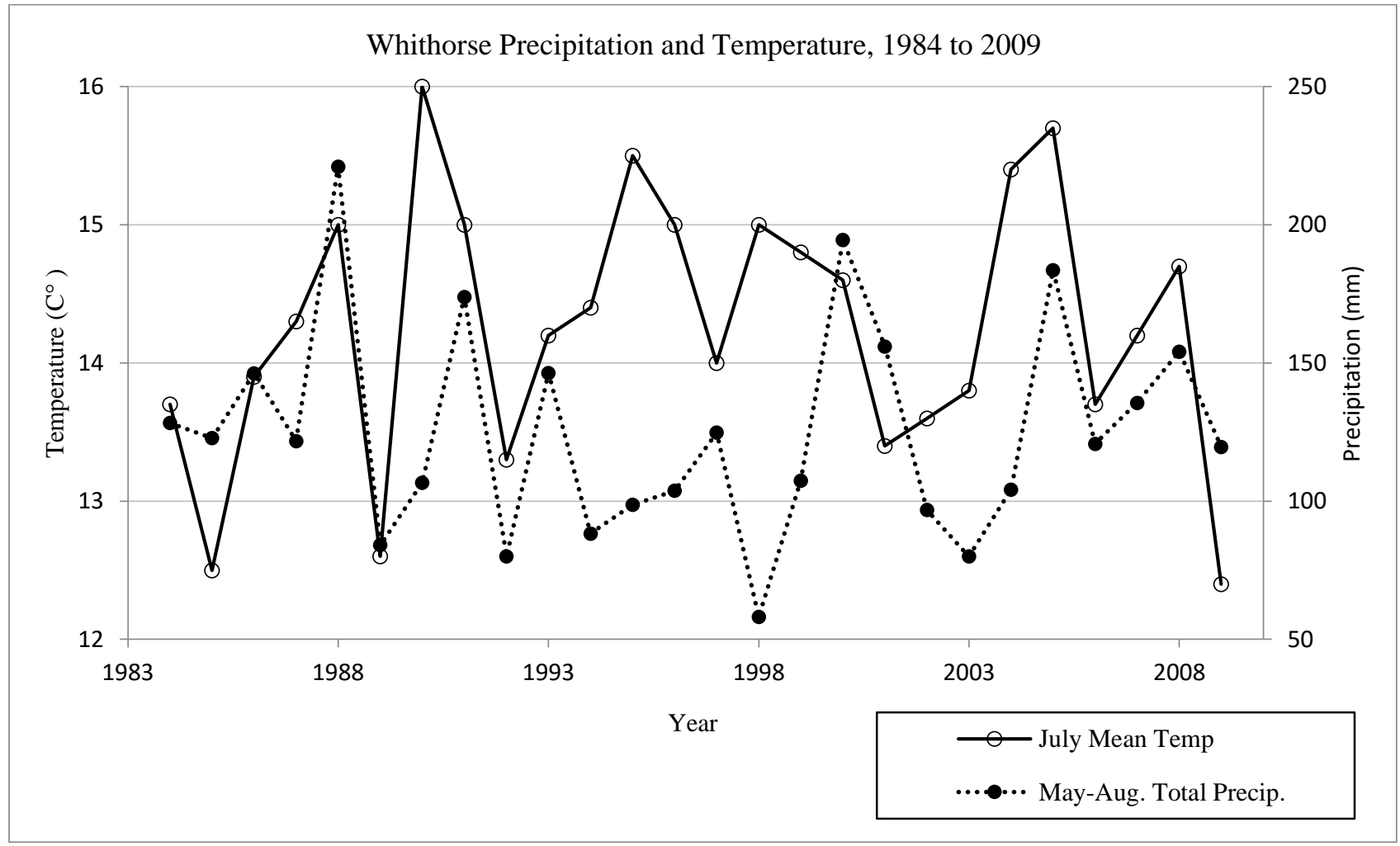

Figure 3.17 Whitehorse July mean temperature $\left(\mathrm{C}^{\circ}\right)$ and summed May to August precipitation $(\mathrm{mm})$, 19842009 (data from Whitehorse International Airport) 


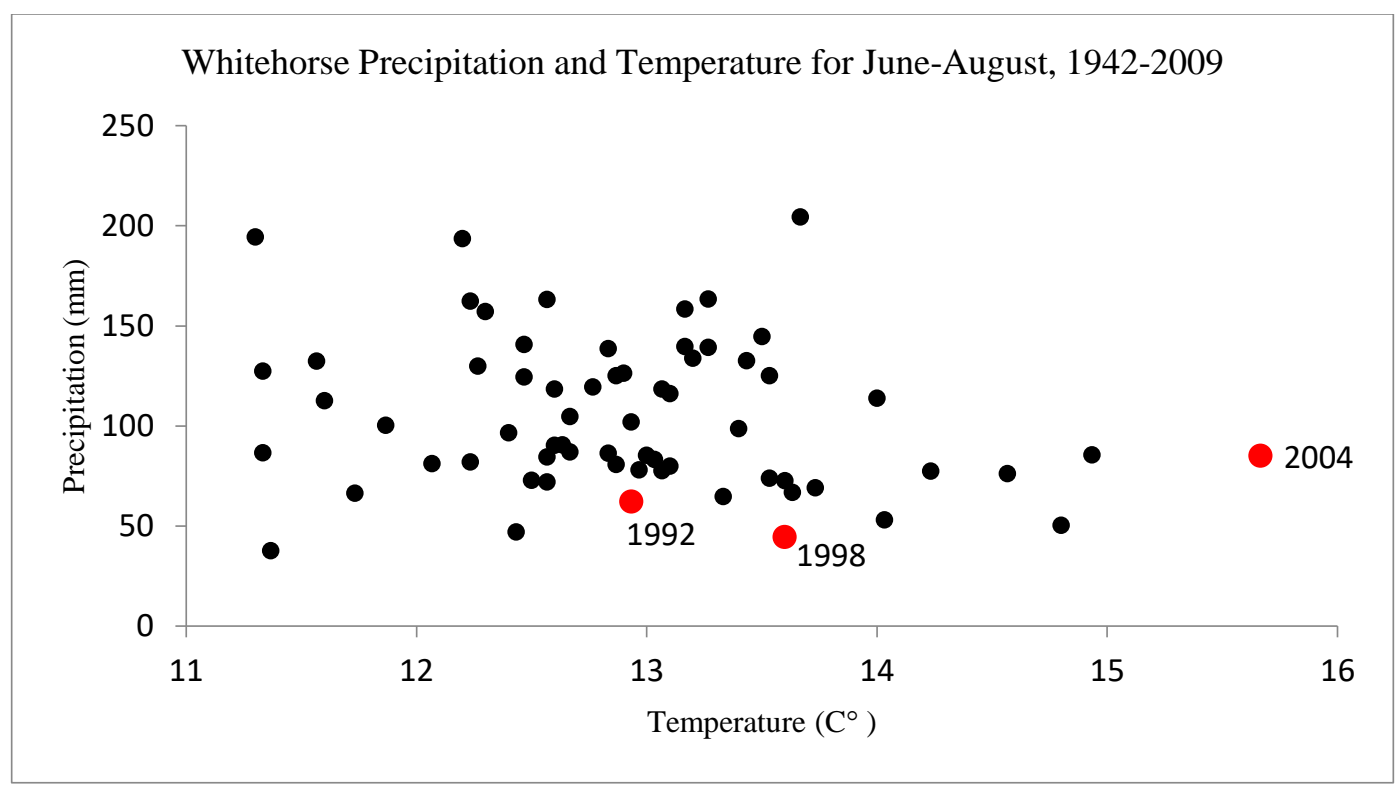

Figure 3.18 Mean June-August temperature versus total precipitation from 1942-2009. Drought years in time series indicated by red dots.

\subsection{Discussion}

Temporal trends in NDVI (proxy for vegetation vigour) vary considerably in northern Canada and Alaska. Regional trends in the boreal forests of interior Alaska have shown declining NDVI values over the past 20-30 years (Goetz et al., 2005; Verbyla et al., 2008; Baird et al., 2012). Regional greening trends in boreal forests and the tundra biome are evident in other parts of Canada and Alaska—particularly in southern Yukon (Ju and Masek, 2016). On a whole, the overall productivity of boreal forests has increased because of a changing climate (Boisvenue and Running, 2006). In the present study, temporal greening trends were expected for the Whitehorse study area. Therefore, the focus of this study was to identify and quantify specific land cover types that showed a greater propensity for greening at the landscape scale. The Whitehorse study area has a variety of vegetation types, landscape positions, aspect positions and disturbances that are representative of the boreal forests of southern Yukon. Moreover, the study area has an abundance of Yukon Government spatial data that was used to both complement detection of, and to explain reasons for, greening trends. Disentangling the nuance of 
contributors to overall greening trends was further aided by detailed government-collected ancillary data.

An important consideration prior to discussing results is that NDVI acts as a crude proxy for vegetation productivity or greenness. Productivity can be derived by many metrics that have unique relationships with NDVI (Peterolli et al., 2005). Leaf area index (LAI) has a linear relationship with NDVI, albeit with differing correlations for conifer and deciduous tree species (Fassnacht et al, 1997; Chen et al., 2005). The linear relationship between LAI and NDVI weakens in extremely arid regions and regions with high biomass (Huete, 1988). Moreover, NDVI saturation occurs in regions of high biomass that can result in weak non-linear relationships between NDVI and measures of productivity (Huete et al., 1997). NDVI is also linearly associated with the fraction of absorbed photosynthetically active radiation (fAPAR) and the subsequent calculation of gross primary productivity and net primary productivity across a range of vegetation types (Fensholt et al., 2004; Huemmrich et al., 2005; Puma et al., 2007). Furthermore, Wang et al. (2004) found a strong linear relationship between NDVI and tree growth using tree ring data. In tundra environments, non-linear correlations have been established between NDVI and above ground biomass (Jia et al., 2003; Epstien et al, 2012). The relationship between NDVI and vegetation productivity is complex. For this study, NDVI is a basic indicator of vigour. Since the study area is neither in a high biomass or extremely arid region, this research assumes a linear relationship between NDVI and forest productivity. However, further research is warranted to confirm the relationship between different productivity metrics and NDVI within various vegetation cover in Whitehorse. 


\subsubsection{Regional NDVI Trends and the Influence of Climate}

An overall greening trend was found in the Whitehorse study area. Trend significance and model slope values were comparable to results reported by Ju and Masek (2016); average rate of change was $\sim+0.002$ to $+0.004 \mathrm{NDVI}$ units/year. These findings are further corroborated by remote sensing studies that have used AVHRR imagery and have shown consistent and broad extent greening across northern Canada and Alaska, including in the Whitehorse area (D'Arrigo et al., 1987; Myneni et al., 1997; Zhou et al., 2001; Goetz et al., 2005; Beck and Goetz, 2011; Guay et al., 2014). Irrespective of land cover and vegetation type, evidence of vegetation greening appears to be ubiquitous in these northern locations. Greening trends and more frequent disturbances will inevitably affect forest resources and industry. Forest management practices need to take an adaptive management approach whereby plans can be modified to reflect geographic shifts in species composition and take advantage of disturbances via salvage harvesting (Ogden and Innes, 2008).

Global climate models identify temperature as a regulating factor on vegetation vigour in high-latitude regions with extreme inter-annual temperature cycles (Nemani et al., 2003); this is especially true of spring temperatures and their impact on frost-free days (Scwartz et al., 2006; Jeong et al., 2011). The Whitehorse study area is a high-latitude semiarid region that has experienced increases in temperature, precipitation and annual number of frost-free days; as such, results of the present study confirm expected increases in forest vigour. Moreover, when using a cubic spline regression and visually selecting knots representative of periods of drought and increased precipitation, mean annual NDVI values were highly correlated with year. Verbyla (2015) reported that drought was the dominant control factor concerning regulation of vegetation 
vigor within interior Alaska, and drought may also be having significant multi-year influence on regional soil moisture.

\subsubsection{Effects of Landscape Positions on NDVI Trends}

Mean annual NDVI increased in landscape unit classes with increasing elevation. Lowland landscape positions typically consist of riparian spruce forests at the latter stages of growth. Human settlement of the Whitehorse valley has likely mitigated wildfire disturbance in lowland forests over the last century. Boreal forests across all landscape positions decrease in productivity through succession; older later stage successional forests photosynthesize less than early successional stage younger forests due to the greater abundance of broadleaved vegetation in young boreal forests (Chapin et al., 2006). Relatively low percentages of greening pixels could be explained by the late successional stage of lowland forests and wildfire prevention. Also, vegetation browning is most likely due to age-related productivity decline and flooding in riparian zones (Yarie et al., 2002). Upland landscape positions covered most of the study area and had prevalent greening, with some modest browning. The upland landscape position included a variety of different forest types. Additional classification explored in other landscape units was used to further identify possible trends. Subalpine areas had the largest percentage of greening pixels of all landscape position classes. Subalpine trends in mean NDVI were strongly predicted by year.

Many studies identify the greening of tundra-shrub land and the forest-tundra ecotone to be occurring along a latitudinal gradient (Jia et al., 2003; McManus et al., 2012; Ju and Masek, 2016). Greening of subalpine environments could be related to an early stage biome shift; the treeline is moving upwards and north (Lloyd and Fastie, 2002; Juday et al., 2015). Furthermore, deciduous woody-shrubs are expanding northwards into tundra as well as experiencing higher 
productivity because of increased temperatures (Sturm et al., 2001, 2005; Tape et al., 2006). In the Whitehorse study area, medium sized shrubs that are prominent on high elevation slopes (Francis et al., 1999) are likely experiencing increased productivity because of increased temperature and precipitation.

\subsubsection{Effects of Aspect on NDVI Trends}

Aspect strongly influences vegetation distribution in Whitehorse, Yukon (Oswald and Brown, 1986). All aspect classes showed significant greening trends. North-facing slopes had the most greening of all aspect classes. North-facing slopes in the study area are characterized by dense vegetation, most commonly white spruce and subalpine fir. Permafrost in the sporadic discontinuous zone, including around Whitehorse, is found on north-facing slopes and in areas of high elevation (Ecoregions Working Group, 2004; Lewkowicz and Ednie, 2004). Permafrost restricts drainage and can therefore influence plant available water and soil moisture making vegetation in permafrost areas more resilient to drought.

Because of these conditions, it was expected that greening trends on south-facing slopes would be somewhat impaired. Study findings confirmed this hypothesis. Among the aspect classes, south-facing slopes had the lowest proportion of greening pixels and were one of the few landscape units with no significant trend. Forests on south-facing slopes are dominated by trembling aspen on dry well-drained soils (Oswald and Brown, 1986). The absence of prolific greening on south-facing slopes is most likely related to a combination of drought and insect disturbance to trembling aspen (Hogg et al., 2002; Wagner and Doak, 2013).

\subsubsection{Burn Area NDVI}

Two forest fires, in 1958 and 1991, occurred in the Whitehorse study area. Both areas experienced a greening trend; especially when examining post burn regeneration only. The 1959 
burn has been characterized by slow regeneration of spruce. Forest cover resembling aspen parkland forests along the northern edge of the Canadian prairies now occupies the area (Hogg and Wein, 2005). Burn (1998) found deepening of the soil active layer and thawing of nearsurface permafrost in the 1958 burn site, when compared to unburnt neighbouring forested areas. Permafrost thawing and increases in fire frequency and severity can lead to changes in species composition (Lantz et al., 2009; Tsuyuzaki et al., 2009). One explanation for the proliferation of trembling aspen at the 1958 burn site is that fire exposes mineral soil, increases the soil active layer depth, and thaws permafrost, thereby favouring the establishment of deciduous species, or even grassland, over conifers (Goetz et al., 2007; Johnstone et al., 2010).

In Alaska, white spruce is replacing black spruce in the absence of permafrost (Wirth $e t$ al., 2008). A shift from white spruce to trembling aspen could explain the abundance of greening pixels in the 1958 burn site (broadleaved tree species typically have higher NDVI values than conifers). The rate of change was +0.002 NDVI units/year suggesting that the 1958 burn has mostly regenerated and is experiencing changes indifferent to the rest of the study area. Within the time series, early stages of forest regeneration were captured in the neighbouring 1991 burn. Strong post-burn greening trends exist within the landscape unit. Signifying an earlier stage of regeneration and proliferation of early successional broadleaved species; the 1991 burn had a high rate of change in NDVI units/year $(+0.008)$.

\subsubsection{Effects of Vegetation on NDVI Trends}

Greening and some browning pixels were found in all leading species and management strata. One caveat of using medium spatial-scale satellite images and landscape unit polygons is that justification of observed trends of specific tree species is not possible, instead assumptions are made about vegetation communities. For example, the resolution of this study limits the 
ability to ascertain whether greening or browning trends is a result of species migration or enhanced productivity of trees or shrubs; this is especially true in open forests and subalpine areas. Investigation into what is occurring within vegetation classes at smaller scales is an important area of future research.

\subsubsection{Conifers}

\section{White Spruce}

White spruce is the dominant tree species in the Whitehorse study area. This tree species has a complex relationship with temperature and precipitation that was exemplified when it was further stratified by landscape position. Lowland positioned white spruce showed a smaller amount of greening compared with its performance in other landscape positions; moreover, no significant greening trend was determined. Lowland spruce forests are typically found in wet riparian areas within the study area. Lloyd and Fastie (2002) state that white spruce, when growing in wet sites, are more resilient to pressure for vegetation community change.

Old-growth white spruce stands in lowland positions most likely surpassed peak productivity long ago. Evidence of white spruce browning may be due to riparian zone flooding, or age-related productivity decline (Yarie et al., 2002). Lowland white spruce occupies wetter sites in riparian areas with ample access to water, thus droughts or any increases in precipitation may have, thus far, had little influence on productivity. Interestingly, an inverse relationship between white spruce and temperature was not found in any of the landscape positions, as has been shown in other parts of Yukon and Alaska (Barber et al., 2000; D'Arrigo et al., 2004; Lloyd and Bunn, 2007). Perhaps, a maximum temperature threshold for white spruce in Whitehorse has yet to be reached, as no negative temperature-growth relationships have been 
established for white spruce in the $20^{\text {th }}$ century across southwest Yukon (Youngblut and Luckman, 2008).

White spruce in upland and subalpine locations revealed overall positive greening trends. Greening intensified from lowland to upland, and to subalpine positions. As was expected, areas on the edge of the white spruce species range benefited most from increased precipitation, temperature and number of frost-free days (Miyamoto et al., 2010; Griesbauer and Green, 2012). Using dendroecological reconstruction techniques, Danby and Hik (2007) found that subalpine white spruce moved upwards in elevation on south-facing sites and increased in stand density on north-facing sites, in response to warming in the $20^{\text {th }}$ century. In the present study, $54 \%$ of subalpine white spruce pixels showed significant greening trends. Research conducted by Juday et al., (2015) suggests that opposite white spruce temperature sensitivity across a longitudinal gradient indicates an early stage biome shift; white spruce's range was expanding attitudinally and northwards, while contracting in more southern warmer regions.

Results are indicative of temperature sensitivity along an altitudinal gradient. Lowland white spruce is experiencing less greening than upland and subalpine white spruce. Furthermore, climate models for southwest Yukon project increased temperature and precipitation that may benefit white spruce growth depending on drought frequency and seasonality of precipitation (Chavardes et al., 2013). Precipitation and drought are the primary limiting factors in radial white spruce growth in southern Yukon (Hogg and Wein, 2005; Miyamoto et al., 2010; Griesbauer and Green, 2012). Similar findings have been observed in the boreal forest of Alberta (Chen et al., 2017). The abundant presence of white spruce in the study most likely had strong influences on the overall spline regression findings. Like white spruce, NDVI values throughout the time-series displayed sensitivity to precipitation and drought. Chavardes et al. (2012) warn 
that increases in precipitation and temperature have also benefited disturbance agents like the spruce bark beetle that will most likely increase in frequency and severity.

\section{Lodgepole Pine}

Significant greening trends were observed in lodgepole pine leading species and management strata; however, trends were less pronounced than in other conifer classes. Lodgepole pine is a relatively new tree species to Yukon arriving 7,000 to 10,000 years before present (Strong and Hills, 2013). Lodgepole pines northern most extent lies several hundred kilometers north of the Whitehorse study area (Cwynar and MacDonald, 1987). Both lodgepole pine and white spruce can dominate mature sites in the Whitehorse study area (Oswald and Brown, 1986). However, lodgepole pine typically establishes canopy dominance prior to white spruce because of higher growth rates when young (Eis et al., 1982; Gutsell and Johnson, 2002). A stand survey at the northern most lodgepole pine extent showed that it was increasingly dominant following fire, although within its interior range there was no directional shift of postfire conifer composition, even in stands with low lodgepole pine abundance (Johnstone and Chapine, 2003). Instead post-fire composition is determined by site and environmental variables (Oswald and Brown, 1990).

Johnstone and Chapine (2003) determined that the northern extent of lodgepole pine is not limited by climate influences. Their findings indicate that lodgepole pine is more insulated from the effects of increased precipitation and temperature in the Whitehorse area, when compared with other conifers. Investigating lodgepole pine distributions and climate relationships with remotely sensed data is an important area of future study. Recent remote sensing studies concerning lodgepole pine have focused on the mountain pine beetle (Franklin $e t$ al., 2003; Coops et al., 2009; Senf et al., 2015). Depending on future climate scenarios, the 
mountain pine beetle has the potential to expand into the Whitehorse study area (Safranyik et al., 2010).

\section{Subalpine Fir}

Leading species and strata landscape units had strong positive trends toward increasing NDVI values, both when extracting mean values from the zonal areas, and when examining significant pixel counts. In general, trees are migrating upward in latitude and elevation in the Arctic and Subarctic, thus contributing to a climate-induced biome shift (Grace et al., 2002). In the present study, it was expected that pronounced changes in treeline ecotones would be observed at species' physiological limits (Wookey et al., 2009). In Whitehorse, subalpine fir forests exist on high elevation sites close to treeline. Like white spruce, the relationship between subalpine fir and climate is complex; responses to climate change may be spatially variable and dependent on specific site conditions and on elevation (Spletcha et al., 2000; Peterson et al., 2002). Miyamoto et al. (2010) reported that subalpine fir presence was negatively correlated with temperature at low elevation, and positively correlated with temperature at high elevation sites.

Some research has found similar growth responses to climate between white spruce and subalpine fir because, in contrast with lodgepole pine, both white spruce and subalpine fir species prefer cool-wet sites, exhibit greater shade tolerance and form latter successional stage forests (Green 2005; 2007). The current study determined that greening was present in $48 \%$ of subalpine fir pixels, and 54\% of subalpine white spruce pixels, when analyzed within leading species classes. In management strata, fir pixels showed greening in $33 \%$ of pixels, while the fir mix class pixels (where white spruce or lodgepole pine is a secondary species) displayed a $51 \%$ greening of pixels. These findings suggest that the presence of white spruce is revealing of even 
more greening, whereby white spruce may be more reactive to climate influences than subalpine fir in Whitehorse.

Other studies attribute greening trends to climate-induced shrub responses in foresttundra ecotones (Sturm et al., 2001; Sturm et al., 2005; Jia et al., 2009). Shrubs at tundra-forest ecotones are expected to increase in density and move upwards in latitude and elevation (MyersSmith, et al 2011). Within the Whitehorse study area, subalpine fir occurs usually as open forest with woody shrubs, graminoids, bryophytes, and lichens occupying spaces between trees (Oswald and Brown, 1986). Although Landsat spatial and spectral resolution limit the ability to differentiate between shrubs and trees, shrubs likely played an important role in all subalpine greening within Whitehorse. Moreover, greening attributable to shrubs may have been dampened by tree shadows that have been shown to have a negative influence on accurate NDVI determination in low density coniferous and subalpine forest (McDonald et al., 1998; Rees et al., 2002).

\subsubsection{Deciduous}

\section{Balsam Poplar and Birch}

Both balsam poplar and birch leading species classes had overall strong positive greening trends and large proportions of greening pixels, $70 \%$ and 56\%, respectively. However, these species represent small portions of the overall Whitehorse study area as contiguous forest, 85 ha and 33 ha, respectively. Balsam poplar is generally restricted to alluvial terraces and birch only exists in scattered pockets, thus they rarely form complete stands within the study area (Oswald and Brown, 1987). Balsam poplar has displayed prominent adaptive variation in physiology and phenology in regard to climate influences (Keller et al., 2011; Olson et al., 2013). Also, it has been shown to occupy disturbed sites at higher ratios than spruce in southwest Yukon (Paudel et 
al., 2015). Because balsam poplar occupies cooler well-drained sites, it has likely benefited from increased precipitation in the study area. Influences from increased temperature and drought are mitigated by its resiliency. The relationship between growth and precipitation is positive for birch; however, correlations between growth and temperature are site-specific and dependent upon environmental conditions (Malmstrom et al., 1997; D’Arrigo et al., 2000; Kharuk et al., 2013).

\section{Trembling Aspen}

Trembling aspen had the smallest proportion of greening pixels, and did not exhibit a significant greening trend based upon mean NDVI values. This tree species had the greatest percentage of browning pixels of any leading species class. Moreover, all management strata with deciduous (trembling aspen) components had smaller proportions of greening pixels and greater proportions of browning pixels than management strata without aspen.

Some research suggests that near the southern extent of the boreal forest, boreal conifers may be extirpated and replaced by more tolerant tree species (McKenny et al., 2007; 2011). Recent studies indicate the prevalence of trembling aspen, over white spruce, following fire and insect disturbance (Hogg and Wein, 2005; Johnstone et al., 2010; Paudel et al., 2015). In areas experiencing more precipitation, trembling aspen is encroaching on grasslands (Conway and Danby, 2014). In contrast, the work of Hogg and Hurdle (1995) propose a climate-driven transition from boreal forests to aspen parkland in areas that are projected to get warmer and drier.

Findings from the present research suggest two explanations for the observed response of trembling aspen vigour (as evidenced by greening/browning) over time: (1) insect disturbance, and (2) die-back. The aspen serpentine leaf miner first appeared in Yukon in the early 1980s. The 
appearance of aspen serpentine leaf miner in Yukon forest health reports first occurred in 1987 (Turnquist, 1987), while the pest was first recorded along the Alaska highway in the 1950s and a widespread outbreak began in the 1990s (Yukon Energy, Mines and Resources, Forest Management Branch, 2015).

Aspen serpentine leaf miner activity declined across the Yukon from 2011 to 2015 (Yukon Energy, Mines and Resources, Forest Management Branch, 2015). Although aspen leaf miner activity does not often result in tree mortality (Wagner et al., 2008), it has been shown to have strong negative effects on aspen development and production of aboveground tissue (Wagner and Doak, 2013). Thus, aspen leaf miner activity will influence NDVI values. In the current study, it was assumed that any increase in plant vigour experienced by trembling aspen from increased precipitation and temperature was offset by insect disturbance.

Trembling aspen stands have experienced severe and broad extent die-back in southern boreal forests because of drought (Hogg et al., 2002; Michaelin et al., 2011). Though, aspen dieback is restricted to small patches on south facing slopes in Yukon (Yukon Energy, Mines and Resources, Forest Management Branch, 2015). Trembling aspen often occur on steep rocky south-facing slopes resulting in deformed or stunted trees (Oswald and Brown, 1987). Subtle increases in precipitation were likely moderated by increasing temperature and evapotranspiration demand on the warmest sites with well-drained soils (Price et al., 2013). Trembling aspen on less hospitable sites may have experienced droughts more intensely. Even if mortality did not occur, this would be reflected in NDVI values.

\subsubsection{Effects of Soil Moisture Regime on NDVI Trends}

Greening trends associated with soil moisture classes agreed with those determined for leading species and management strata. The highest percentage of greening pixels per soil 
moisture regime classes were found in moist, very moist and moderately wet classes. Greening pixels declined as soil moisture increased and decreased outside of moist, very moist, and moderately wet soil moisture classes. White spruce and subalpine fir are the dominant trees species on moist to moderately moist classes. As confirmation for soil moisture as a reason for aspen dieback, the dry soil moisture regime class, commonly occupied by trembling aspen, had $2 \%$ browning pixels. Despite increasing forest vulnerability to greater intensity droughts (Anderegg et al., 2013; Allen et al., 2015), the adverse influence of hotter weather has yet to substantially impact vegetation across even the driest soil moisture regimes within Whitehorse, Yukon. Rather, the study area has experience greening or increased forest vigour, in lieu of disturbance, as has been described in continental and global scale studies (see Myneni et al., 1997; Ju and Masek 2012). This suggests that evapotranspiration demand has not annulled the influence of increased precipitation and longer growing seasons. Although, further increases in temperature and precipitation could potentially be detrimental to boreal plants, because atmospheric moisture demand (vapour pressure deficit) increases nonlinearly with temperature, such that subtle rises in temperature can result in larger evapotranspiration demand (Williams et al., 2012; Besmears et al., 2013; Eamus et al., 2013;).

\subsubsection{Uncertainties and Limitations}

The Landsat satellite archive has proven to be an invaluable tool for spatial and temporal ecological investigations (Cohen and Goward, 2004; Loveland and Dwer 2012; Wulder et al., 2012; Kennedy et al., 2014; Turner et al., 2015; Pasquarella et al., 2016). Despite recent advancements, uncertainties remain in the application of Landsat data to ecological monitoring (Wulder et al., 2008a); within which this current study's findings are included. Concerns include image collection (Banskota et al., 2014), spatial resolution (Townshend and Justice, 1988), inter 
and intra-sensor calibration (Wulder et al., 2008b; Sulla-Menashe et al., 2016; Zhang et al., 2016), and differences in time-series change detection algorithms (Cohen et al., 2016).

The temporal distribution of available, and usable, Landsat scenes was strongly influenced by cloud cover and smoke. Also, a scan line corrector failure in May 2003 limited useful Landsat 7 ETM+ to the years from 1999 to 2002. To accommodate uncertainties regarding image selection, this study used a greenest annual pixel approach with NDVI (Roy et al., 2012) for a phenology window ranging from June $20^{\text {th }}$ to July $31^{\text {st }}$ (Baird et al., 2012). NDVI values were manually inspected when annual composites consisted of a large amount of pixels from images at the tail ends of the phenology window to ensure seasonality was not influencing results (with low NDVI values from leaf-off season).

Medium spatial resolution Landsat data is limited to analysis only as small as $30 \mathrm{~m}$ forest patches. In the Whitehorse area it is common for tree species to exist together in patches smaller than $30 \mathrm{~m}$ (Oswald, 1986). This is especially true at tree-line in sub-alpine environments where tree cover is sparse and interspersed with shrubs (Reese et al., 2002). Because individual trees and understory shrubs are undistinguishable, more field data and finer resolution imagery is required to investigate changes in species composition and vigour at more detailed spatial scales.

Inter- and intra-sensor calibration, and subtle changes in satellite orbit paths, have been known to cause spurious regional NDVI browning (Sulla-Menashe et al., 2016; Zhang et al., 2016). To address this, Landsat TM and ETM+ scenes were cross-calibrated to address subtle inter-sensor NDVI difference (Ju and Masek, 2016). Landsat 7 ETM+ was presumed not to have degraded throughout its short lifespan prior to SLC failure, and Landsat 5 TM was found to be sufficiently stable throughout its lifespan (Sulla-Menashe et al., 2016). Further validation of appropriate image selection, and inter and intra-sensor calibration, is evident in that no 
discernible regional browning trends were observed nor did landscape units respond differently over time.

It is important to ask which change detection algorithm is suitable for a study. Cohen et $a l$. , (2017) examined seven different change detection algorithms using multiple vegetation indices. Interestingly, all seven methods produced different results; however, stand replacing disturbances were much easier to detect than gradual changes in vegetation vigour. Assessing gradual change is very complex and results can be convoluted with spectral noise common in temporal trajectories. Furthermore, the largest challenge facing remote sensing studies investigating gradual change is the lack of available field data both spatially and temporally (Voglemann et al., 2016).

In the present study, several precautions were applied to avoid disturbance misrepresentation. Foremost, the most ubiquitous approach (NDVI linear trend analysis) in Subarctic and Arctic greening research was selected as the preferred method. Other Artic and Subarctic NDVI time-series have been validated with field measurements (D’Arrigo et al., 1987; D’Arrigo et al., 2004; Lloyd and Bunn, 2007; McGuire et al., 2010; Beck et al., 2011; Berner et al., 2011) and other satellite sensors (Myneni et al. 1997; Goetz et al., 2005; Bunn and Goetz, 2006; Verbyla, 2008; Parent and Vebyla, 2010; Beck and Goetz, 2011; Ju and Masek, 2016). Moreover, stand-replacing disturbances were excluded from analysis to avoid unwanted results, and to focus on gradual change. Government forest health maps were used to interrogate gradual disturbance, where possible. Nevertheless, using multiple vegetation indices and change detection algorithms, although rarely explored in artic and Subarctic regions, is an important approach for future vegetation studies (Ju and Masek, 2016). Although, beyond the scope of this 
study, findings contained herein provide a baseline with which to apply alternate change detection algorithms in Whitehorse, Yukon. 


\section{Chapter 4: Summary and Future Work}

Ecological responses to climate change are heterogeneous across regional scales (Ju and Masek, 2016). It is generally accepted that early-stage biome shifts specific to species physiological thresholds to temperature and precipitation are occurring (Walther et al., 2002). Also, that changes in local climate will have profound influence on both abiotic and biotic disturbance regimes (Price et al., 2013). This study contributes to an array of research investigating biome shifts within Arctic and Subarctic ecosystems (see Beck et al., 2011; Juday et al., 2015). Findings agree with other research that suggests treelines are moving upwards in altitude (Grace et al., 2002), and that local disturbance regimes are increasing associated with climate change (Hogg and Wein, 2005; Wagner and Doak, 2013; Yukon Energy, Mines and Resources, Forest Management Branch, 2014.

However, results of the present study indicate that greenness trends are still highly variable even when stratified by environmental variables at the landscape scale. Field observations and further investigation into the relative and combined influence of environmental variables is an important area of future research. Most interesting in this research was the strong greening response of white spruce over time and absence of a vegetation trend in trembling aspen. Given the prevailing browning trend of white spruce in Alaska (Barber et al., 2000; Baird et al., 2012), massive aspen die-back in the southern boreal forest (Michaelin et al., 2011), and that atmospheric moisture demand increases non-linearly with precipitation (Anderegg et al., 2013; Allen et al., 2015), it is important to continue to monitor vegetation as responses may vary as temperature and precipitation increase in Whitehorse, Yukon. Table 4.1 summarizes NDVI trends across landscape units from 1984 to 2009 in Whitehorse Yukon. 
Table 4.1: Summary of NDVI trends across investigated landscape units from 1984 to 2009 for Whitehorse, Yukon (significance, $\mathrm{p}<0.05$ ).

\begin{tabular}{|c|c|c|c|c|c|}
\hline & Landscape Unit & $\begin{array}{l}\text { Proportion of } \\
\text { Browning (\%) }\end{array}$ & $\begin{array}{l}\text { Proportion of } \\
\text { Greening }(\%)\end{array}$ & $\begin{array}{l}\text { Dominant } \\
\text { Trend }\end{array}$ & $\begin{array}{l}\text { Trend } \\
\text { Significance }\end{array}$ \\
\hline \multirow{9}{*}{$\stackrel{\mathbb{J}}{\dot{Z}}$} & Whitehorse Study Area & 1 & 37 & Greening & Significant \\
\hline & Lowlands & 2 & 30 & Greening & Significant \\
\hline & Uplands & 1 & 34 & Greening & Significant \\
\hline & Subalpine & 0 & 51 & Greening & Significant \\
\hline & North-facing & 1 & 46 & Greening & Significant \\
\hline & South-facing & 2 & 22 & Greening & Insignificant \\
\hline & No-aspect & 1 & 38 & Greening & Significant \\
\hline & 1958 Burn & 1 & 45 & Greening & Significant \\
\hline & 1991 Burn & 0 & 18 & Greening & Insignificant \\
\hline \multirow{10}{*}{ 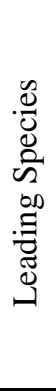 } & Deciduous & 4 & 24 & Greening & Insignificant \\
\hline & Balsam Poplar & 0 & 70 & Greening & Significant \\
\hline & Birch & 0 & 56 & Greening & Significant \\
\hline & Trembling Aspen & 4 & 21 & Greening & Insignificant \\
\hline & Lodgepole Pine & 1 & 33 & Greening & Significant \\
\hline & Subalpine Fir & 0 & 48 & Greening & Significant \\
\hline & White Spruce & 1 & 42 & Greening & Significant \\
\hline & Lowland White Spruce & 2 & 31 & Greening & Insignificant \\
\hline & Upland White Spruce & 1 & 41 & Greening & Significant \\
\hline & Subalpine White Spruce & 0 & 54 & Greening & Significant \\
\hline \multirow{11}{*}{ 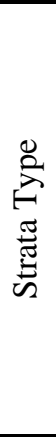 } & Deciduous & 5 & 16 & Greening & Insignificant \\
\hline & Deciduous Pine & 3 & 31 & Greening & Insignificant \\
\hline & Deciduous Spruce & 3 & 24 & Greening & Insignificant \\
\hline & Fir & 0 & 33 & Greening & Significant \\
\hline & Fir Mix & 0 & 51 & Greening & Significant \\
\hline & Pine & 1 & 35 & Greening & Significant \\
\hline & Pine Deciduous & 1 & 35 & Greening & Significant \\
\hline & Pine Spruce & 1 & 31 & Greening & Significant \\
\hline & Spruce & 1 & 48 & Greening & Significant \\
\hline & Spruce Deciduous & 2 & 27 & Greening & Insignificant \\
\hline & Spruce Pine & 1 & 38 & Greening & Significant \\
\hline \multirow{11}{*}{ 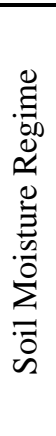 } & Dry & 2 & 20 & Greening & Insignificant \\
\hline & Moderately Dry & 1 & 32 & Greening & Significant \\
\hline & Moderately Fresh & 1 & 39 & Greening & Significant \\
\hline & Fresh & 1 & 38 & Greening & Significant \\
\hline & Very Fresh & 1 & 41 & Greening & Significant \\
\hline & Moderately Moist & 0 & 40 & Greening & Significant \\
\hline & Moist & 1 & 50 & Greening & Significant \\
\hline & Very Moist & 1 & 60 & Greening & Significant \\
\hline & Moderately Wet & 1 & 55 & Greening & Significant \\
\hline & Wet & 1 & 42 & Greening & Significant \\
\hline & Very Wet & 0 & 43 & Greening & Significant \\
\hline
\end{tabular}

With reference to the research questions posed at the outset of this study, the following conclusions can be drawn from the analyses contained herein: 


\section{Does a significant vegetation browning or greening trend exist in Whitehorse, Yukon?}

An overall greening trend was present in Whitehorse, Yukon from 1984 to 2009. Results were consistent with regional scale research into vegetation greenness trends using Landsat data (see Ju and Masek, 2016). Likewise, results are also comparable to parallel studies that show widespread greening trends in Subarctic and artic regions using field data (D'Arrigo et al., 2004; Berner et al., 2011; Griesbauer and Green, 2012), climate measurements (Hall et al., 1975; Keeling et al., 1996; Myneni et al., 1997) and other satellite-derived data sets (Goetz et al., 2005; Bunn and Goetz, 2006; Alcaraz-Segura et al., 2010; Beck et al., 2011; Price et al., 2013; Guay et al., 2014; Wylie et al., 2014).

\section{Can browning or greening trends be attributed to different vegetation classes, landscape positions, or topographic classes?}

Notwithstanding prevalent greening trends throughout the study area, several landscape classes displayed more pronounced and nuanced trends. The most intriguing result was the prominent greening trend of white spruce in Whitehorse. This finding is contrary to browning trends of white spruce in Alaska and other parts of Yukon (Barber et al., 2000; Beck et al., 2011; Baird et al., 2012). Additionally, subalpine white spruce at the tundra treeline ecotone displayed even more greening than other white spruce classes suggesting the presence of an early-stage biome shift (Beck et al., 2011). Furthermore, sites with characteristics favoured by white spruce; north-facing slopes and moist to moderately wet soil moisture regimes had more greening than other areas in aspect and soil moisture classes. Subalpine fir forests also had pronounced greening relative to other landscape units as expected per latitudinal and altitudinal upwards movement of treeline at ecotone edges (Grace et al., 2002; Wookey et al., 2009). It is postulated that increase in shrub density and productivity strongly influenced increasing subalpine NDVI too (Jia et al., 2009; Myers-Smith, et al 2011). 


\section{What are the major drivers impacting brownness and greenness on a landscape scale?}

Climate was the principal driver of greenness changes in Whitehorse, Yukon from 1984 to 2009. Variability in the magnitude of study area NDVI values corresponded to drought years and years of increased precipitation. Comparable results were found across leading species and management strata. Findings concur with studies at the forest stand scale that suggest boreal vegetation response to climate influences is species dependent and highly site specific (D'Arrigo et al., 2000; Kharuk et al., 2013; Danby and Hik, 2007; Miyamoto et al., 2010; Griesbauer and Green, 2012; Juday et al., 2015). Subtle increases in precipitation and temperature can benefit vegetation at one site while being detrimental at another because said benefits may be offset by evapotranspiration demand (Price et al., 2013), or plants may not be able to access water due to shallow rooting zones and soil characteristics (Verbyla, 2015). Balsam poplar and birch species gained from increased temperature and precipitation. Consistent with occupation of dry areas (Hogg and Hurdle, 1995; Hogg and Wein 2005), and a widespread aspen serpentine leaf miner outbreak throughout the time-series (Yukon Energy, Mines and Resources, Forest Management Branch, 2009; Wagner and Doak 2013), no greening trends were significant in any classes with strong trembling aspen components.

Dynamic changes are occurring in Canadian and Alaskan boreal forests. Southwestern Yukon and Whitehorse is one of the most populous areas in Canada's Arctic and Subarctic that will experience these changes, first hand. Accordingly, research into the impacts of climate change on surrounding forests should continue to inform adaptation strategies. More research to determine the impact of greening and more frequent disturbances on the forest resource sector in Yukon is needed on how forest management practices and harvesting can adapt to forest greening. Another area of future research is how greening trends are impacting traditional forest 
use. Yukon First Nations use the forest in all aspects of life; forests provide fuel, food, medicine, spirituality and cultural well-being (Yukon Energy, Mines and Resources, Forest Management Branch, 2018). From a remote sensing perspective, the logical next steps would be to confirm observations across different change detection techniques and vegetation indices. Future work should investigate more robust statistical methods such as non-parametric methods or methods more resistant to outliers such as Theil-Sen regression (Fernandes \& Leblanc, 2005) as a replacement for pixel-wise linear regression. While NDVI has displayed insensitivity in areas of high or low biomass (Baret and Guyot, 1991), affirmation of trends by less sensitive indices such as the enhanced vegetation index (Huete et al., 2002), tasseled cap transformation (Kauth, 1976) or disturbance index (Healy et al., 2005) is warranted. Another useful approach would be to look for disturbances within a time-series by deriving a piece-wise trend (see Kennedy et al., 2010). Better understanding of landscape unit influences on boreal greenness trends might be gained if the relative influence of different site characteristics were examined by statistical methods using multiple predictor variables. Some suggested statistical methods are multivariate analyses, principle components analysis or machine learning decision trees such as random forest (James et al., 2013).

There are opportunities to expand the time series used in this work, both spatially and temporally. Inclusion of Landsat 8 OLI images from 2013 to the present might provide further insights into forest change, particularly the recent effects of the aspen serpentine leaf miner decline. A recent applicable approach to address NDVI continuity between Landsat 7 ETM+ and Landsat 8 OLI that might be useful is suggested by Roy et al. (2016). Moreover, it would be interesting to extend the time series spatially to include all southwest Yukon and parts of Alaska. This would include a larger climate gradient ranging from the wet Pacific Coast to the sub arid 
interior Yukon, giving insight to how a wider range of precipitation and temperature affect landscape classes. Additionally, field data such as tree ring analysis or vegetation plots over time may be able to validate NDVI trends in Whitehorse. Finally, access to field data is invaluable to validating broad extent trends observed in satellite imagery (Kaufmann et al., 2008; Beck et al., 2011, Berner et al., 2011). 


\section{Appendices}

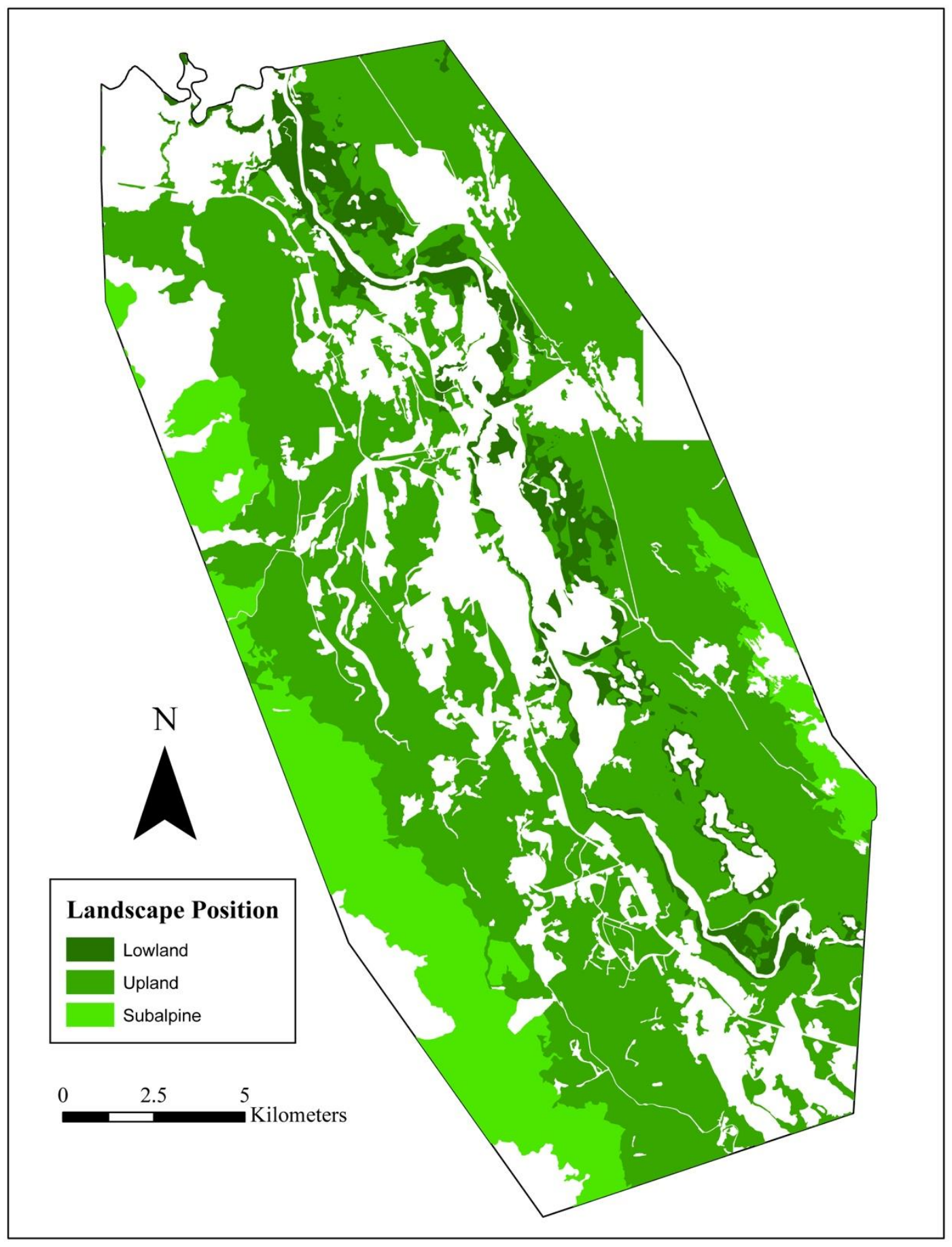

Appendix 1: Landscape position classes for Whitehorse, Yukon. 


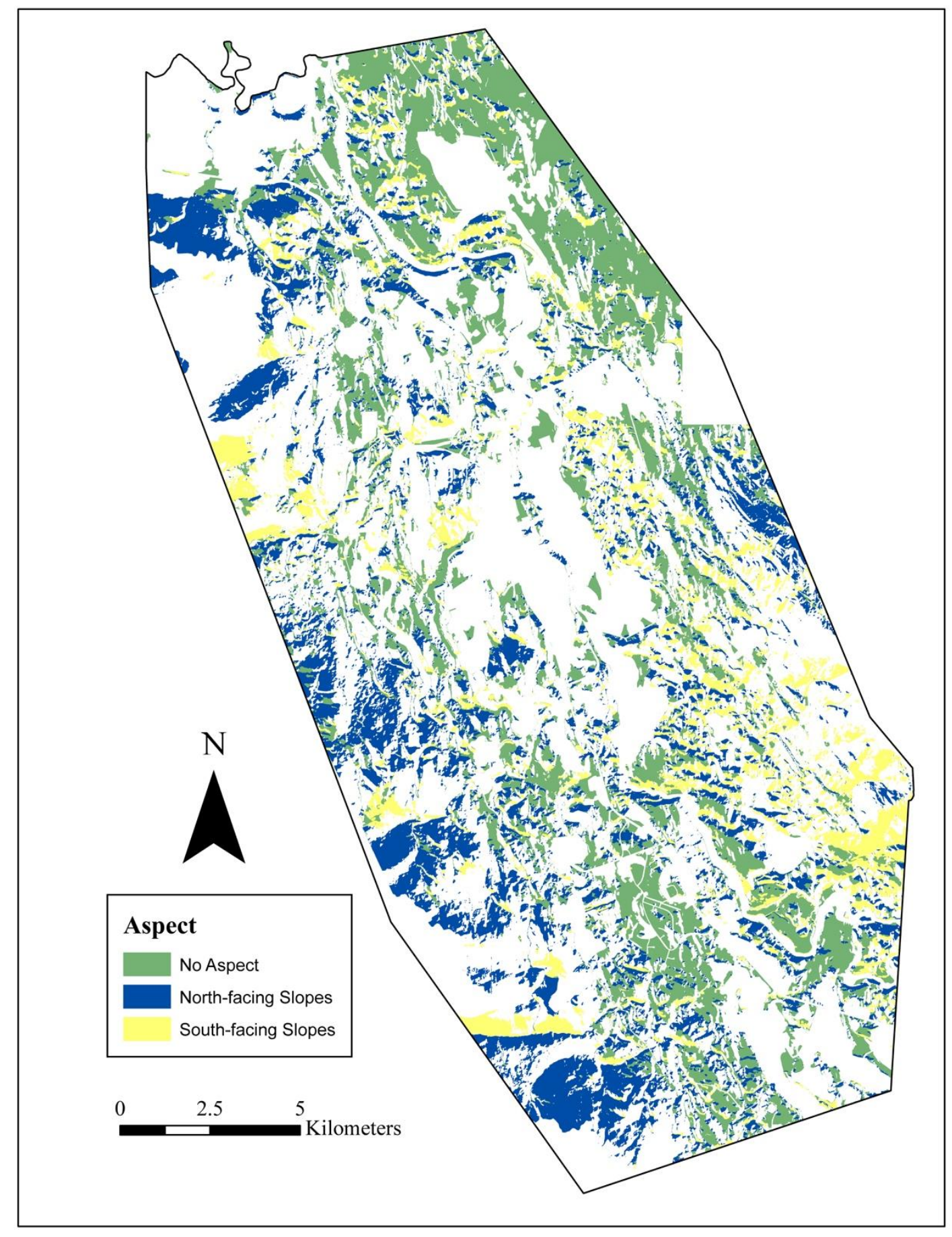

Appendix 2: Aspect classes for Whitehorse, Yukon. 


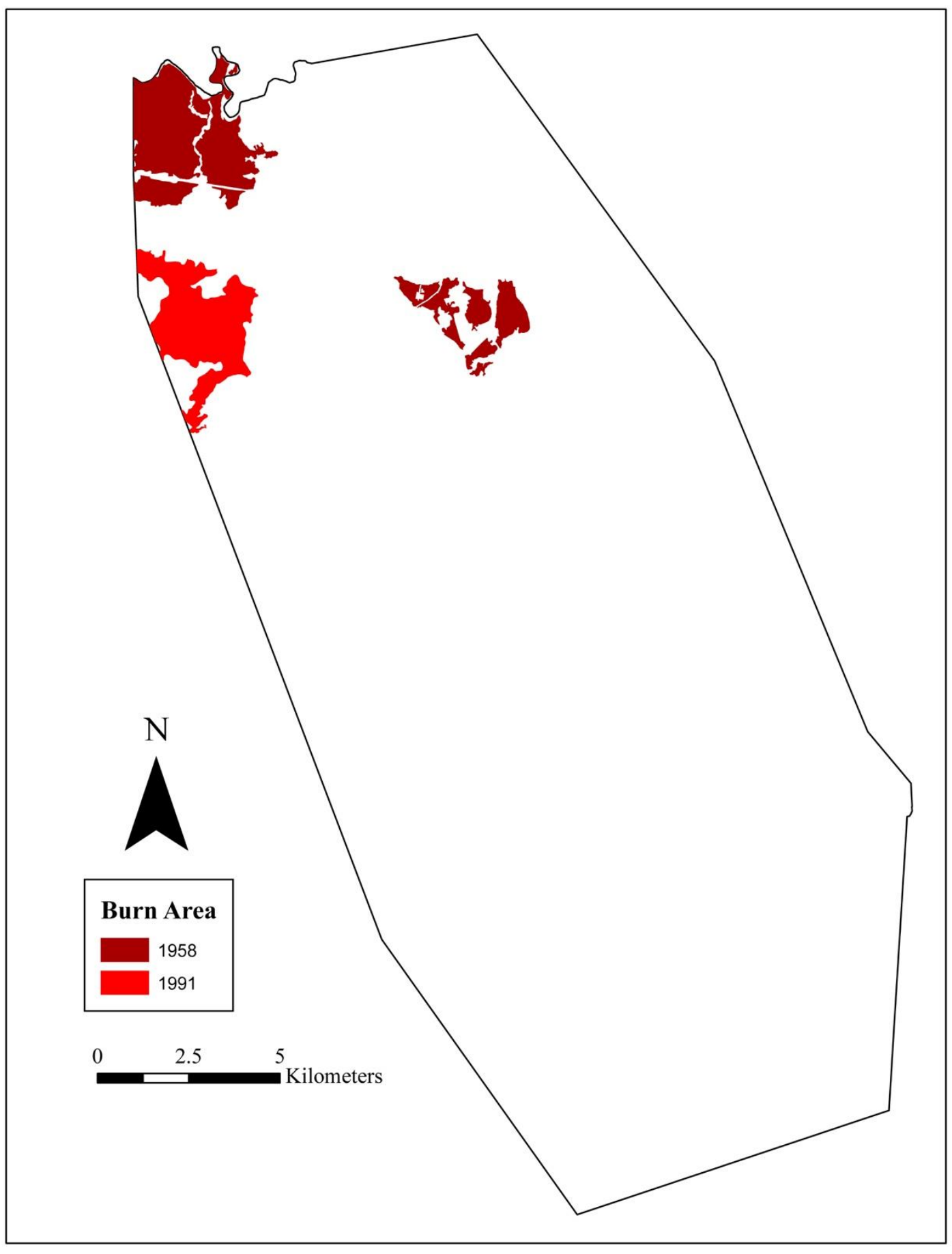

Appendix 3: Burn area classes for Whitehorse, Yukon. 


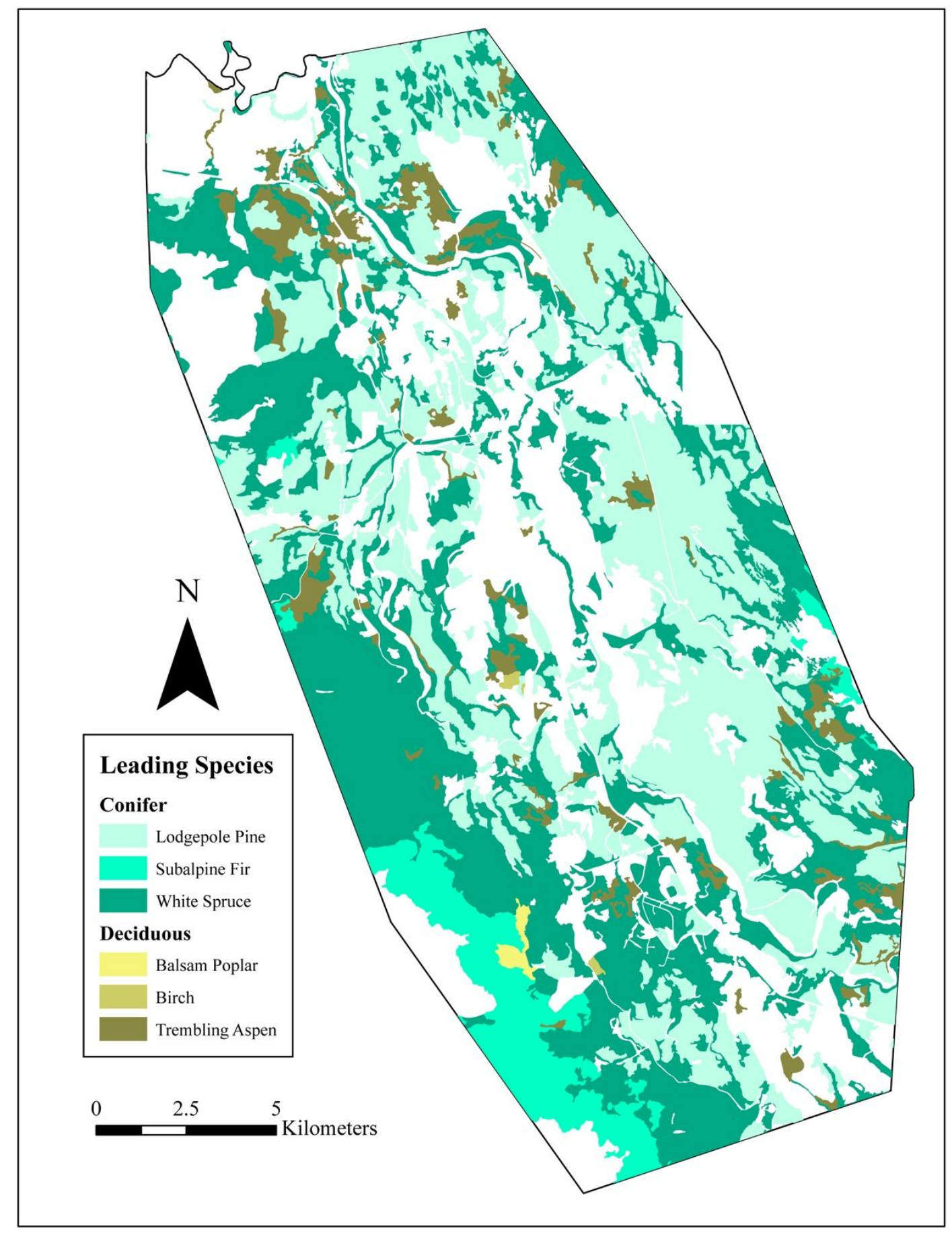

Appendix 4: Leading species classes for Whitehorse, Yukon. 


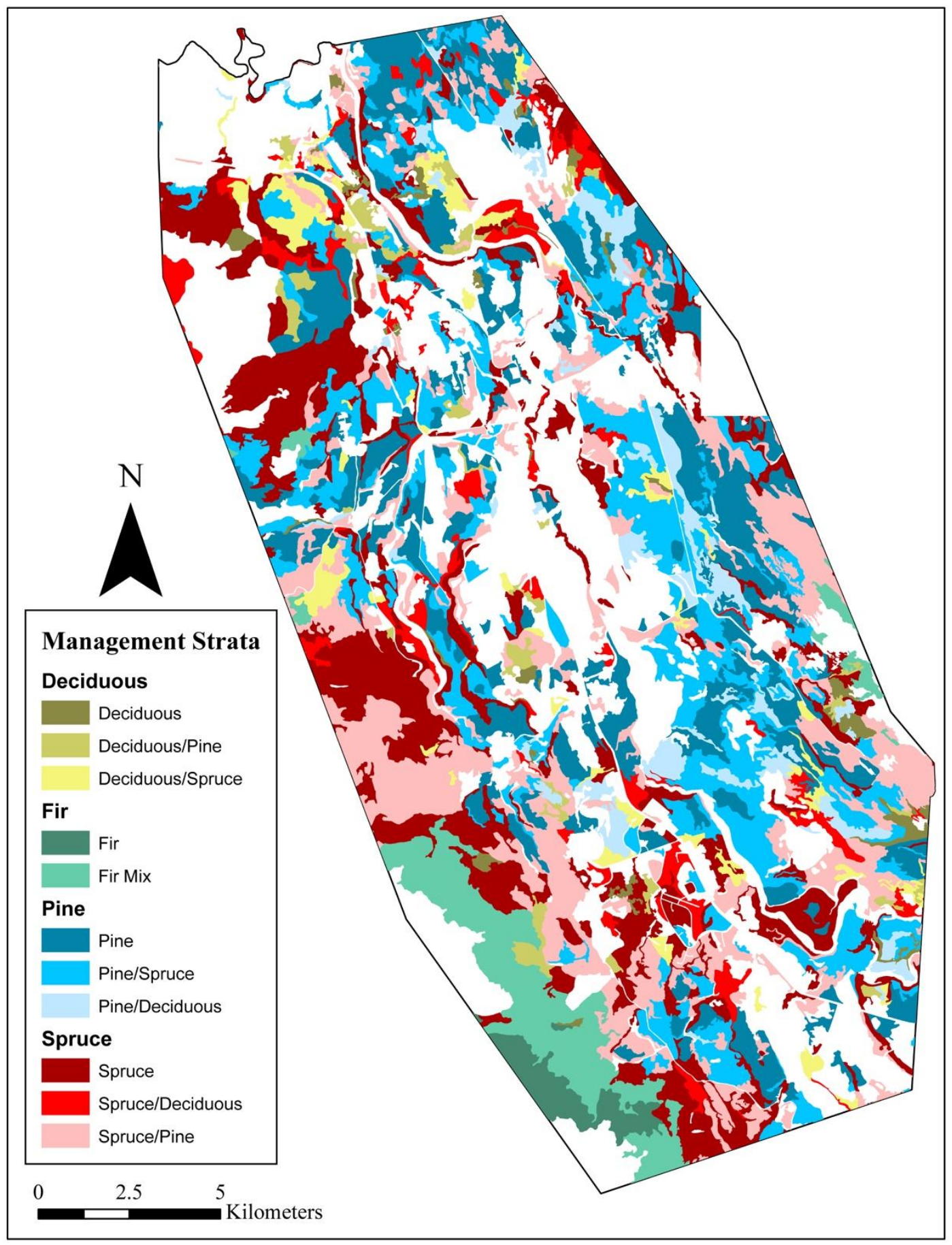

Appendix 5: Management strata for Whitehorse, Yukon. 


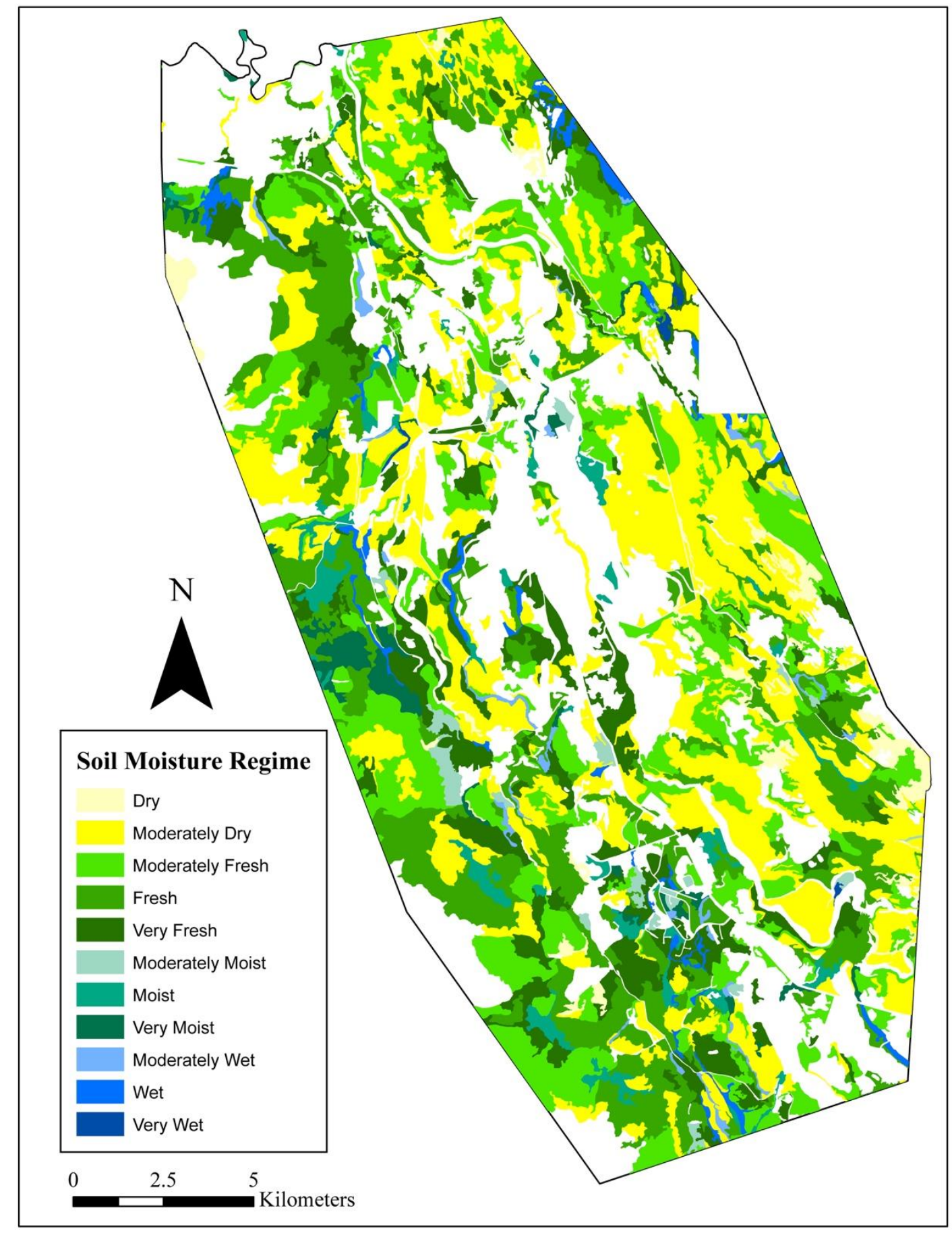

Appendix 6: Soil moisture classes for Whitehorse, Yukon. 
Appendix 7: Landsat scenes used for greenest annual composites.

\begin{tabular}{|c|c|c|c|c|c|}
\hline Year & Input Scenes & Year & Input Scenes & Year & Input Scenes \\
\hline 1984 & $\begin{array}{l}\text { LANDSAT/LT5_SR/LT50580181984173 } \\
\text { LANDSAT/LT5_SR/LT50580181984189 } \\
\text { LANDSAT/LT5_SR/LT50580181984205 } \\
\text { LANDSAT/LT5_SR/LT50580181984221 } \\
\text { LANDSAT/LT5_SR/LT50590181984196 }\end{array}$ & 1985 & $\begin{array}{l}\text { LANDSAT/LT5_SR/LT50580181984173 } \\
\text { LANDSAT/LT5_SR/LT50580181984189 } \\
\text { LANDSAT/LT5_SR/LT50580181984205 } \\
\text { LANDSAT/LT5_SR/LT50580181984221 } \\
\text { LANDSAT/LT5_SR/LT50590181984196 }\end{array}$ & 1986 & $\begin{array}{l}\text { LANDSAT/LT5_SR/LT50580181986178 } \\
\text { LANDSAT/LT5_SR/LT50580181986194 } \\
\text { LANDSAT/LT5_SR/LT50580181986210 } \\
\text { LANDSAT/LT5_SR/LT50580181986226 } \\
\text { LANDSAT/LT5_SR/LT50580181986242 } \\
\text { LANDSAT/LT5_SR/LT50590181986185 } \\
\text { LANDSAT/LT5_SR/LT50590181986201 } \\
\text { LANDSAT/LT5_SR/LT50590181986217 } \\
\text { LANDSAT/LT5_SR/LT50590181986233 }\end{array}$ \\
\hline 1987 & $\begin{array}{l}\text { LANDSAT/LT5_SR/LT50580181987181 } \\
\text { LANDSAT/LT5_SR/LT50590181987172 } \\
\text { LANDSAT/LT5_SR/LT50590181987188 } \\
\text { LANDSAT/LT5_SR/LT50590181987236 }\end{array}$ & 1991 & $\begin{array}{l}\text { LANDSAT/LT5_SR/LT50580181991176 } \\
\text { LANDSAT/LT5_SR/LT50590181991215 }\end{array}$ & 1994 & $\begin{array}{l}\text { LANDSAT/LT5_SR/LT50580181994200 } \\
\text { LANDSAT/LT5_SR/LT50580181994216 } \\
\text { LANDSAT/LT5_SR/LT50590181994191 } \\
\text { LANDSAT/LT5_SR/LT50590181994207 } \\
\text { LANDSAT/LT5_SR/LT50590181994223 } \\
\text { LANDSAT/LT5_SR/LT50590181994239 }\end{array}$ \\
\hline 1995 & $\begin{array}{l}\text { LANDSAT/LT5_SR/LT50580181995171 } \\
\text { LANDSAT/LT5_SR/LT50580181995187 } \\
\text { LANDSAT/LT5_SR/LT50580181995219 } \\
\text { LANDSAT/LT5_SR/LT50580181995235 } \\
\text { LANDSAT/LT5_SR/LT50590181995178 } \\
\text { LANDSAT/LT5_SR/LT50590181995194 } \\
\text { LANDSAT/LT5_SR/LT50590181995226 } \\
\text { LANDSAT/LT5_SR/LT50590181995242 }\end{array}$ & 1996 & $\begin{array}{l}\text { LANDSAT/LT5_SR/LT50580181996174 } \\
\text { LANDSAT/LT5_SR/LT50580181996190 } \\
\text { LANDSAT/LT5_SR/LT50580181996206 } \\
\text { LANDSAT/LT5_SR/LT50580181996238 } \\
\text { LANDSAT/LT5_SR/LT50590181996181 } \\
\text { LANDSAT/LT5_SR/LT50590181996229 }\end{array}$ & 1997 & $\begin{array}{l}\text { LANDSAT/LT5_SR/LT50580181997176 } \\
\text { LANDSAT/LT5_SR/LT50580181997192 } \\
\text { LANDSAT/LT5_SR/LT50580181997208 } \\
\text { LANDSAT/LT5_SR/LT50580181997240 } \\
\text { LANDSAT/LT5_SR/LT50590181997183 } \\
\text { LANDSAT/LT5_SR/LT50590181997199 } \\
\text { LANDSAT/LT5_SR/LT50590181997215 }\end{array}$ \\
\hline 1998 & $\begin{array}{l}\text { LANDSAT/LT5_SR/LT50580181998179 } \\
\text { LANDSAT/LT5_SR/LT50580181998195 } \\
\text { LANDSAT/LT5_SR/LT50580181998227 } \\
\text { LANDSAT/LT5_SR/LT50590181998186 } \\
\text { LANDSAT/LT5_SR/LT50590181998218 }\end{array}$ & 1999 & $\begin{array}{l}\text { LANDSAT/LT5_SR/LT50580181999182 } \\
\text { LANDSAT/LT5_SR/LT50580181999198 } \\
\text { LANDSAT/LT5_SR/LT50580181999214 } \\
\text { LANDSAT/LT5_SR/LT50580181999230 } \\
\text { LANDSAT/LT5_SR/LT50590181999189 } \\
\text { LANDSAT/LT5_SR/LT50590181999221 }\end{array}$ & 2000 & $\begin{array}{l}\text { LANDSAT/LE7_SR/LE70580182000177 } \\
\text { LANDSAT/LE7_SR/LE70580182000209 } \\
\text { LANDSAT/LE7_SR/LE70580182000225 } \\
\text { LANDSAT/LE7_SR/LE70580182000241 } \\
\text { LANDSAT/LE7_SR/LE70590182000184 } \\
\text { LANDSAT/LE7_SR/LE70590182000200 } \\
\text { LANDSAT/LE7_SR/LE70590182000216 }\end{array}$ \\
\hline 2001 & $\begin{array}{l}\text { LANDSAT/LE7_SR/LE70580182000177 } \\
\text { LANDSAT/LE7_SR/LE70580182000209 } \\
\text { LANDSAT/LE7_SR/LE70580182000225 } \\
\text { LANDSAT/LE7_SR/LE70580182000241 } \\
\text { LANDSAT/LE7_SR/LE70590182000184 } \\
\text { LANDSAT/LE7_SR/LE70590182000200 } \\
\text { LANDSAT/LE7_SR/LE70590182000216 }\end{array}$ & 2003 & $\begin{array}{l}\text { LANDSAT/LT5_SR/LT50580182003193 } \\
\text { LANDSAT/LT5_SR/LT50580182003209 } \\
\text { LANDSAT/LT5_SR/LT50580182003225 } \\
\text { LANDSAT/LT5_SR/LT50580182003241 } \\
\text { LANDSAT/LT5_SR/LT50590182003200 }\end{array}$ & 2005 & $\begin{array}{l}\text { LANDSAT/LT5_SR/LT50580182005182 } \\
\text { LANDSAT/LT5_SR/LT50580182005214 } \\
\text { LANDSAT/LT5_SR/LT50590182005173 } \\
\text { LANDSAT/LT5_SR/LT50590182005189 } \\
\text { LANDSAT/LT5_SR/LT50590182005205 } \\
\text { LANDSAT/LT5_SR/LT50590182005221 }\end{array}$ \\
\hline 2007 & $\begin{array}{l}\text { LANDSAT/LT5_SR/LT50580182007172 } \\
\text { LANDSAT/LT5_SR/LT50580182007188 } \\
\text { LANDSAT/LT5_SR/LT50580182007204 } \\
\text { LANDSAT/LT5_SR/LT50580182007220 } \\
\text { LANDSAT/LT5_SR/LT50590182007195 } \\
\text { LANDSAT/LT5_SR/LT50590182007227 }\end{array}$ & 2009 & $\begin{array}{l}\text { LANDSAT/LT5_SR/LT50580182009177 } \\
\text { LANDSAT/LT5_SR/LT50580182009193 } \\
\text { LANDSAT/LT5_SR/LT50580182009209 } \\
\text { LANDSAT/LT5_SR/LT50590182009184 } \\
\text { LANDSAT/LT5_SR/LT50590182009216 }\end{array}$ & & \\
\hline
\end{tabular}



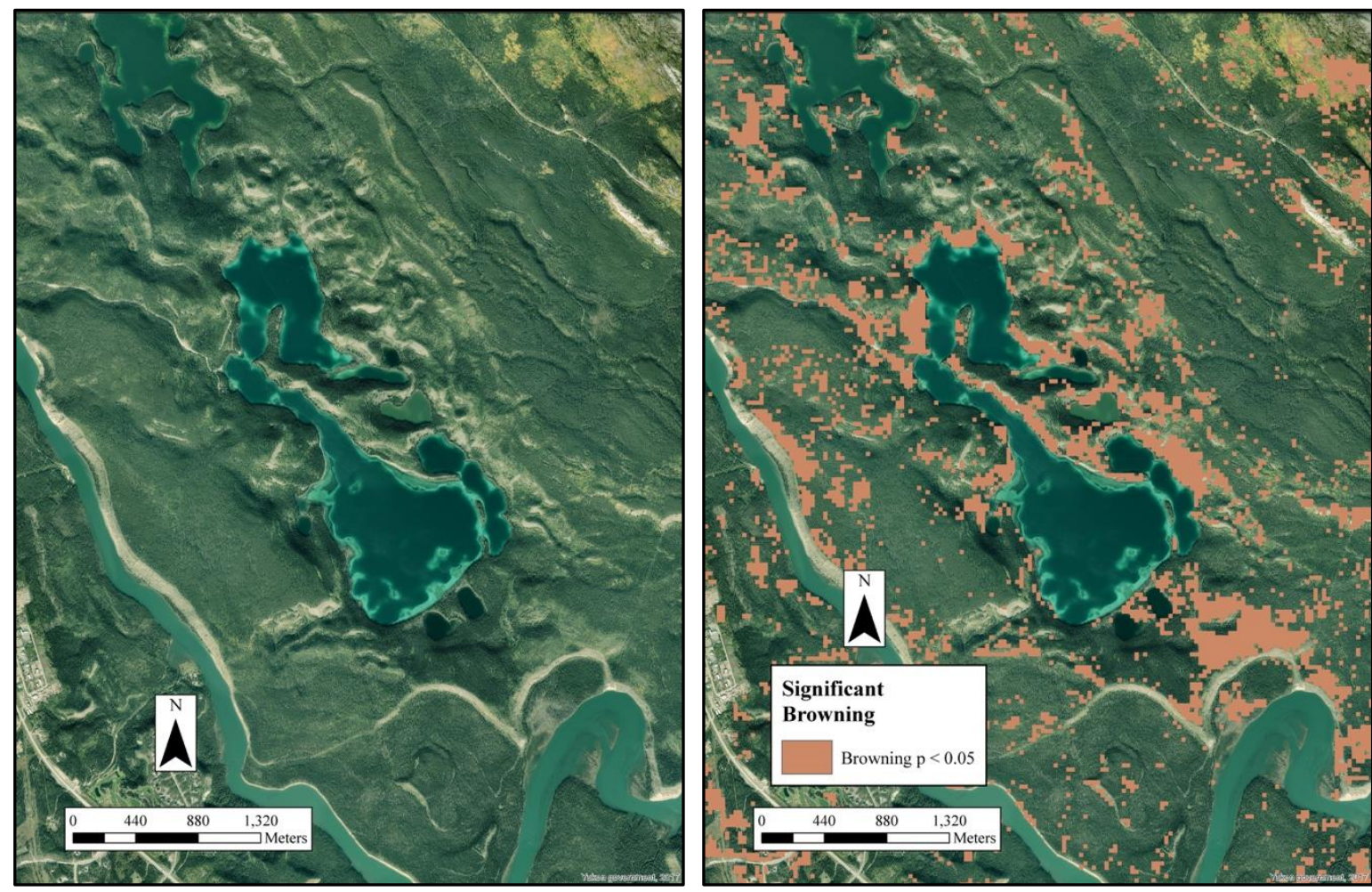

Appendix 8: NDVI browning on moderately dry south-facing ridges dominated by trembling aspen (left: 2009 air photo, right: 2009 air photo with significant browning pixels overlain). 


\section{References}

Alcaraz-Segura, D., Chuvieco, E., Epstein, H.E., Kasischke, E.S., Trishchenko, A., 2010. Debating the greening vs. browning of the North American boreal forest: Differences between satellite datasets. Glob. Chang. Biol. 16, 760-770. https://doi.org/10.1111/j.13652486.2009.01956.x

Allen, C.D., Macalady, A.K., Chenchouni, H., Bachelet, D., McDowell, N., Vennetier, M., Kitzberger, T., Rigling, A., Breshears, D.D., Hogg, E.H. (Ted), Gonzalez, P., Fensham, R., Zhang, Z., Castro, J., Demidova, N., Lim, J.H., Allard, G., Running, S.W., Semerci, A., Cobb, N., 2010. A global overview of drought and heat-induced tree mortality reveals emerging climate change risks for forests. For. Ecol. Manage. 259, 660-684. https://doi.org/10.1016/j.foreco.2009.09.001

Allen, C.D., Breshears, D.D., McDowell, N.G., 2015. On underestimation of global vulnerability to tree mortality and forest die-off from hotter drought in the Anthropocene. Ecosphere 6, art129. https://doi.org/10.1890/ES15-00203.1

Anderegg, W.R.L., Kane, J.M., Anderegg, L.D.L., 2013. Consequences of widespread tree mortality triggered by drought and temperature stress. Nat. Clim. Chang. 3, 30-36. https://doi.org/10.1038/nclimate1635

Anderegg, W.R.L., Hicke, J.A., Fisher, R.A., Allen, C.D., Aukema, J., Bentz, B., Hood, S., Lichstein, J.W., Macalady, A.K., Mcdowell, N., Pan, Y., Raffa, K., Sala, A., Shaw, J.D., Stephenson, N.L., Tague, C., Zeppel, M., 2015. Tree mortality from drought, insects, and their interactions in a changing climate. New Phytol. 208, 674-683. https://doi.org/10.1111/nph.13477

Baird, R. a., Verbyla, D., Hollingsworth, T.N., 2012. Browning of the landscape of interior Alaska based on 1986-2009 Landsat sensor NDVI. Can. J. For. Res. 42, 1371-1382. https://doi.org/10.1139/x2012-088

Banskota, A., Kayastha, N., Falkowski, M.J., Wulder, M.A., Froese, R.E., White, J.C., 2014. Forest Monitoring Using Landsat Time Series Data: A Review. Can. J. Remote Sens. 40, 362-384. https://doi.org/10.1080/07038992.2014.987376

Barber, V.A., Juday, G.P., Finney, B.P., 2000. Reduced growth of Alaskan white spruce in the twentieth century from temperature-induced drought stress. Nature 405, 668-673. https://doi.org/10.1038/35015049

Baret, F., Guyot, G., 1991. Potentials and limits of vegetation indices for LAI and APAR assessment. Remote Sens. Environ. 35, 161-173. https://doi.org/10.1016/00344257(91)90009-U

Bawden, F.C., 1933. Infrared photography and plant virus diseases. Nature, 132, 168. https:// $10.1038 / 132168 \mathrm{a} 0$ 
Beaubien, J., Jobin L., 1974. ERTS-1 imagery for broad mapping of forest damage and cover types of Anticosti Island. The Can. Surv., 28(2), 164-166.

Beaubien, J.,1986. Visual interpretation of vegetation through digitally enhanced LANDSATMSS images. Remote Sens. Rev., 2(1), 111-143.

Beck, P.S. a, Goetz, S.J., 2011. Satellite observations of high northern latitude vegetation productivity changes between 1982 and 2008: ecological variability and regional differences. Environ. Res. Lett. 6, 45501. https://doi.org/10.1088/1748-9326/7/2/029501

Beck, P.S.A., Juday, G.P., Alix, C., Barber, V.A., Winslow, S.E., Sousa, E.E., Heiser, P., Herriges, J.D., Goetz, S.J., 2011. Changes in forest productivity across Alaska consistent with biome shift. Ecol. Lett. 14, 373-379. https://doi.org/10.1111/j.14610248.2011.01598.x

Bentz, B.J., Régnière, J., Fettig, C.J., Hansen, M., Hayes, J.L., Hicke, J.A., Kelsey, R.G., Negrón, J.F., Seybold, S.J., 2010. Climate change and bark beetles of the western United States and Canada: Direct and indirect effects. Bioscience 60, 602-613. https://doi.org/10.1525/bio.2010.60.8.6

Berg, E.E., David Henry, J., Fastie, C.L., De Volder, A.D., Matsuoka, S.M., 2006. Spruce beetle outbreaks on the Kenai Peninsula, Alaska, and Kluane National Park and Reserve, Yukon Territory: Relationship to summer temperatures and regional differences in disturbance regimes. For. Ecol. Manage. 227, 219-232. https://doi.org/10.1016/j.foreco.2006.02.038

Berner, L.T., Beck, P.S.A., Bunn, A.G., Lloyd, A.H., Goetz, S.J., 2011. High-latitude tree growth and satellite vegetation indices: Correlations and trends in Russia and Canada (1982-2008). J. Geophys. Res. Biogeosciences 116, 1-14. https://doi.org/10.1029/2010JG001475

Birth, G.S., McVey, G., 1968. Measuring the color of growing turf with a reflectance radiometer. Agron. J., 60, 640-643.

Boisvenue, C., Running, S.W., 2006. Impacts of climate change on natural forest productivity Evidence since the middle of the 20th century. Glob. Chang. Biol. 12, 862-882. https://doi.org/10.1111/j.1365-2486.2006.01134.x

Bradley, B.A., Jacob, R.W., Hermance, J.F., Mustard, J.F., 2007. A curve fitting procedure to derive inter-annual phenologies from time series of noisy satellite NDVI data. Remote Sens. Environ. 106, 137-145. https://doi.org/10.1016/j.rse.2006.08.002

Breshears, D.D., Adams, H.D., Eamus, D., McDowell, N.G., Law, D.J., Will, R.E., Williams, A.P., Zou, C.B., 2013. The critical amplifying role of increasing atmospheric moisture demand on tree mortality and associated regional die-off. Front. Plant Sci. 4, 2-5. https://doi.org/10.3389/fpls.2013.00266 
Brown, R. J. E., 1976. Permafrost. Hydrological Atlas of Canada. Fisheries and Environment Canada. Ottawa.

Bunn, A.G., Goetz, S.J., 2006. Trends in satellite-observed circumpolar photosynthetic activity from 1982 to 2003: The influence of seasonality, cover type, and vegetation density. Earth Interact. 10. https://doi.org/10.1175/EI190.1

Bunn, A.G., Goetz, S.J., Kimball, J.S., Zhang, K., 2007. Northern High-Latitude Ecosystems Respond to Climate Change. Eos, Trans. Am. Geophys. Union 88, 333. https://doi.org/10.1029/2007EO340001

Burgan R.A. Hartford, J.C. Eldenshink, R.E., 1996. Using NDVI to assess departure from average greenness and it relation to fire business. Gen. Tech. Rep. INT-GTR-73, Ogden, UT; US Dept Agric. For. Serv. Intermt. Res. Station. 1-9.

Burn, C.R., 1998. The response (1958-1997) of permafrost and near-surface ground temperatures to forest fire, Takhini River valley, southern Yukon Territory. Can. J. Earth Sci. 35, 184199. https://doi.org/10.1139/e97-105

Campbell, J.B., 2007. Introduction to Remote Sensing. New York: Guilford.

Carroll, A. L., Taylor, S.W., Régnière, J., Safranyik, L., 2003. Effects of climate change on range expansion by the mountain pine beetle in British Columbia, in: Shore, T.S., Brooks, J.E., Stone J.E. (Eds.), Mountain Pine Beetle Symposium: Challenges and Solutions, Symposium held in Kelowna, British Columbia, Canada; 2003 October 30-31; Natural Resources Canada, Canadian Forest Service, Pacific Forestry Centre, Victoria, British Columbia. Information Report BC-X-399. 223-232.

Chance, C.M., Hermosilla, T., Coops, N.C., Wulder, M.A., White, J.C., 2016. Effect of topographic correction on forest change detection using spectral trend analysis of Landsat pixel-based composites. Int. J. Appl. Earth Obs. Geoinf. 44, 186-194. https://doi.org/10.1016/j.jag.2015.09.003

Chapin, F.S., Oswood, M.W., Van Cleve, K., Viereck, L.A., Verbyla, D.L. 2005. Alaska's Changing Boreal Forest. New York: Oxford University Press.

Chavardés, R.D., Daniels, L.D., Waeber, P.O., Innes, J.L., Nitschke, C.R., 2012. Did the 1976-77 switch in the Pacific Decadal Oscillation make white spruce in the southwest Yukon more susceptible to spruce bark beetle? For. Chron. 88, 513-518. https://doi.org/10.5558/tfc2012098

Chavardès, R.D., Daniels, L.D., Waeber, P.O., Innes, J.L., Nitschke, C.R., 2013. Unstable climate-growth relations for white spruce in southwest Yukon, Canada. Clim. Change 116, 593-611. https://doi.org/10.1007/s10584-012-0503-8 
Chen, J.M., Pavlic, G., Brown, L., Cihlar, J., Leblanc, S.G., White, H.P., Hall, R.J., Peddle, D.R., King, D.J., Trofymow, J.A., Swift, E., Van Der Sanden, J., Pellikka, P.K.E., 2002. Derivation and validation of Canada-wide coarse-resolution leaf area index maps using high-resolution satellite imagery and ground measurements. Remote Sens. Environ. 80, 165-184. https://doi.org/10.1016/S0034-4257(01)00300-5

Chen, L., Huang, J.G., Stadt, K.J., Comeau, P.G., Zhai, L., Dawson, A., Alam, S.A., 2017. Drought explains variation in the radial growth of white spruce in western Canada. Agric. For. Meteorol. 233, 133-142. https://doi.org/10.1016/j.agrformet.2016.11.012

City of Whitehorse. Planning Services Department 2014. Regional Parks Plan, prepared by J. Glynn-Morris General Consulting [Whitehorse, YT].

Clements, F.E., 1936. Nature and Structure of the Climax. J. Ecol. 24, 252. https://doi.org/10.2307/2256278

Cohen, W.B., Goward, S.N., 2004. Landsat's Role in Ecological Applications of Remote Sensing. Bioscience 54, 535-545. https://doi.org/DOI: 10.1641/00063568(2004)054[0535:LRIEAO]2.0.CO;2

Cohen, W.B., Yang, Z., Kennedy, R., 2010. Detecting trends in forest disturbance and recovery using yearly Landsat time series: 2. TimeSync - Tools for calibration and validation. Remote Sens. Environ. 114, 2911-2924. https://doi.org/10.1016/j.rse.2010.07.010

Cohen, W.B., Yang, Z., Stehman, S. V., Schroeder, T.A., Bell, D.M., Masek, J.G., Huang, C., Meigs, G.W., 2016. Forest disturbance across the conterminous United States from 19852012: The emerging dominance of forest decline. For. Ecol. Manage. 360, 242-252. https://doi.org/10.1016/j.foreco.2015.10.042

Cohen, W.B., Healey, S.P., Yang, Z., Stehman, S. V., Brewer, C.K., Brooks, E.B., Gorelick, N., Huang, C., Hughes, M.J., Kennedy, R.E., Loveland, T.R., Moisen, G.G., Schroeder, T.A., Vogelmann, J.E., Woodcock, C.E., Yang, L., Zhu, Z., 2017. How Similar Are Forest Disturbance Maps Derived from Different Landsat Time Series Algorithms? Forests 8, 119. https://doi.org/10.3390/f8040098

Colby, J.D., 1991. Topographic Normalization in Rugged Terrain. Photogramm. Eng. Remote Sensing 57, 531-537.

Colwell, R.N., 1956. Determining the prevelance of certain cereal crop diseases by means of aerial photography. Hilgardia, 26(5), 223-286.

Conway, A.J., 2012. An investigation of forest-grassland dynamics in Southwest Yukon, Canada. M.Sc. thesis, Department of Geography, Queen's University, Kingston, Ontario.

Conway, A.J., Danby, R.K., 2014. Recent advance of forest-grassland ecotones in southwestern Yukon. Can. J. For. Res. 44, 509-520. https://doi.org/10.1139/cjfr-2013-0429 
Coops, N.C., Waring, R.H., Wulder, M.A., White, J.C., 2009. Prediction and assessment of bark beetle-induced mortality of lodgepole pine using estimates of stand vigor derived from remotely sensed data. Remote Sens. Environ. 113, 1058-1066.

https://doi.org/10.1016/j.rse.2009.01.013

Coops, N.C., Wulder, M.A., 2010. Estimating the reduction in gross primary production due to mountain pine beetle infestation using satellite observations. Int. J. Remote Sens. 31, 21292138. https://doi.org/10.1080/01431160903474947

Coppin, P., Jonckheere, I., Nackaerts, K., Muys, B., Lambin, E., 2004. Review ArticleDigital change detection methods in ecosystem monitoring: a review. Int. J. Remote Sens. 25, 1565-1596. https://doi.org/10.1080/0143116031000101675

Crist, E.P., Cicone, R.C., 1984. A Physically-Based Transformation of Thematic Mapper DataThe TM Tasseled Cap. IEEE Trans. Geosci. Remote Sens. GE-22, 256-263. https://doi.org/10.1109/TGRS.1984.350619

Crist, E.P., Laurin, R., Cicone, R., 1986. Vegetation and soils information contained in transformed Thematic Mapper data. Proc. IGARSS' 86 Symp. D, 1465-1470.

Cwynar, L., MacDonald, G., 1987. Geographical Variation of Lodgepole Pine in Relation to Population History. Am. Soc. Nat. 129, 463-469.

D’Arrigo, R., Jacoby, G.C., Fung, I.Y., 1987. Boreal forests and atmosphere-biosphere exchange of carbon dioxide. Nature 329, 321-323. https://doi.org/10.1038/329321a0

D’Arrigo, R.D., Jacoby, G.C., Bunker, D.E., Malmstrom, C.M., Los, S.O., 2000. Correlation between maximum latewood density of annual tree rings and NDVI based estimates of forest productivity. Int. J. Remote Sens. 21, 2329-2336.

https://doi.org/10.1080/01431160050029611

D’Arrigo, R.D., Kaufmann, R.K., Davi, N., Jacoby, G.C., Laskowski, C., Myneni, R.B., Cherubini, P., 2004. Thresholds for warming-induced growth decline at elevational tree line in the Yukon Territory, Canada. Global Biogeochem. Cycles 18, 1-7. https://doi.org/10.1029/2004GB002249

Danby, R.K., Hik, D.S., 2007. Variability, contingency and rapid change in recent Subarctic alpine tree line dynamics. J. Ecol. 95, 352-363. https://doi.org/10.1111/j.13652745.2006.01200.x

Davies. D., C. E. Kennedy, McKenna K., 1983. Resource inventory- southern lakes. Land Planning Branch, Department of Renewable Resources, Government of Yukon. 
DeRose, R.J., Long, J.N., Ramsey, R.D., 2011. Combining dendrochronological data and the disturbance index to assess Engelmann spruce mortality caused by a spruce beetle outbreak in southern Utah, USA. Remote Sens. Environ. 115, 2342-2349. https://doi.org/10.1016/j.rse.2011.04.034

Dong, J., Kaufmann, R.K., Myneni, R.B., Tucker, C.J., Kauppi, P.E., Liski, J., Buermann, W., Alexeyev, V., Hughes, M.K., 2003. Remote sensing estimates of boreal and temperate forest woody biomass: carbon pools, sources, and sinks. Remote Sens. Environ. 393-410. https://doi.org/10.1016/S0034-4257(02)00130-X

Drobyshev, I., Gewehr, S., Berninger, F., Bergeron, Y., 2013. Species specific growth responses of black spruce and trembling aspen may enhance resilience of boreal forest to climate change. J. Ecol. 101, 231-242. https://doi.org/10.1111/1365-2745.12007

Eamus, D., Boulain, N., Cleverly, J., Breshears, D.D., 2013. Global change-type droughtinduced tree mortality: Vapor pressure deficit is more important than temperature per se in causing decline in tree health. Ecol. Evol. 3, 2711-2729. https://doi.org/10.1002/ece3.664

Eis, S., Craigdallie, D., Simmons, C., 1982. Growth of lodgepole pine and white spruce in the central interior of British Columbia. Can. J. For. Res. 12, 567-575. https://doi.org/10.1139/x82-088

Epstein, H.E., Raynolds, M.K., Walker, D.A., Bhatt, U.S., Tucker, C.J., Pinzon, J.E., 2012. Dynamics of aboveground phytomass of the circumpolar Arctic tundra during the past three decades. Environ. Res. Lett. 7. https://doi.org/10.1088/1748-9326/7/1/015506

Esau, I., Miles, V. V, Davy, R., Miles, M.W., Kurchatova, A., 2016. Trends in normalized difference vegetation index (NDVI) associated with urban development in northern West Siberia. Atmos. Chem. Phys. Discuss. 16, 1-29. https://doi.org/10.5194/acp-16-9563-2016

Fassnacht, K.S., Gower, S.T., MacKenzie, M.D., Nordheim, E. V, Lillesand, T.M., 1997. Estimating the leaf area index of North Central Wisconsin forests using the landsat thematic mapper. Remote Sens. Environ. 61, 229-245. https://doi.org/10.1016/S0034$\underline{4257(97) 00005-9}$

Fensholt, R., Sandholt, I., Stisen, S., Tucker, C., 2006. Analysing NDVI for the African continent using the geostationary meteosat second generation SEVIRI sensor. Remote Sens. Environ. 101, 212-229. https://doi.org/10.1016/j.rse.2005.11.013

Fernandes, R., Leblanc, S.G., 2005. Parametric (modified least squares) and non-parametric (Theil-Sen) linear regressions for predicting biophysical parameters in the presence of measurement errors. Remote Sens. Environ. https://doi.org/10.1016/j.rse.2005.01.005

Flannigan, M.D., Amiro, B.D., Logan, K.A., Stocks, B.J., Wotton, B.M., 2006. Forest Fires and Climate Change in the 21ST Century. Mitig. Adapt. Strateg. Glob. Chang. 11, 847-859. https://doi.org/10.1007/s11027-005-9020-7 
Forsythe, K.W., Wheate, R.D., 2003. Utilization of Landsat TM and Digital Elevation Data for the Delineation of Avalanche Slopes in Yoho National Park (Canada). IEEE Trans. Geosci. Remote Sens. 41, 2678-2682. https://doi.org/10.1109/TGRS.2003.817183

Francis S, Smith S, Janowicz J. 1999. Data integration and ecological zonation of Wolf Creek watershed. In Wolf Creek Research Basin - Hydrology, Ecology, Environment Proceedings of a workshop held in Whitehorse, Yukon, March 5-7, 1998. NHRI publication 37-121/ 1999E: Saskatoon, Saskatchewan; 93-100.

Franklin, S., Wulder, M., Skakun, R., Carroll, A., 2003. Mountain pine beetle red-attack forest damage classification using stratified Landsat TM data in British Columbia, Canada. Photogramm. Eng. Remote Sens. 69, 283-288. https://doi.org/10.14358/PERS.69.3.283

Fraser, R.H., Lantz, T.C., Olthof, I., Kokelj, S. V., Sims, R. a., 2014. Warming-Induced Shrub Expansion and Lichen Decline in the Western Canadian Arctic. Ecosystems 1151-1168. https://doi.org/10.1007/s10021-014-9783-3

Frazier, R.J., Coops, N.C., Wulder, M.A., 2015. Boreal Shield forest disturbance and recovery trends using Landsat time series. Remote Sens. Environ. 170, 317-327. https://doi.org/10.1016/j.rse.2015.09.015

Ganguly, S., Nemani, R.R., Zhang, G., Hashimoto, H., Milesi, C., Michaelis, A., Wang, W., Votava, P., Samanta, A., Melton, F., Dungan, J.L., Vermote, E., Gao, F., Knyazikhin, Y., Myneni, R.B., 2012. Generating global Leaf Area Index from Landsat: Algorithm formulation and demonstration. Remote Sens. Environ. 122, 185-202. https://doi.org/10.1016/j.rse.2011.10.032

Garbutt R. W., Hawkes B. C., Allen E. A., 2006. Spruce beetle and the forests of the southwest Yukon. Information Report BC-X-406. Natural Resources Canada, Victoria, BC.

Gauthier, S., Bernier, P., Burton, P.J., Edwards, J., Isaac, K., Isabel, N., Jayen, K., Goff, H. Le, Nelson, E. a, 2014. Climate change vulnerability and adaptation in the managed Canadian boreal forest. Environ. Rev. 30, 1-30.

Gimbarzevsky, P. 1984. Remote sensing in forest damage detection and appraisal--selected annotated bibliography. Information Report BC-X-253. Environment Canada, Canadian Forestry Service, Pacific Forest Research Centre, Victoria, BC.

Goetz, S.J., Bunn, A.G., Fiske, G.J., Houghton, R. a, 2005. Satellite-observed photosynthetic trends across boreal North America associated with climate and fire disturbance. Proc. Natl. Acad. Sci. U. S. A. 102, 13521-5. https://doi.org/10.1073/pnas.0506179102

Goetz, S.J., Fiske, G.J., Bunn, A.G., 2006. Using satellite time-series data sets to analyze fire disturbance and forest recovery across Canada. Remote Sens. Environ. 101, 352-365. https://doi.org/10.1016/j.rse.2006.01.011 
Goetz, S.J., Mack, M.C., Gurney, K.R., Randerson, J.T., Houghton, R.A., 2007. Ecosystem responses to recent climate change and fire disturbance at northern high latitudes: observations and model results contrasting northern Eurasia and North America. Environ. Res. Lett. 2, 45031. https://doi.org/10.1088/1748-9326/2/4/045031

Goodwin, N.R., Magnussen, S., Coops, N.C., Wulder, M. a., 2010. Curve fitting of time-series Landsat imagery for characterizing a mountain pine beetle infestation. Int. J. Remote Sens. 31, 3263-3271. https://doi.org/10.1080/01431160903186277

Gorelick, N., Hancher, M., Dixon, M., Ilyushchenko, S., Thau, D., Moore, R., 2016. Google Earth Engine: Planetary-scale geospatial analysis for everyone. Remote Sens. Environ. https://doi.org/10.1016/j.rse.2017.06.031

Goward, S., Arvldson, T., Williams, D., Faundeen, J., Irons, J., Franks, S., 2006. Historical record of landsat global coverage : Mission operations, NSLRSDA, and international cooperator stations. Photogramm. Eng. Remote Sensing 72, 1155-1169.

Grace, J., Berninger, F., Nagy, L., 2002. Impacts of climate change on the tree line. Ann. Bot. 90, 537-544. https://doi.org/10.1093/aob/mcf222

Green, D.S., 2005. Adaptive strategies in seedlings of three co-occurring, ecologically distinct northern coniferous tree species across an elevational gradient. Can. J. For. Res. 35, 910 917. https://doi.org/10.1139/x05-015

Green, D.S., 2007. Controls of growth phenology vary in seedlings of three, co-occurring ecologically distinct northern conifers. Tree Physiol. 27, 1197-1205. https://doi.org/10.1093/treephys/27.8.1197

Griesbauer, H.P., Green, D.S., 2012. Geographic and temporal patterns in white spruce climategrowth relationships in Yukon, Canada. For. Ecol. Manage. 267, 215-227. https://doi.org/10.1016/j.foreco.2011.12.004

Guay, K.C., Beck, P.S.A., Berner, L.T., Goetz, S.J., Baccini, A., Buermann, W., 2014. Vegetation productivity patterns at high northern latitudes: A multi-sensor satellite data assessment. Glob. Chang. Biol. 20, 3147-3158. https://doi.org/10.1111/gcb.12647

Gutsell, S.L., Johnson, E.A., 2002. Accurately ageing trees and examining their height-growth rates: Implications for interpreting forest dynamics. J. Ecol. 90, 153-166. https://doi.org/10.1046/j.0022-0477.2001.00646.x

Hais, M., Jonášová, M., Langhammer, J., Kučera, T., 2009. Comparison of two types of forest disturbance using multitemporal Landsat TM/ETM+ imagery and field vegetation data. Remote Sens. Environ. 113, 835-845. https://doi.org/10.1016/j.rse.2008.12.012 
Hale, S.R., Rock, B.N., 2003. Impact of Topographic Normalization on Land-Cover Classification Accuracy. Photogramm. Eng. Remote Sens. 69, 785-791. https://doi.org/10.14358/PERS.69.7.785

Hall, C.A.S., Ekdahl, C.A., Wartenberg, D.E., 1975. A fifteen-year record of biotic metabolism in the northern hemisphere. Nature 255, 136-138. https://doi.org/10.1038/255136a0

Hall, F.G., Strebel, D.E., Nickeson, J.E., Goetz, S.J., 1991. Radiometric rectification: Toward a common radiometric response among multidate, multisensor images. Remote Sens. Environ. 35, 11-27. https://doi.org/10.1016/0034-4257(91)90062-B

Hall, R.J., Castilla, G., White, J.C., Cooke, B.J., Skakun, R.S., 2016. Remote sensing of forest pest damage: a review and lessons learned from a Canadian perspective. 00, 1-61. https://doi.org/10.4039/tce.2016.11

Hart, S.J., Veblen, T.T., 2015. Detection of Spruce Beetle-induced Tree Mortality Using Highand Medium-resolution Remotely Sensed Imagery. Remote Sens. Environ. 168, 134-145. https://doi.org/10.1016/j.rse.2015.06.015

Healey, S.P., Cohen, W.B., Zhiqiang, Y., Krankina, O.N., 2005. Comparison of Tasseled Capbased Landsat data structures for use in forest disturbance detection. Remote Sens. Environ. 97, 301-310. https://doi.org/10.1016/j.rse.2005.05.009

Helmer, E.H., Ruzycki, T.S., Wunderle, J.M., Vogesser, S., Ruefenacht, B., Kwit, C., Brandeis, T.J., Ewert, D.N., 2010. Mapping tropical dry forest height, foliage height profiles and disturbance type and age with a time series of cloud-cleared Landsat and ALI image mosaics to characterize avian habitat. Remote Sens. Environ. 114, 2457-2473. https://doi.org/10.1016/j.rse.2010.05.021

Hennessey, R. \& Streicker, J., (2011). Whitehorse climate change adaptation plan. Northern Climate ExChange, Yukon Research Centre, Yukon College, Whitehorse, YT. 84 p.

Hermosilla, T., Wulder, M.A., White, J.C., Coops, N.C., Hobart, G.W., 2015. Regional detection, characterization, and attribution of annual forest change from 1984 to 2012 using Landsat-derived time-series metrics. Remote Sens. Environ. 170, 121-132. https://doi.org/10.1016/j.rse.2015.09.004

Hijmans R.J., Van Etten, J., 2012. Raster: Geographic analysis and modeling with raster data. R package version 2.0-12. http://CRAN.R-project.org/package=raster

Hogg, E.H., Bernier, P.Y., 2005. Climate change impacts on drought-prone forests in western Canada. For. Chron. 81, 675-682. https://doi.org/10.5558/tfc81675-5

Hogg, E.H., Brandt, J.P., Kochtubajda, B., 2002. Growth and dieback of aspen forests in northwestern Alberta, Canada, in relation to climate and insects. Can. J. For. Res. 32, 823832. https://doi.org/10.1139/x01-152 
Hogg, E.H., Hurdle, P.A., 1995. The aspen parkland in western Canada: A dry-climate analogue for the future boreal forest? Water. Air. Soil Pollut. 82, 391-400.

https://doi.org/10.1007/BF01182849

Hogg, E.H., Wein, R.W., 2005. Impacts of drought on forest growth and regeneration following fire in southwestern Yukon, Canada. Can. J. For. Res. 35, 2141-2150. https://doi.org/10.1139/x05-120

Holben, B., Justice, C., 1981. An examination of spectral band ratioing to reduce the topographic effect on remotely sensed data. Int. J. Remote Sens. 2, 115-133. https://doi.org/10.1080/01431168108948349

Huang, C., Goward, S.N., Masek, J.G., Thomas, N., Zhu, Z., Vogelmann, J.E., 2010. An automated approach for reconstructing recent forest disturbance history using dense Landsat time series stacks. Remote Sens. Environ. 114, 183-198. https://doi.org/10.1016/j.rse.2009.08.017

Huang, C., 2011. Forest change analysis using time-series Landsat observations. In Advances in Environmental Remote Sensing: Sensors, Algorithms, and Applications, ed Q. Weng, 348374, chapter 14. Boca Raton, FL: CRC Press.

Huete, A.R., 1988. A soil-adjusted vegetation index (SAVI). Remote Sens. Environ. 25, 295309. https://doi.org/10.1016/0034-4257(88)90106-X

Huete, A.R., 2012. Vegetation Indices, Remote Sensing and Forest Monitoring. Geogr. Compass 6, 513-532. https://doi.org/10.1111/j.1749-8198.2012.00507.x

Huete, A., Didan, K., Miura, T., Rodriguez, E.., Gao, X., Ferreira, L.., 2002. Overview of the radiometric and biophysical performance of the MODIS vegetation indices. Remote Sens. Environ. 83, 195-213. https://doi.org/10.1016/S0034-4257(02)00096-2

Huete, A. R., Liu, H., \& van Leeuwen, W. J. D., 1997. Use of vegetation indices in forested regions: Issues of linearity and saturation. In Anon (Ed.), International Geoscience and Remote Sensing Symposium (IGARSS). 4, 1966-1968. IEEE.

Huete, A., Miura, T., Yoshioka, H., Ratana, P., \& Broich, M., 2013. Indices of vegetation activity. In J. Hanes (Eds.), Biophysical applications of satellite remote sensing (1-41). Berlin: Springer.

Hughes, O. L., Campbell R. B., Muller J.E., Wheeler J.O., 1969. Glacial limits and flow patterns, Yukon Territory, south of 65 degrees north latitude. Department Energy, Mines and Resources., Geologic Survey of Canada.

Huemmrich, K.F., Privette, J.L., Mukelabai, M., Myneni, R.B., Knyazikhin, Y., 2005. Timeseries validation of MODIS land biophysical products in a Kalahari woodland, Africa. Int. J. Remote Sens. 26, 4381-4398. https://doi.org/10.1080/01431160500113393 
James, G., Witten, D., Tibshirani, R., Hastie, T., 2013. An Introduction to Statistical Learning with Applications in R. Book 431. https://doi.org/10.1007/978-1-4614-7138-7

Jeong, S.J., Ho, C.H., Gim, H.J., Brown, M.E., 2011. Phenology shifts at start vs. end of growing season in temperate vegetation over the Northern Hemisphere for the period 1982-2008. Glob. Chang. Biol. 17, 2385-2399. https://doi.org/10.1111/j.1365-2486.2011.02397.x

Jia, G.J., Epstein, H.E., Walker, D.A., 2003. Greening of Arctic Alaska, 1981-2001. Geophys. Res. Lett. 30, n/a-n/a. https://doi.org/10.1029/2003GL018268

Jia, G.J., Epstein, H.E., Walker, D.A., 2009. Vegetation greening in the canadian Arctic related to decadal warming. J. Environ. Monit. 11, 2231. https://doi.org/10.1039/b911677j

Johnstone, J.F., Chapin, F.S., 2003. Non-equilibrium succession dynamics indicate continued northern migration of lodgepole pine. Glob. Chang. Biol. 9, 1401-1409. https://doi.org/10.1046/j.1365-2486.2003.00661.x

Johnstone, J.F., McIntire, E.J.B., Pedersen, E.J., King, G., Pisaric, M.J.F., 2010. A sensitive slope: estimating landscape patterns of forest resilience in a changing climate. Ecosphere 1, art14. https://doi.org/10.1890/ES10-00102.1

Jones, H. G.,Vaughn, R. A., 2010. Remote Sensing of Vegetation Principles, Techniques and Applications. New York: Oxford University Press.

Ju, J., Masek, J.G., 2016. The vegetation greenness trend in Canada and US Alaska from 19842012 Landsat data. Remote Sens. Environ. 176, 1-16. https://doi.org/10.1016/j.rse.2016.01.001

Juday, G.P., Alix, C., Grant, T.A., 2015. Spatial coherence and change of opposite white spruce temperature sensitivities on floodplains in Alaska confirms early-stage boreal biome shift. For. Ecol. Manage. 350, 46-61. https://doi.org/10.1016/j.foreco.2015.04.016

Kasischke, E.S., Verbyla, D.L., Rupp, T.S., McGuire, a. D., Murphy, K. a., Jandt, R., Barnes, J.L., Hoy, E.E., Duffy, P. a., Calef, M., Turetsky, M.R., 2010. Alaska's changing fire regime - implications for the vulnerability of its boreal forests. Can. J. For. Res. 40, 13131324. https://doi.org/10.1139/X10-098

Kaufmann, R.K., D’Arrigo, R.D., Laskowski, C., Myneni, R.B., Zhou, L., Davi, N.K., 2004. The effect of growing season and summer greenness on northern forests. Geophys. Res. Lett. 31, 3-6. https://doi.org/10.1029/2004GL019608

Kaufmann, R.K., D’Arrigo, R.D., Paletta, L.F., Tian, H.Q., Jolly, W.M., Myneni, R.B., 2008. Identifying climatic controls on ring width: The timing of correlations between tree rings and NDVI. Earth Interact. 12, 1-14. https://doi.org/10.1175/2008EI263.1 
Kauth, R.J., Thomas, G.S., 1976. The tasselled cap - A graphic description of the spectraltemporal development of agricultural crops as seen by Landsat. Proc. Symp. Mach. Process. Remote. Sensed Data, West Lafayette, Indiana, U.S.A, 29 June-1 July 1976 41-51.

Keeling, C.D., Chin, J.F.S., Whorf, T.P., 1996. Increased activity of northern vegetation inferred from atmospheric $\mathrm{CO} 2$ measurements. Nature.

Keller, S.R., Soolanayakanahally, R.Y., Guy, R.D., Silim, S.N., Olson, M.S., Tiffin, P., 2011. Climate-driven local adaptation of ecophysiology and phenology in balsam poplar, Populus balsamifera L. (Salicaceae). Am. J. Bot. 98, 99-108. https://doi.org/10.3732/ajb.1000317

Kennedy, R.E., Andréfouët, S., Cohen, W.B., Gómez, C., Griffiths, P., Hais, M., Healey, S.P., Helmer, E.H., Hostert, P., Lyons, M.B., Meigs, G.W., Pflugmacher, D., Phinn, S.R., Powell, S.L., Scarth, P., Sen, S., Schroeder, T.A., Schneider, A., Sonnenschein, R., Vogelmann, J.E., Wulder, M.A., Zhu, Z., 2014. Bringing an ecological view of change to landsat-based remote sensing. Front. Ecol. Environ. 12, 339-346. https://doi.org/10.1890/130066

Kennedy, R.E., Cohen, W.B., Schroeder, T.A., 2007. Trajectory-based change detection for automated characterization of forest disturbance dynamics. Remote Sens. Environ. 110, 370-386. https://doi.org/10.1016/j.rse.2007.03.010

Kennedy, R.E., Yang, Z., Cohen, W.B., 2010. Detecting trends in forest disturbance and recovery using yearly Landsat time series: 1. LandTrendr - Temporal segmentation algorithms. Remote Sens. Environ. 114, 2897-2910.

https://doi.org/10.1016/j.rse.2010.07.008

Kerr, J.T., Ostrovsky, M., 2003. From space to species: Ecological applications for remote sensing. Trends Ecol. Evol. 18, 299-305. https://doi.org/10.1016/S0169-5347(03)00071-5

Kharuk, V.I., Ranson, K.J., Oskorbin, P.A., Im, S.T., Dvinskaya, M.L., 2013. Climate induced birch mortality in Trans-Baikal lake region, Siberia. For. Ecol. Manage. 289, 385-392. https://doi.org/10.1016/j.foreco.2012.10.024

Kramer, P., Kozlowski T., 1979. Physiology of Woody Plants, Academic, San Diego, Calif.

Kurz, W. a, Dymond, C.C., Stinson, G., Rampley, G.J., Neilson, E.T., Carroll, a L., Ebata, T., Safranyik, L., 2008. Mountain pine beetle and forest carbon feedback to climate change. Nature 452, 987-990. https://doi.org/10.1038/nature06777

Laidler, G.J., Treitz, P.M., Atkinson, D.M., 2008. Remote Sensing of Arctic Vegetation: Relations between the NDVI, Spatial Resolution and Vegetation Cover on Boothia Peninsula, Nunavut. Arctic 61, 1-13. 
Lantz, T.C., Kokelj, S. V., Gergel, S.E., Henry, G.H.R., 2009. Relative impacts of disturbance and temperature: persistent changes in microenvironment and vegetation in retrogressive thaw slumps. Glob. Chang. Biol. 15, 1664-1675. https://doi.org/10.1111/j.1365-

2486.2009.01917.x

Lee, Y. J., 1974. Monitoring forest management operations. Canadian Surveyor. 28(2), 135-141.

Lewkowicz, A.G., Ednie, M., 2004. Probability mapping of mountain permafrost using the BTS method, Wolf Creek, Yukon Territory, Canada. Permafr. Periglac. Process. 15, 67-80. https://doi.org/10.1002/ppp.480

Li, M., Zang, S., Zhang, B., Li, S., Wu, C., 2014. A review of remote sensing image classification techniques: The role of Spatio-contextual information. Eur. J. Remote Sens. 47, 389-411. https://doi.org/10.5721/EuJRS20144723

Lillesand, T., Kiefer, R. W., Chipman, J., 2015. Remote sensing and image interpretation Seventh Ed., John Wiley and Sons, Inc., New York.

Lloyd, A.H., Bunn, A.G., 2007. Responses of the circumpolar boreal forest to 20th century climate variability. Environ. Res. Lett. 2, 045013 (13pp). https://doi.org/10.1088/17489326/2/4/045013

Lloyd, A.H., Fastie, C.L., 2002. Spatial and temporal variability in the growth and climate respose of treeline trees in Alaska. Clim. Change 52, 481-502.

Loveland, T.R., Dwyer, J.L., 2012. Landsat: Building a strong future. Remote Sens. Environ. 122, 22-29. https://doi.org/10.1016/j.rse.2011.09.022

Lu, D., 2006. The potential and challenge of remote sensing-based biomass estimation. Int. J. Remote Sens. 27, 1297-1328. https://doi.org/10.1080/01431160500486732

Lu, D., Mausel, P., Brondízio, E., Moran, E., 2004. Change detection techniques. Int. J. Remote Sens. 25, 2365-2401. https://doi.org/10.1080/0143116031000139863

Malmström, C.M., Raffa, K.F., 2000. Biotic disturbance agents in the boreal forest: considerations for vegetation change models. Glob. Chang. Biol. 6, 35-48. https://doi.org/10.1046/j.1365-2486.2000.06012.x

Malmström, C.M., Thompson, M. V., Juday, G.P., Los, S.O., Randerson, J.T., Field, C.B., 1997. Interannual variation in global-scale net primary production: Testing model estimates. Global Biogeochem. Cycles 11, 367-392. https://doi.org/10.1029/97GB01419

Masek, J.G., Vermote, E.F., Saleous, N.E., Wolfe, R., Hall, F.G., Huemmrich, K.F., Gao, F., Kutler, J., Lim, T.K., 2006. A landsat surface reflectance dataset for North America, 19902000. IEEE Geosci. Remote Sens. Lett. 3, 68-72. https://doi.org/10.1109/LGRS.2005.857030 
Masek, J.G., Huang, C., Wolfe, R., Cohen, W., Hall, F., Kutler, J., Nelson, P., 2008. North American forest disturbance mapped from a decadal Landsat record. Remote Sens. Environ. 112, 2914-2926. https://doi.org/10.1016/j.rse.2008.02.010

McDonald, A.J., Gemmell, F.M., Lewis, P.E., 1998. Investigation of the Utility of Spectral Vegetation Indices for Determining Information on Coniferous Forests. Remote Sens. Environ. 66, 250-272. https://doi.org/10.1016/S0034-4257(98)00057-1

McGuire, a. D., Ruess, R.W., Lloyd, A., Yarie, J., Clein, J.S., Juday, G.P., 2010. Vulnerability of white spruce tree growth in interior Alaska in response to climate variability: dendrochronological, demographic, and experimental perspectives. This article is one of a selection of papers from The Dynamics of Change in Alaska's Boreal For. Can. J. For. Res. 40, 1197-1209. https://doi.org/10.1139/X09-206

McKenney, D.W., Pedlar, J.H., Lawrence, K., Campbell, K., Hutchinson, M.F., 2007. Potential Impacts of Climate Change on the Distribution of North American Trees. Bioscience 57, 939-948. https://doi.org/10.1641/B571106

Mckenney, D.W., Pedlar, J.H., Rood, R.B., Price, D., 2011. Revisiting projected shifts in the climate envelopes of North American trees using updated general circulation models. Glob. Chang. Biol. 17, 2720-2730. https://doi.org/10.1111/j.1365-2486.2011.02413.x

McManus, kelly M., Morton, D.C., Masek, J.G., Wang, D., Sexton, J.O., Nagol, J.R., Ropars, P., Boudreau, S., 2012. Satellite-based evidence for shrub and graminoid tundra expansion in northern Quebec from 1986 to 2010. Glob. Chang. Biol. 18, 2313-2323. https://doi.org/10.1111/j.1365-2486.2012.02708.x

Michaelian, M., Hogg, E.H., Hall, R.J., Arsenault, E., 2011. Massive mortality of aspen following severe drought along the southern edge of the Canadian boreal forest. Glob. Chang. Biol. 17, 2084-2094. https://doi.org/10.1111/j.1365-2486.2010.02357.x

Miles, V. V, Esau, I., 2016. Spatial heterogeneity of greening and browning between and within bioclimatic zones in northern West Siberia. Environ. Res. Lett. 11, 115002. https://doi.org/10.1088/1748-9326/11/11/115002

Millward, A.A., Kraft, C.E., 2004. Physical influences of landscape on a large-extent ecological disturbance: The northeastern North American ice storm of 1998. Landsc. Ecol. 19, 99-111. https://doi.org/10.1023/B:LAND.0000018369.41798.2f

Miyamoto, Y., Griesbauer, H.P., Scott Green, D., 2010. Growth responses of three coexisting conifer species to climate across wide geographic and climate ranges in Yukon and British Columbia. For. Ecol. Manage. 259, 514-523. https://doi.org/10.1016/j.foreco.2009.11.008 
Moore, W. C., 1974. Analysis of ERTS-1 imagery for wind damage to forests. In G.E. Thompson (Eds.), Proceedings of the Second Canadian Symposium on Remote Sensing. 1974, April 29-May 1. University of Guelph, Guelph, Ontario. Canadian Remote Sensing Society, 337-346.

Murtha, P. A., 1969. Aerial photographic interpretation of forest damage: An annotated bibliography. Information Report FMR-X-16. Forest Management Institute, Ottawa, Ontario, Forestry Branch Department of Fisheries and Forestry.

Murtha, P. A., 1974. A guide to air photo interpretation of forest damage in Canada. Publication No. 1292. Canadian Forest Service, Ottawa.

Myers-Smith, I.H., Forbes, B.C., Wilmking, M., Hallinger, M., Lantz, T., Blok, D., Tape, K.D., Macias-Fauria, M., Sass-Klaassen, U., Lévesque, E., Boudreau, S., Ropars, P., Hermanutz, L., Trant, A., Collier, L.S., Weijers, S., Rozema, J., Rayback, S.A., Schmidt, N.M., Schaepman-Strub, G., Wipf, S., Rixen, C., Ménard, C.B., Venn, S., Goetz, S., AndreuHayles, L., Elmendorf, S., Ravolainen, V., Welker, J., Grogan, P., Epstein, H.E., Hik, D.S., 2011. Shrub expansion in tundra ecosystems: dynamics, impacts and research priorities. Environ. Res. Lett. 6, 45509. https://doi.org/10.1088/1748-9326/6/4/045509

Myneni, R.B., Keeling, C.D., Tucker, C.J., Asrar, G., Nemani, R.R., 1997. Increased plant growth in the northern high latitudes from 1981 to 1991. Nature 386, 698-702. https://doi.org/10.1038/386698a0

Myren, D. T., 1994. Tree diseases of eastern Canada. Natural Resources Canada, Canadian Forest Service, Ottawa.

NASA, 2017. Measuring Vegetation? Retrieved from https://earthobservatory.nasa.gov/Features/MeasuringVegetation (accessed 11 November 2017)

Neigh, C..R., Tucker, C.J., Townshend, J.R.G., 2008. North American vegetation dynamics observed with multi-resolution satellite data. Remote Sens. Environ. 112, 1749-1772. https://doi.org/10.1016/j.rse.2007.08.018

Nemani, R.R., Running, S.W., 1989. Estimation of regional surface resistance to evapotranspiration from NDVI and thermal-IR AVHRR data. J. Appl. Meteorol. https://doi.org/10.1175/1520-0450(1989)028<0276:EORSRT>2.0.CO;2

Nemani, R.R., Keeling, C.D., Hashimoto, H., Jolly, W.M., Piper, S.C., Tucker, C.J., Myneni, R.B., Running, S.W., 2003. Climate-Driven Increases in Global Terrestrial Net Primary Production. Source Sci. New Ser. 300, 1560-1563. https://doi.org/10.1126/science.1082750

Nielsen, V., 1974. Photographic enhancement of ERTS-1 imagery. Can. Surv., 28(2), 178-179. 
NOAA, 2016. What is remote sensing? Retrieved from http://oceanservice.noaa.gov/facts/remotesensing.html (accessed 11 November 2017)

Ogden, A.E., Innes, J.L., 2008. Climate change adaptation and regional forest planning in southern Yukon, Canada. Mitig. Adapt. Strateg. Glob. Chang. 13, 833-861. https://doi.org/10.1007/s11027-008-9144-7

Olthof, I., Pouliot, D., Latifovic, R., Chen, W., 2008. Recent (1986-2006) vegetation-specific NDVI trends in northern Canada from satellite Data. Arctic 61, 381-394.

Olson, M.S., Levsen, N., Soolanayakanahally, R.Y., Guy, R.D., Schroeder, W.R., Keller, S.R., Tiffin, P., 2013. The adaptive potential of Populus balsamifera L. to phenology requirements in a warmer global climate. Mol. Ecol. 22, 1214-1230. https://doi.org/10.1111/mec.12067

Oswald, E.T., Brown, B.N., 1986. Forest communities in Lake Laberge Ecoregion, Yukon Territory. Canadian Forestry Service, Pacific Forestry Centre, Victoria, British Columbia.

Oswald, E.T. and B.N. Brown. 1990. Vegetation establishment during 5 years following wildfire in northern British Columbia and southern Yukon Territory. Information Report BC-X-320 Pacific and Yukon Region. Forestry Canada, Pacific Forestry Center, Victoria.

Parent, M.B., Verbyla, D., 2010. The browning of Alaska's boreal forest. Remote Sens. 2, 27292747. https://doi.org/10.3390/rs2122729

Pasquarella, V.J., Holden, C.E., Kaufman, L., Woodcock, C.E., 2016. From imagery to ecology: leveraging time series of all available Landsat observations to map and monitor ecosystem state and dynamics. Remote Sens. Ecol. Conserv. 1-19. https://doi.org/10.1002/rse2.24

Paudel, S.K., Waeber, P.O., Simard, S.W., Innes, J.L., Nitschke, C.R., 2016. Multiple factors influence plant richness and diversity in the cold and dry boreal forest of southwest Yukon, Canada. Plant Ecol. 217, 505-519. https://doi.org/10.1007/s11258-016-0595-8

Pecora, W. T., 1967. Surveying the Earth's resources from space. Surv. and Map., 27(4), 639643.

Peterson, D.W., Peterson, D.L., Ettl, G.J., 2002. Growth responses of subalpine fir to climatic variability in the Pacific Northwest. Can. J. For. Res. 32, 1503-1517. https://doi.org/10.1139/x02-072

Peterson, B. J., Mcclelland, J., Curry, R., Holmes, R. M., Walsh, J. E., \& Aagaard, K., 2006. Trajectory Shifts in the Arctic and Subarctic Freshwater Cycle. Science. 313, 1061-1066. https://doi.org/10.1126/science.1122593 
Pettorelli, N., Vik, J.O., Mysterud, A., Gaillard, J.M., Tucker, C.J., Stenseth, N.C., 2005. Using the satellite-derived NDVI to assess ecological responses to environmental change. Trends Ecol. Evol. 20, 503-510. https://doi.org/10.1016/j.tree.2005.05.011

Pettorelli, N., 2013. The Normalized Difference Vegetation Index. Oxford: Oxford University Press.

Pickell, P.D., Hermosilla, T., J. Frazier, R., Coops, N.C., Wulder, M.A., 2015. Forest recovery trends derived from Landsat time series for North American boreal forests. Int. J. Remote Sens. 37, 138-149. https://doi.org/10.1080/2150704X.2015.1126375

Potapov, P., Turubanova, S., Hansen, M.C., 2011. Regional-scale boreal forest cover and change mapping using Landsat data composites for European Russia. Remote Sens. Environ. 115, 548-561. https://doi.org/10.1016/j.rse.2010.10.001

Potter, C., 2014. GIScience \& Remote Sensing Regional analysis of MODIS satellite greenness trends for ecosystems of interior Alaska Regional analysis of MODIS satellite greenness trends for ecosystems of interior Alaska. GIScience Remote Sens. 51, 390-402. https://doi.org/10.1080/15481603.2014.933606

Price, D.T., Alfaro, R.I., Brown, K.J., Flannigan, M.D., Fleming, R.A., Hogg, E.H., Girardin, M.P., Lakusta, T., Johnston, M., McKenney, D.W., Pedlar, J.H., Stratton, T., Sturrock, R.N., Thompson, I.D., Trofymow, J.A., Venier, L.A., 2013. Anticipating the consequences of climate change for Canada's boreal forest ecosystems. Environ. Rev. 21, 322-365. https://doi.org/10.1139/er-2013-0042

La Puma, I.P., Philippi, T.E., Oberbauer, S.F., 2007. Relating NDVI to ecosystem CO2exchange patterns in response to season length and soil warming manipulations in arctic Alaska. Remote Sens. Environ. 109, 225-236. https://doi.org/10.1016/j.rse.2007.01.001

Rees, G., Brown, I., Mikkola, K., Virtanen, T., Werkman, B., 2002. How Can the Dynamics of the Tundra-Taiga Boundary Be Remotely Monitored? Ambio 56-62. https://doi.org/10.2307/25094576

R Core Team, 2015. R: A language and environment for statistical computing. R Foundation for Statistical Computing, Vienna, Austria. https://www.R-project.org/

Reich, P.B., Oleksyn, J., 2004. Global patterns of plant leaf N and P in relation to temperature and latitude. Proc. Natl. Acad. Sci. 101, 11001-11006. https://doi.org/10.1073/pnas.0403588101

Rouse, J.W., Haas, R.H., Schell, J.A., Deering, D.W., 1973. Monitoring Vegetation Systems in the Great Okains with ERTS. Third Earth Resour. Technol. Satell. Symp. 1, 325-333. 
Rowland, E.L., Fresco, N., Reid, D., Cooke, H.A., 2016. Examining climate-biome (“cliome”) shifts for Yukon and its protected areas. Glob. Ecol. Conserv. 8, 1-17. https://doi.org/10.1016/j.gecco.2016.07.006

Roy, D.P., Ju, J., Kline, K., Scaramuzza, P.L., Kovalskyy, V., Hansen, M., Loveland, T.R., Vermote, E., Zhang, C., 2010. Web-enabled Landsat Data (WELD): Landsat ETM+ composited mosaics of the conterminous United States. Remote Sens. Environ. 114, 35-49. https://doi.org/10.1016/j.rse.2009.08.011

Roy, D.P., Zhang, H.K., Ju, J., Gomez-Dans, J.L., Lewis, P.E., Schaaf, C.B., Sun, Q., Li, J., Huang, H., Kovalskyy, V., 2016. A general method to normalize Landsat reflectance data to nadir BRDF adjusted reflectance. Remote Sens. Environ. 176, 255-271. https://doi.org/10.1016/j.rse.2016.01.023

Safranyik, L., Carroll, A.L., Régnière, J., Langor, D.W., Riel, W.G., Shore, T.L., Peter, B., Cooke, B.J., Nealis, V.G., Taylor, S.W., 2010. Potential for range expansion of mountain pine beetle into the boreal forest of North America. Can. Entomol. 142, 415-442. https://doi.org/10.4039/n08-CPA01

Schott, J.R., Salvaggio, C., Volchok, W.J., 1988. Radiometric scene normalization using pseudoinvariant features. Remote Sens. Environ. 26. https://doi.org/10.1016/00344257(88)90116-2

Schroeder, T.A., Cohen, W.B., Song, C., Canty, M.J., Yang, Z., 2006. Radiometric correction of multi-temporal Landsat data for characterization of early successional forest patterns in western Oregon. Remote Sens. Environ. 103, 16-26. https://doi.org/10.1016/j.rse.2006.03.008

Schroeder, T.A., Wulder, M.A., Healey, S.P., Moisen, G.G., 2011. Mapping wildfire and clearcut harvest disturbances in boreal forests with Landsat time series data. Remote Sens. Environ. 115, 1421-1433. https://doi.org/10.1016/j.rse.2011.01.022

Schwartz, M.D., Ahas, R., Aasa, A., 2006. Onset of spring starting earlier across the Northern Hemisphere. Glob. Chang. Biol. 12, 343-351. https://doi.org/10.1111/j.13652486.2005.01097.x

Senf, C., Pflugmacher, D., Wulder, M.A., Hostert, P., 2015. Characterizing spectral-temporal patterns of defoliator and bark beetle disturbances using Landsat time series. Remote Sens. Environ. 170, 166-177. https://doi.org/10.1016/j.rse.2015.09.019

Sharik, T.L., Adair, W., Baker, F. a., Battaglia, M., Comfort, E.J., D’Amato, A.W., Delong, C., DeRose, R.J., Ducey, M.J., Harmon, M., Levy, L., Logan, J. a., O’Brien, J., Palik, B.J., Roberts, S.D., Rogers, P.C., Shinneman, D.J., Spies, T., Taylor, S.L., Woodall, C., Youngblood, A., 2010. Emerging Themes in the Ecology and Management of North American Forests. Int. J. For. Res. 2010, 1-11. https://doi.org/10.1155/2010/964260 
Slayback, D.A., Pinzon, J.E., Los, S.O., Tucker, C.J., 2003. Northern hemisphere photosynthetic trends 1982-99. Glob. Chang. Biol. 9, 1-15. https://doi.org/10.1046/j.1365-

2486.2003.00507.x

Smith, A.M.S., Kolden, C.A., Tinkham, W.T., Talhelm, A.F., Marshall, J.D., Hudak, A.T., Boschetti, L., Falkowski, M.J., Greenberg, J.A., Anderson, J.W., Kliskey, A., Alessa, L., Keefe, R.F., Gosz, J.R., 2014. Remote sensing the vulnerability of vegetation in natural terrestrial ecosystems. Remote Sens. Environ. 154, 322-337. https://doi.org/10.1016/j.rse.2014.03.038

Smith, C.A.S., Meikle, J.C., Roots, C.F., 2004. Ecoregions of the Yukon Territory: Biophysical properties of Yukon landscapes. Agriculture and Agri-Food Canada, PARC Technical Bulletin No. 04-01, Summerland, British Columbia, 313 p

Song, C., Woodcock, C.E., Seto, K.C., Lenney, M.P., Macomber, S.A., 2001. Classification and Change Detection Using Landsat TM Data. Remote Sens. Environ. 75, 230-244. https://doi.org/10.1016/S0034-4257(00)00169-3

Splechtna, B.E., Dobrys, J., Klinka, K., 2000. Tree-ring characteristics of subalpine fir ( Abies lasiocarpa (Hook.) Nutt.) in relation to elevation and climatic fluctuations. Ann. For. Sci. 57, 89-100. https://doi.org/10.1051/forest:2000105

Stocker, T. F., Qin, D., Plattner, G. K., Tignor, M., Allen, S. K., Boschung, J., ...Midgley, P.M., 2013. Climate change 2013: The physical science basis. Intergovernmental panel on climate change, working group I contribution to the IPCC fifth assessment report (AR5). New York: Cambridge University Press.

Strong, W.L., Hills, L. V, 2013. Holocene migration of lodgepole pine ( Pinus contorta var. latifolia ) in southern Yukon, Canada. The Holocene 23, 1340-1349. https://doi.org/10.1177/0959683613484614

Sturm, M., Racine, C., Tape, K., 2001. Climate change. Increasing shrub abundance in the Arctic. Nature 411, 546-547. https://doi.org/10.1038/35079180

Sturm, M., Schimel, J., Michaelson, G., Welker, J.M., Oberbauer, S.F., Liston, G.E., Fahnestock, J., Romanovsky, V.E., 2005. Winter biological processes could help convert Arctic tundra to shrubland. Bioscience 55, 17-26. https://doi.org/10.1641/00063568(2005)055[0017:WBPCHC]2.0.CO;2

Sturrock, R.N., Frankel, S.J., Brown, A. V., Hennon, P.E., Kliejunas, J.T., Lewis, K.J., Worrall, J.J., Woods, A.J., 2011. Climate change and forest diseases. Plant Pathol. https://doi.org/10.1111/j.1365-3059.2010.02406.x

Sulla-Menashe, D., Friedl, M.A., Woodcock, C.E., 2016. Sources of bias and variability in longterm Landsat time series over Canadian boreal forests. Remote Sens. Environ. 177, 206219. https://doi.org/10.1016/j.rse.2016.02.041 
Tape, K., Sturm, M., Racine, C., 2006. The evidence for shrub expansion in Northern Alaska and the Pan-Arctic. Glob. Chang. Biol. 12, 686-702. https://doi.org/10.1111/j.13652486.2006.01128.x

Toutin, T., 2004. Geometric processing of remote sensing images: Models, algorithms and methods. Int. J. Remote Sens. 25, 1893-1924. https://doi.org/10.1080/0143116031000101611

Townshend, J.R.G., Justice, C.O., 1988. Selecting the spatial resolution of satellite sensors required for global monitoring of land transformations. Int. J. Remote Sens. 9, 187-236. https://doi.org/10.1080/01431168808954847

Trenberth, K.E., P.D. Jones, P. Ambenje, R. Bojariu, D. Easterling, A. Klein Tank, D. Parker, F. Rahimzadeh, J.A.Renwick, M. Rusticucci, B. Soden and P. Zhai., 2007. Observations: Surface and Atmospheric ClimateChange. In: Climate Change 2007: The Physical Science Basis. Contribution of Working Group I to theFourth Assessment Report of the Intergovernmental Panel on Climate Change [Solomon, S., D. Qin, M.Manning, Z. Chen, M. Marquis, K.B. Averyt, M. Tignor and H.L. Miller (eds.)]. Cambridge University Press, Cambridge, United Kingdom and New York, NY, USA.

Tsuyuzaki, S., Kushida, K., Kodama, Y., 2009. Recovery of surface albedo and plant cover after wildfire in a Picea mariana forest in interior Alaska. Clim. Change 93, 517-525. https://doi.org/10.1007/s10584-008-9505-y

Tucker, C.J., 1979. Red and photographic infrared linear combinations for monitoring vegetation. Remote Sens. Environ. 8, 127-150. https://doi.org/10.1016/00344257(79)90013-0

Tucker, C., Pinzon, J., Brown, M., Slayback, D., Pak, E., Mahoney, R., Vermote, E., El Saleous, N., 2005. An extended AVHRR 8-km NDVI dataset compatible with MODIS and SPOT vegetation NDVI data. Int. J. Remote Sens. 26, 4485-4498. https://doi.org/10.1080/01431160500168686

Turner, W., Rondinini, C., Pettorelli, N., Mora, B., Leidner, A.K., Szantoi, Z., Buchanan, G., Dech, S., Dwyer, J., Herold, M., Koh, L.P., Leimgruber, P., Taubenboeck, H., Wegmann, M., Wikelski, M., Woodcock, C., 2015. Free and open-access satellite data are key to biodiversity conservation. Biol. Conserv. 182, 173-176. https://doi.org/10.1016/j.biocon.2014.11.048

Turnquist R., 1987. Forest Insect and Disease Conditions 1987. Forestry Canada, Pacific and Yukon Region, Victoria BC. FIDS Report 88-07. 10 p.

USGS., 2016. Landsat missions timeline. https://landsat.usgs.gov/landsat-missions-timeline (accessed 13 November 2017). 
Van Asch, M., Visser, M.E., 2007. Phenology of Forest Caterpillars and Their Host Trees: The Importance of Synchrony. Annu. Rev. Entomol. 52, 37-55. https://doi.org/10.1146/annurev.ento.52.110405.091418

Vanonckelen, S., Lhermitte, S., Van Rompaey, A., 2013. The effect of atmospheric and topographic correction methods on land cover classification accuracy. Int. J. Appl. Earth Obs. Geoinf. 24, 9-21. https://doi.org/10.1016/j.jag.2013.02.003

Verbyla, D., 2011. Browning boreal forests of western North America. Environ. Res. Lett. 6, 41003. https://doi.org/10.1088/1748-9326/6/4/041003

Verbyla, D., 2015. Remote sensing of interannual boreal forest NDVI in relation to climatic conditions in interior Alaska. Environ. Res. Lett. 10, 125016. https://doi.org/10.1088/1748$9326 / 10 / 12 / 125016$

Vogelmann, J.E., Gallant, A.L., Shi, H., Zhu, Z., 2016. Perspectives on monitoring gradual change across the continuity of Landsat sensors using time-series data. Remote Sens. Environ. 185, 258-270. https://doi.org/10.1016/j.rse.2016.02.060

Wagner, D., Doak, P., 2013. Long-term impact of a leaf miner outbreak on the performance of quaking aspen. Can. J. For. Res. 43, 563-569. https://doi.org/10.1139/cjfr-2012-0486

Wagner, D., DeFoliart, L., Doak, P., Schneiderheinze, J., 2008. Impact of epidermal leaf mining by the aspen leaf miner (Phyllocnistis populiella) on the growth, physiology, and leaf longevity of quaking aspen. Oecologia 157, 259-267. https://doi.org/10.1007/s00442-0081067-1

Walker, X., Johnstone, J.F., 2014. Widespread negative correlations between black spruce growth and temperature across topographic moisture gradients in the boreal forest. Environ. Res. Lett. 9, 64016. https://doi.org/10.1088/1748-9326/9/6/064016

Wang, J., Rich, P.M., Price, K.P., Kettle, W.D., 2004. Relations between NDVI and tree productivity in the central Great Plains. Int. J. Remote Sens. 25, 3127-3138. https://doi.org/10.1080/0143116032000160499

Wang, J., Sammis, T.W., Gutschick, V.P., Gebremichael, M., Dennis, S.O., Harrison, R.E., 2010. Review of Satellite Remote Sensing Use in Forest Health Studies. Open Geogr. J. 3, 28-42. https://doi.org/10.2174/1874923201003010028

White, J.C., Wulder, M.A., Hobart, G.W., Luther, J.E., Hermosilla, T., Griffiths, P., Coops, N.C., Hall, R.J., Hostert, P., Dyk, A., Guindon, L., 2014. Pixel-Based Image Compositing for Large-Area Dense Time Series Applications and Science. Can. J. Remote Sens. 40, 192212. https://doi.org/10.1080/07038992.2014.945827

Wiens, J.A., Stenseth, N.C., Horne, B. Van, Ims, R.A., 1993. Ecological Mechanisms and Landscape Ecology. Oikos 66, 369. https://doi.org/10.2307/3544931 
Williams, P.A., Allen, C.D., Macalady, A.K., Griffin, D., Woodhouse, C.A., Meko, D.M., Swetnam, T.W., Rauscher, S.A., Seager, R., Grissino-Mayer, H.D., Dean, J.S., Cook, E.R., Gangodagamage, C., Cai, M., McDowell, N.G., 2012. Temperature as a potent driver of regional forest drought stress and tree mortality. Nat. Clim. Chang. 3, 292-297. https://doi.org/10.1038/nclimate 1693

Willstätter, R., \& Stoll A. (1913). Untersuchungen über die Assimilation der Kohlensäure. Springer, Berlin, Germany.

Wirth, C., Lichstein, J.W., Dushoff, J., Chen, A., Chapin, F.S., 2008. White spruce meets black spruce: Dispersal, postfire establishment, and growth in a warming climate. Ecol. Monogr. 78, 489-505. https://doi.org/10.1890/07-0074.1

Wookey, P.A., Aerts, R., Bardgett, R.D., Baptist, F., Brathen, K.A., Cornelissen, J.H.C., Gough, L., Hartely, I.P., Hopkins, D.W., Lavorel, S., Shaver, G.R., 2009. Ecosystem feedbacks and cascade processes: understanding their role in the responses of Arctic and alpine ecosystems to environmental change. Glob. Chang. Biol. 15, 1153-1172. https://doi.org/10.1111/j.1365-2486.2008.01801.x

Wulder, M.A., White, J.C., Goward, S.N., Masek, J.G., Irons, J.R., Herold, M., Cohen, W.B., Loveland, T.R., Woodcock, C.E., 2008a. Landsat continuity: Issues and opportunities for land cover monitoring. Remote Sens. Environ. 112, 955-969. https://doi.org/10.1016/j.rse.2007.07.004

Wulder, M.A., Butson, C.R., White, J.C., 2008b. Cross-sensor change detection over a forested landscape: Options to enable continuity of medium spatial resolution measures. Remote Sens. Environ. 112, 796-809. https://doi.org/10.1016/j.rse.2007.06.013

Wulder, M.A., Masek, J.G., Cohen, W.B., Loveland, T.R., Woodcock, C.E., 2012. Opening the archive: How free data has enabled the science and monitoring promise of Landsat. Remote Sens. Environ. 122, 2-10. https://doi.org/10.1016/j.rse.2012.01.010

Wylie, B., Rigge, M., Brisco, B., Murnaghan, K., Rover, J., Long, J., 2014. Effects of Disturbance and Climate Change on Ecosystem Performance in the Yukon River Basin Boreal Forest. Remote Sens. 6, 9145-9169. https://doi.org/10.3390/rs6109145

Wylie, B., Zhang, L., Bliss, N., Ji, L., Tieszen, L.L., Jolly, W.M., 2008. Integrating modelling and remote sensing to identify ecosystem performance anomalies in the boreal forest, Yukon River Basin, Alaska. Int. J. Digit. Earth 1, 196-220. https://doi.org/10.1080/17538940802038366

Yarie, J., 2008. Effects of moisture limitation on tree growth in upland and floodplain forest ecosystems in interior Alaska. For. Ecol. Manage. 256, 1055-1063. https://doi.org/10.1016/j.foreco.2008.06.022 
Young, N.E., Anderson, R.S., Chignell, S.M., Vorster, A.G., Lawrence, R., Evangelista, P.H., 2017. A survival guide to Landsat preprocessing. Ecology 98, 920-932.

https://doi.org/10.1002/ecy.1730

Youngblut, D., Luckman, B., 2008. Maximum June-July temperatures in the southwest Yukon over the last 300 years reconstructed from tree rings. Dendrochronologia 25, 153-166. https://doi.org/10.1016/j.dendro.2006.11.004

Yukon Energy, Mines and Resources, Forest Management Branch., 2009. 2009 Yukon Forest Health Survey. Forest Management Branch. Whitehorse, Yukon. http://www.emr.gov.yk.ca/forestry/forest_health_reports.html (accessed 13 November 2017)

Yukon Energy, Mines and Resources, Forest Management Branch., 2013. Yukon Vegetation Inventory Manual. Forest Management Branch. Whitehorse, Yukon. http://www.emr.gov.yk.ca/forestry/inventory_analysis.html (accessed 13 November 2017)

Yukon Energy, Mines and Resources, Forest Management Branch., 2014. 2014 Yukon Forest Health Survey. Forest Management Branch. Whitehorse, Yukon. http://www.emr.gov.yk.ca/forestry/forest_health_reports.html (accessed 13 November 2017)

Yukon Energy, Mines and Resources, Forest Management Branch., 2018. Yukon Forest Planning, Whitehorse and Southern Lakes. http://yukonforestplanning.ca (accessed 13 January 2018)

Zhang, H.K., Roy, D.P., 2016. Landsat 5 Thematic Mapper reflectance and NDVI 27-year time series inconsistencies due to satellite orbit change. Remote Sens. Environ. 186, 217-233. https://doi.org/10.1016/j.rse.2016.08.022

Zhang, Y., Peng, C., Li, W., Fang, X., Zhang, T., Zhu, Q., Chen, H., Zhao, P., 2013. Monitoring and estimating drought-induced impacts on forest structure, growth, function, and ecosystem services using remote-sensing data: recent progress and future challenges. Environ. Rev. 21, 103-115. https://doi.org/10.1139/er-2013-0006

Zhou, L., Tucker, C.J., Kaufmann, R.K., Slayback, D., Shabanov, N. V., Myneni, R.B., 2001. Variations in northern vegetation activity inferred from satellite data of vegetation index during 1981 to 1999. J. Geophys. Res. Atmos. 106, 20069-20083. https://doi.org/10.1029/2000JD000115 